FHWA/IN/JTRP-2008/1

Final Report

ORIGIN-DESTINATION TOOLS FOR DISTRICT OFFICES

Jon D. Fricker

Maria Martchouk

August 2009 
Final Report

FHWA/IN/JTRP-2008/1

\title{
Origin-Destination Tools for District Offices
}

\author{
by \\ Jon D. Fricker \\ Professor \\ and \\ Maria Martchouk \\ Graduate Research Assistant \\ School of Civil Engineering \\ Purdue University \\ Joint Transportation Research Program \\ Project No. C-36-54JJJ \\ File No. 3-3-62 \\ SPR-3095 \\ Prepared in Cooperation with the \\ Indiana Department of Transportation and the \\ U.S. Department of Transportation \\ Federal Highway Administration
}

The contents of this report reflect the views of the author who is responsible for the facts and the accuracy of the data presented herein. The contents do not necessarily reflect the official views or policies of the Indiana Department of Transportation or the Federal Highway Administration at the time of publication. This report does not constitute a standard, specification, or regulation.

\author{
Purdue University \\ West Lafayette, Indiana 47907
}

August 2009 
TECHNICAL REPORT STANDARD TITLE PAGE

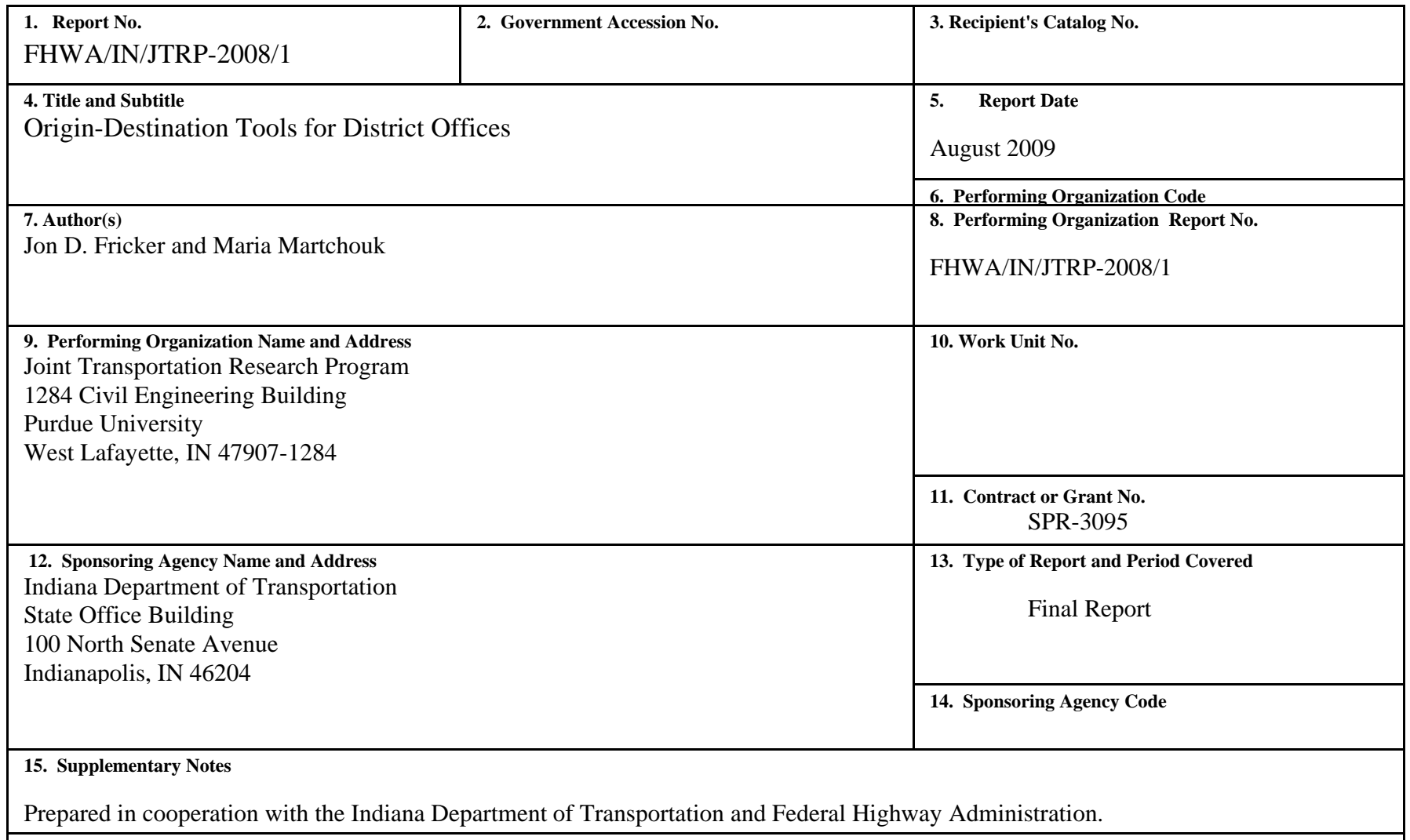

\section{Abstract}

Understanding through trip patterns is crucial when making decisions concerning a traffic diversion strategy, such as whether to build a highway to bypass a city. While conducting a vehicle license plate origin-destination survey may be the most accurate way to estimate through trip patterns, many small communities may be unable to bear this cost. Thus, a simple and affordable sketch planning tool to estimate through trip movements would be useful. Three through trip estimation methods that have been used or published are Modlin's method, Anderson's method, and subarea analysis. Subarea analysis, while an effective tool, requires personnel with knowledge of modeling software, as well as a license for that software. Hence, subarea analysis may be of limited use to small cities and DOT district offices. Anderson and Modlin methods on the other hand are simpler to implement. However, these methods require some data that are not routinely collected, use parameters that can be highly subjective, and rely on calculations that may distort the results. To address some of the shortcomings of the existing methods, a logit-based external trip estimation method was created that had strong statistical justification. Evaluation of the logit model using small cities in Indiana yielded results that are usually better than Modlin's and Anderson's methods. The logit model is readily implemented in a spreadsheet and requires only two input variables. When subarea analysis using modeling software is not feasible, the logit model has been shown to produce good estimates of through trips.

17. Key Words
through trips, external trips, origin-destination matrix estimation.

18. Distribution Statement

No restrictions. This document is available to the public through the National Technical Information Service, Springfield, VA 22161

\footnotetext{
19. Security Classif. (of this report)

Unclassified
}

\author{
20. Security Classif. (of this page)
}

Unclassified

\begin{tabular}{|c|c|}
\hline 21. No. of Pages & 22. Price \\
120 & \\
\hline
\end{tabular}




\section{TABLE OF CONTENTS}

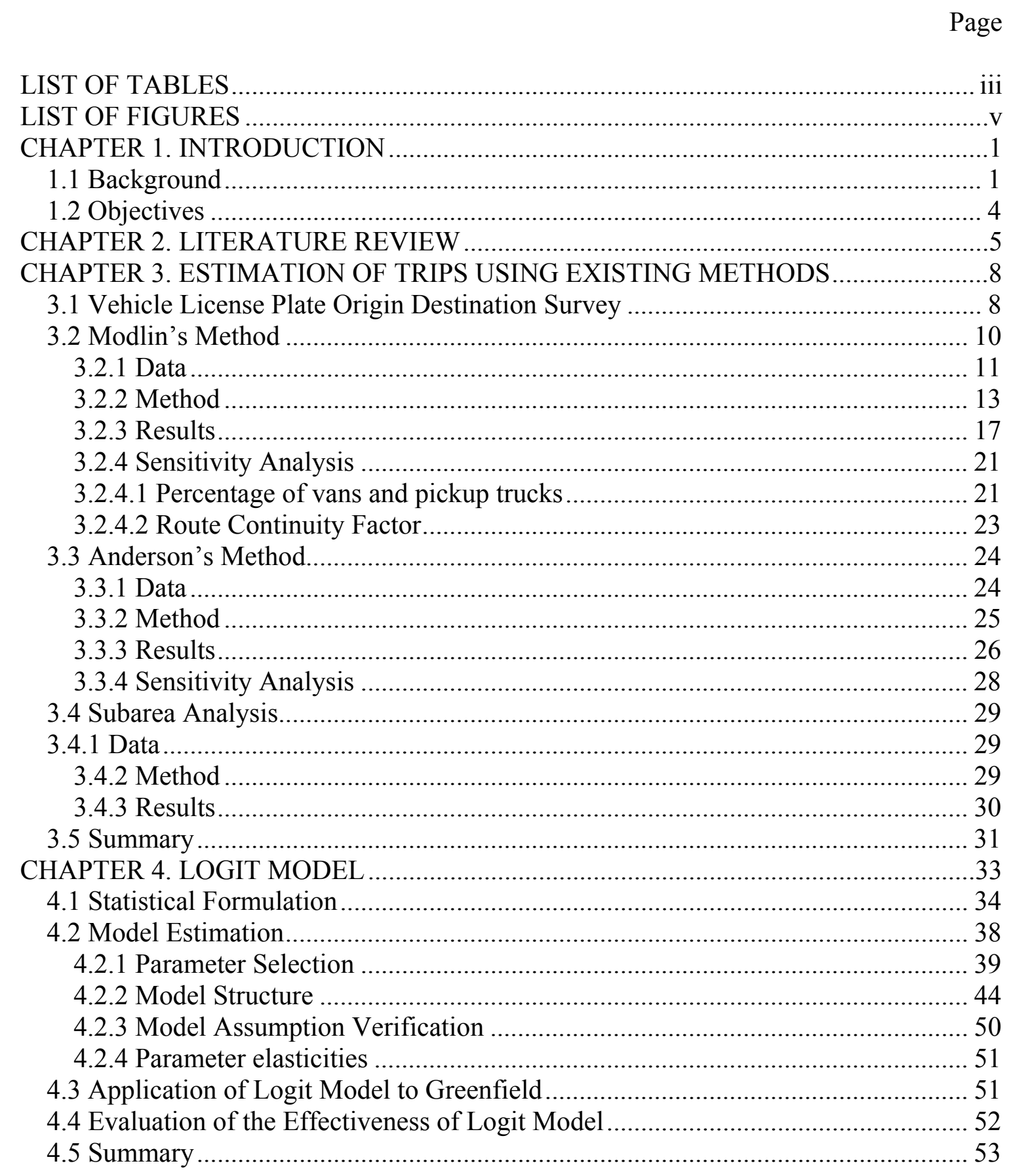


CHAPTER 5. APPLICATION OF THE ESTIMATION METHODS LAPORTE ..........54

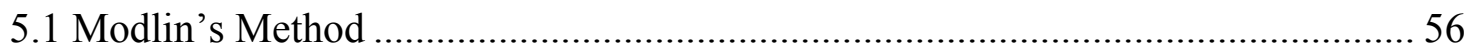

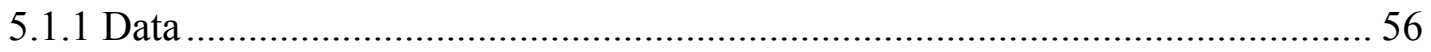

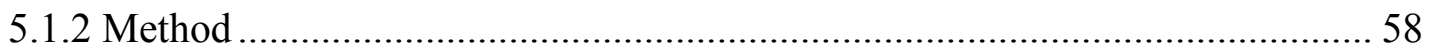

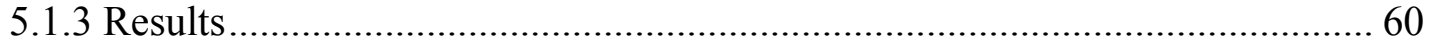

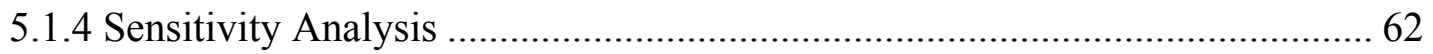

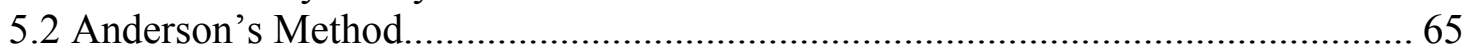

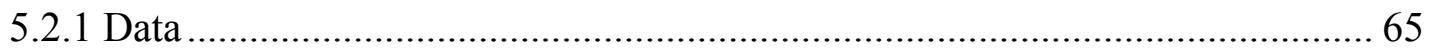

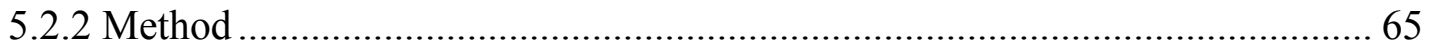

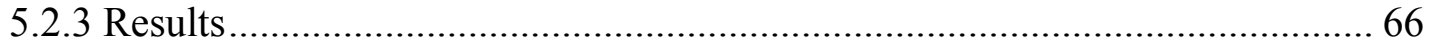

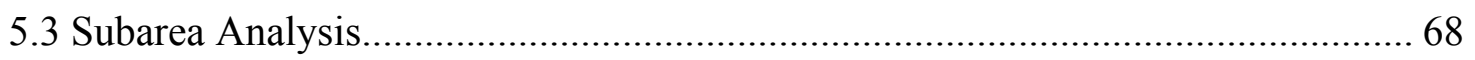

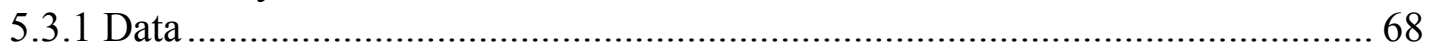

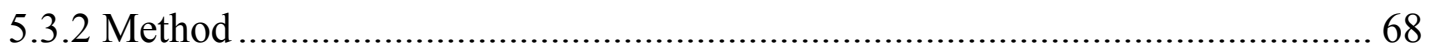

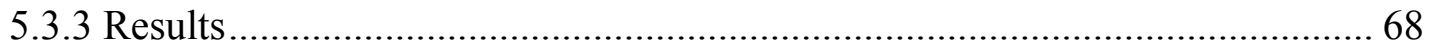

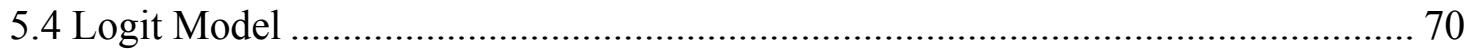

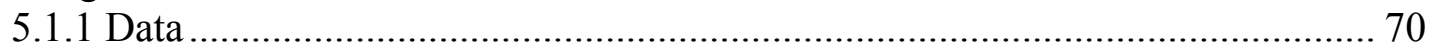

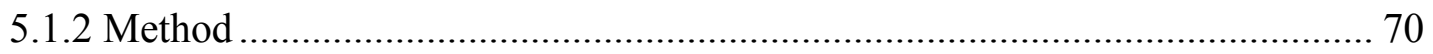

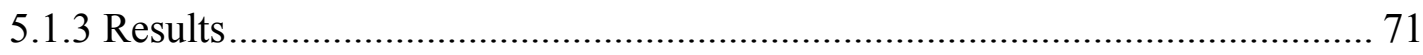

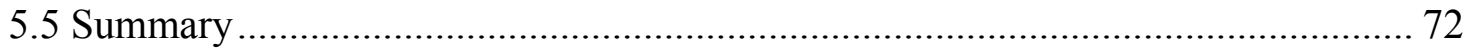

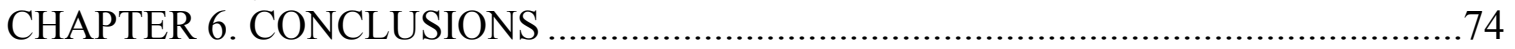

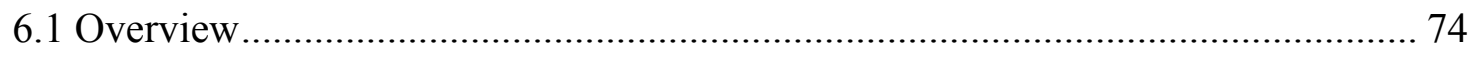

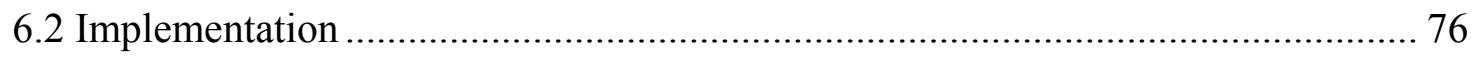

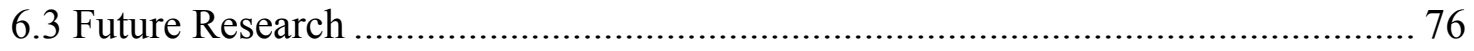

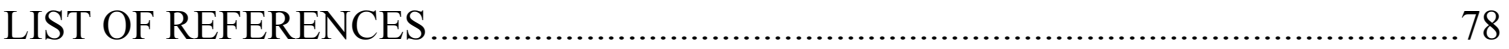

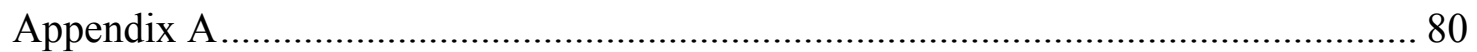

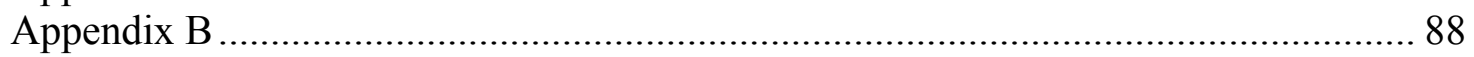

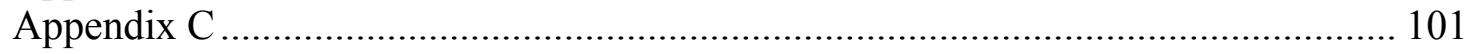

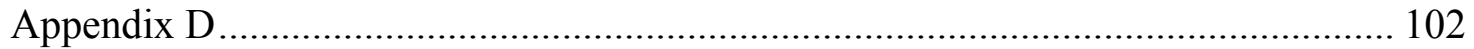

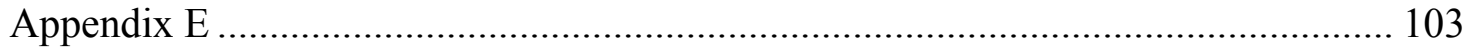




\section{LIST OF TABLES}

Table

Page

Table 1.1- Example of a through trip table* 3

Table 3.1- Greenfield External- External (EE) and External- Internal (EI) Trips ............ 10

Table 3.2- Greenfield External Station Daily Counts ................................................ 11

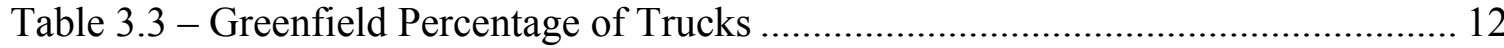

Table 3.4- Greenfield Route Continuity Factor ........................................................... 13

Table 3.5 -Greenfield Cumulative Through Trips using Modlin's Method..................... 14

Table 3.6 - Greenfield Base Through Trip Percentages using Modlin's Method............ 15

Table 3.7 - Greenfield Normalized Through Trip Percentages using Modlin's

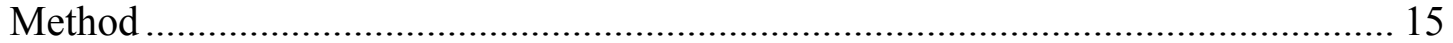

Table 3.8 - Greenfield Base Trip Distribution using Modlin's Method.......................... 16

Table 3.9- Greenfield Symmetrical Trip Distribution using Modlin's Method................ 16

Table 3.10- Greenfield EE and EI Trip Distribution using Modlin's Method.................. 18

Table 3.11- Greenfield EE and EI Trip Percentages using Modlin's Method................. 19

Table 3.12- Greenfield Differences between Actual and Estimated Trips using

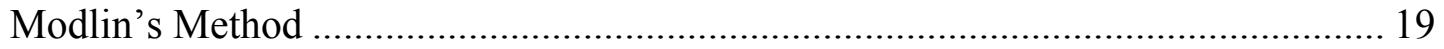

Table 3.13- Greenfield Percent Error between Actual and Estimated Trips using

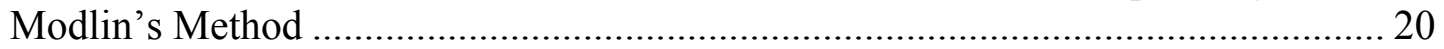

Table 3.14- Greenfield Through Trip Percentages with PPSi= 24\% using Modlin's

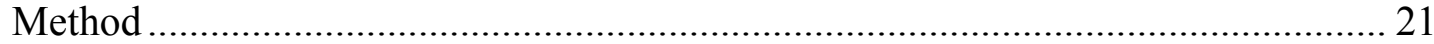

Table 3.15- Greenfield Through Trip Distribution with PPSi=24\% using Modlin's

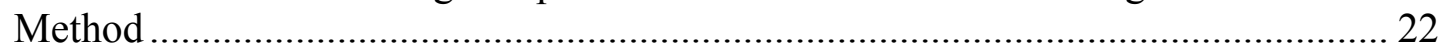

Table 3.16- Greenfield Through Trip Percentages with PPSi $=40 \%$ using Modlin's

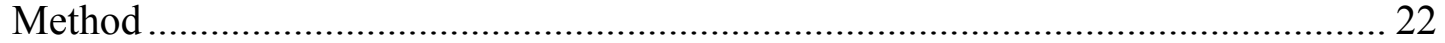

Table 3.17- Greenfield Through Trip Distribution with PPSi=40\% using Modlin's

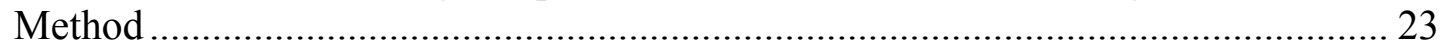

Table 3.18 - Greenfield Through Trip Distribution with Different Route

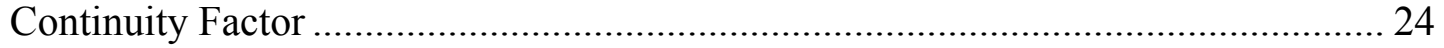

Table 3.19- Greenfield Base Trip Percentages using Anderson's Method....................... 26

Table 3.20- Greenfield EE and EI trip Distribution using Anderson's Method ............... 26

Table 3.21- Greenfield EE and EI Trip Percentages using Anderson's Method .............. 26

Table 3.22- Greenfield Differences between Estimated and Actual Trips using

Anderson's Method

Table 3.23- Greenfield Differences between the Percentages of Estimated and

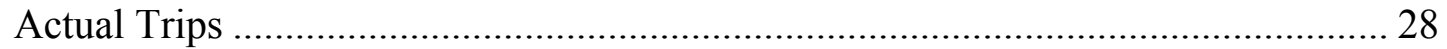

Table 3.24- Greenfield Trip Distribution with a Different Route Continuity Factor ....... 28

Table 3.25- Greenfield EE and EI Trips using Subarea Analysis................................. 30

Table 3.26- Greenfield Trip Percentages using Subarea Analysis ................................ 31

Table 3.27- Greenfield Errors Arising from using Different Models............................. 32 
Table 4.1- Indiana Cities Used in the Estimation of the Logit Model ............................ 36

Table 4.2- Employment Data ................................................................................... 44

Table 4.3- Logit Model with all Variables Included................................................... 45

Table 4.4- Logit Model with only Relevant Variables ............................................... 48

Table 4.5- Two-Utility Function Logit Model with all Variables Included 48

Table 4.6- Logit Model with Two Utility Functions ..................................................... 49

Table 4.7- Greenfield Through Trip Distribution using Logit Model ............................. 52

Table 4.8- Greenfield Through Trip Percentages using Logit Model ............................. 52

Table 4.9- Model Performance Comparison using Greenfield Data ............................... 53

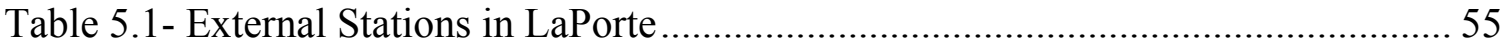

Table 5.2- LaPorte External-External and External-Internal Trip Matrix ....................... 55

Table 5.3- LaPorte EE and EI Trip Percentages ........................................................... 55

Table 5.4- LaPorte External Station Daily Counts ....................................................... 56

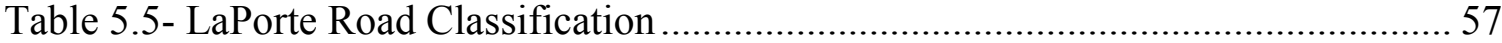

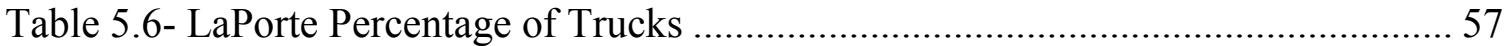

Table 5.7- LaPorte Route Continuity Factor.................................................................... 58

Table 5.8- LaPorte Through Trips using Modlin's Method ............................................ 59

Table 5.9- LaPorte Through Trip Percent Distribution for LaPorte using Modlin's

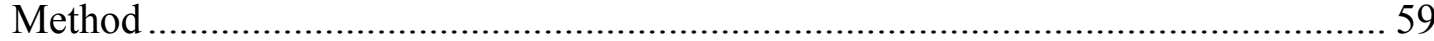

Table 5.10- LaPorte Through Trip Distribution for LaPorte using Modlin's

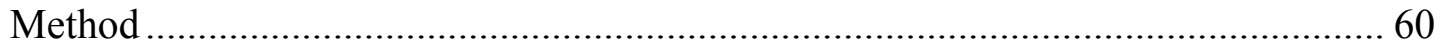

Table 5.11- LaPorte Through and External-Internal Trip Distribution using

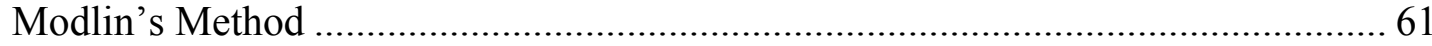

Table 5.12- LaPorte Through and EI Trip Percentages using Modlin's Method ............ 61

Table 5.13- LaPorte EE and EI Trip Distribution with PPSi=24\% using Modlin's

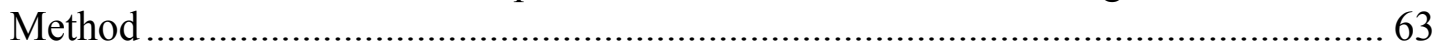

Table 5.14- LaPorte EE and EI Trip Percentages with PPSi=24\% using Modlin's

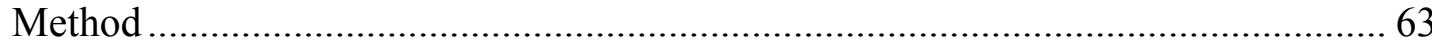

Table 5.15- LaPorte EE and EI Trip Distribution with PPSi=40\% using Modlin's Method

Table 5.16- LaPorte EE and EI Trip Percentages with PPSi=40\% using Modlin's

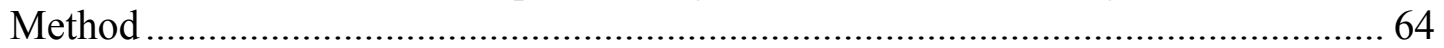

Table 5.17- LaPorte Base Trip Percentages using Anderson's Method ............................ 65

Table 5.18- LaPorte Symmetrical Trip Distribution using Anderson's Method .............. 66

Table 5.19- LaPorte Balanced EE and IE Trip Distribution using Anderson's

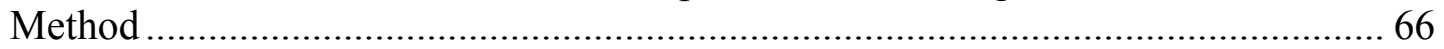

Table 5.20- LaPorte EE and IE Trip Percentages using Anderson's Method .................. 67

Table 5.21- LaPorte Percent Error between Actual and Predicted Trips using

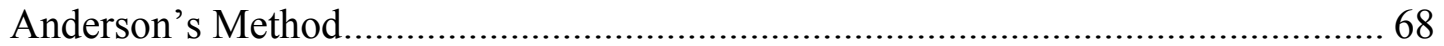

Table 5.22- LaPorte Base EE and EI Trip Distribution using Subarea Analysis ............ 69

Table 5.23- LaPorte Balanced EE and EI Trip Percentages using Subarea Analysis....... 69

Table 5.24- LaPorte EE and EI Trip Distribution using Logit Model ........................... 71

Table 5.25- LaPorte EE and EI Trip Percentages using Logit Model ............................ 71

Table 5.26- LaPorte Errors Arising from Different OD Estimation Methods ................. 73 


\section{LIST OF FIGURES}

$\begin{array}{ll}\text { Figure } & \text { Page }\end{array}$

Figure 1.1- Cordon line and external stations for Winamac city .................................. 2

Figure 3.1- Greenfield Study Area............................................................................ 9

Figure 3.2- Greenfield Predicted versus Actual Trips using Modlin's Method ............... 18

Figure 3.3- Greenfield Trips Predicted by Anderson's Method versus Actual Trips....... 27

Figure 3.4- Greenfield Predicted versus Actual Trips using Subarea Analysis............... 31

Figure 4.1 - Locations of Cities Used for Logit Model Calibration ................................. 37

Figure 4.2- Example of a Continuous Route .................................................................. 42

Figure 4.3- Nested Logit Structure ............................................................................ 51

Figure 4.4- Logit Model Trips Predicted by Logit Model versus Actual Trips................ 53

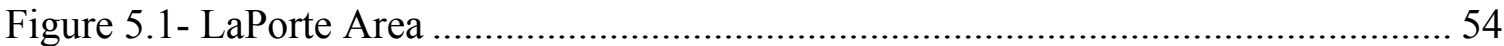

Figure 5.2 - LaPorte Predicted versus Actual Through Trips .......................................... 62

Figure 5.3- LaPorte Predicted versus Actual Through Trips using Anderson's

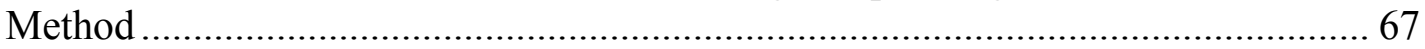

Figure 5.4- LaPorte Predicted versus Actual Trips using Subarea Analysis ................... 70

Figure 5.5- LaPorte Predicted versus Actual Trips using Logit Model ........................... 72 


\section{CHAPTER 1. INTRODUCTION}

\subsection{Background}

Transportation planning is a resource consuming, sometimes frustrating and never simple process. However, before any major investment is made, there is a need to evaluate the existing situation as well as the possible impacts of the investment. One type of decision made on a regular basis all across the country concerns through movements of cars in a city. These decisions, which may include erecting a bypass or rerouting truck traffic, require understanding of the traffic movement in and out of the city. In order to calculate these trips, first the study area is outlined by drawing a cordon line around the community of interest. For example, Figure 1.1 shows the city of Winamac with the cordon line drawn around the heavily populated area. Through trips can then be determined by observing vehicles entering and leaving the city at stations located on the cordon line along major routes. (See stations A through $\mathrm{E}$ in Figure 1.1.) 


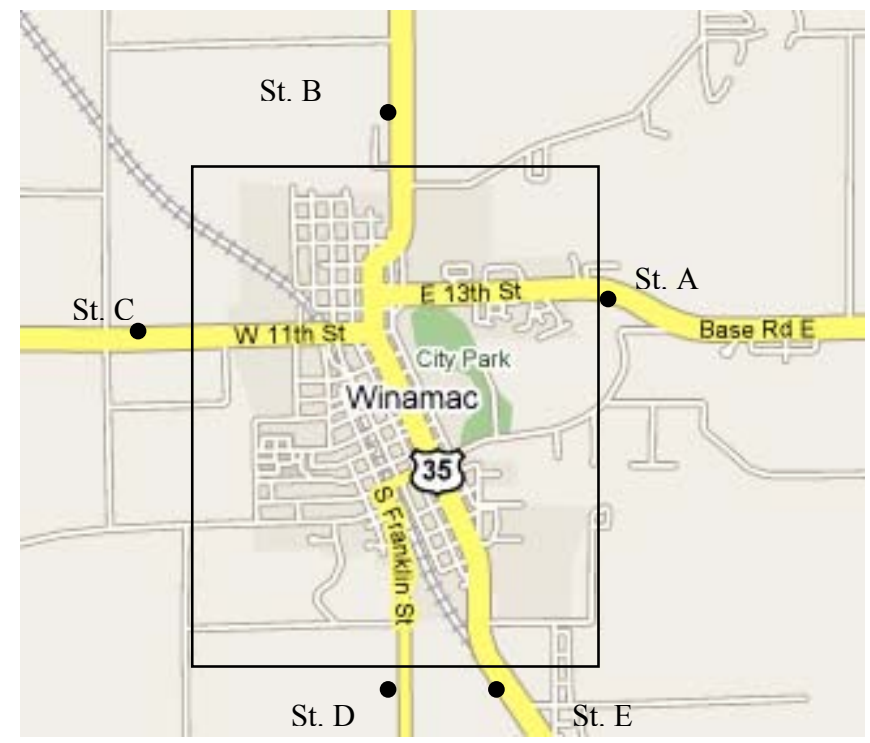

Figure 1.1- Cordon line and external stations for Winamac city

The observed trips are then classified into external-external (through) and externalinternal trips. The through trips proceed through the city enroute to another destination and are characterized by a vehicle entering the city at one cordon station and exiting it at another within a brief period of time. External-internal trips, on the other hand, occur when a vehicle has a destination in the city and is seen entering the city, spending some time within the community and only then exiting. The through trips and external-internal trips are usually documented in an origin-destination (OD) table, such as one shown in Table 1.1. Ideally, this table is produced by determining the origin and destination of every car that passes through the city, to determine whether the trip was external-internal or a through trip. However, this process would be extremely tedious and most likely infeasible. A simpler way to estimate the real trip table is needed. There are several different methods for synthesizing a trip table, including a vehicle license plate origindestination survey, roadside surveys, Modlin's method (Martin and McGuckin, 1998) for generating through trips, and even basic gravity models (Meyer and Miller, 2001). In large metropolitan areas, origin-destination surveys can also be done through phone interviews asking the respondents to describe their travel patterns during a set period of 
time (usually one week). The choice of the methodology often depends on the budget of the community in question.

Table 1.1- Example of a through trip table*

\begin{tabular}{|l|r|r|r|r|r|}
\hline & \multicolumn{7}{|c|}{ Destinations } \\
\hline Origin & A & B & C & D & E \\
\hline A & 1000 & 100 & 200 & 15 & 500 \\
\hline B & 100 & 1500 & 250 & 50 & 100 \\
\hline C & 200 & 250 & 900 & 70 & 0 \\
\hline D & 15 & 50 & 70 & 600 & 80 \\
\hline E & 500 & 100 & 0 & 80 & 1200 \\
\hline
\end{tabular}

*Note: This table is used as an example and does not represent the actual through trip table for the city of Winamac

The most common procedure used to analyze the traffic is an origin-destination vehicle license plate study, which monitors the traffic at all the major entrance points into the community. The origin-destination survey starts off by placing external stations on all the major routes that enter the city in question, just outside the study area (Figure 1.1). License plates of all vehicles entering and exiting the community are recorded, either using video or audio recording methods for a period of time. This time period often includes $\mathrm{AM}$ and PM peaks or is sometimes extended to a full day. In addition to recording the license plates, the average annual daily traffic is measured at all the cordon stations. Once the license plates have been captured, a matching procedure is used to determine the number of through (external-external) trips and the number of externalinternal trips. Trips classified as external-external are those that enter the city and exit it within a period of time that it would take a vehicle to travel between the entrance and exit points. All the other trips are assumed to have a destination within the city and are thus treated as external-internal trips. After calculating the number of external-external and external-internal trips for each pair of stations, this number is expanded to the daily total, based on the average annual daily traffic (AADT). A demonstration of this procedure is included in section 3.1 for the city of Greenfield. 
An origin-destination survey, while being an effective tool in making planning decisions, is financially demanding. While the cost depends on the size of the community, even for smaller ones, it can cost more than $\$ 50,000$ and take more than a month to produce the final report (Transformation Systems Inc., 2001). Smaller communities that cannot undertake vehicle license plate surveys still need to respond to the bypass requests issued by citizen groups. As a result, some of them rely on conventional trip distribution theory in the form of a gravity model or factoring an existing trip table, both of which have been shown to be error prone methods (Horowitz and Patel, 1999). What these communities need is a quick response tool for evaluating through trips. If this tool indicates the need for a bypass, then the funds for a vehicle license plate survey could be justified. The tool proposed in this study will provide a simple way to estimate the percentage of through trips based on available information, such as AADT, route geometry, percentage of trucks and other factors.

\subsection{Objectives}

The aim of this research is to evaluate existing tools that can be used to provide through trip information for small communities in Indiana and to improve any deficiencies that these methods may have. This goal will be achieved by comparing the results of existing methods to the outcomes of origin-destination surveys conducted in three cities in Indiana. The first city that each of the models will be tested on is Greenfield, Indiana. An improved through trip estimation technique will also be

proposed. Following this, the methods will be used to estimate the through trips for the city of LaPorte. 


\section{CHAPTER 2. LITERATURE REVIEW}

External trips comprise a small portion of the total traffic within the city. As a result, the majority of research focuses on internal trips that affect congestion within the community and motivate most transportation system expansions. Therefore, the amount of research that has been conducted in the area of estimating through trips is limited. One of the most commonly used methods to evaluate the through trips was developed by D. G. Modlin and was later updated and published in NCHRP Report 365 (Martin and McGuckin, 1998). This method consists of two steps: (1) estimation of through trips at each cordon station and (2) distribution thereof between pairs of stations. Both steps use linear regression equations estimated from small communities in North Carolina. The model used in the first step of this method uses the following parameters:

- functional classification of the highway (interstate, principal arterial or minor arterial)

- $\mathrm{AADT}$

- percentage of trucks

- $\quad$ population of the area

The second step then uses the estimated percentage of through trips evaluated in the first part to distribute trips between pairs of cordon stations based on:

- functional classification

- $\mathrm{AADT}$ of the destination station

- route connectivity factor

The result of this method is a synthesized origin-destination trip table for all the selected cordon stations. The exact equations used in this method will be discussed and 
applied in section 3.1. Modlin's method is simple; however, it lacks theoretical justification as will be shown in section 4. In addition, one of the factors (route continuity) that has a large impact on the resulting trip distribution is not well defined. As a result, the planner may not be able to select the appropriate value of route continuity parameter when applying this method.

Another method for estimating through trips in a community is Anderson's model (Anderson et al., 2006). Although it has not seen widespread use, this model aims to improve Modlin's method by incorporating the effects of neighboring communities. This is accomplished by including a variable that reflects the presence of a nearby major center. Anderson's methodology was developed based on vehicle license plate surveys conducted in 7 cities in Alabama. The results of the surveys were used to develop a linear regression model that could be used to predict the external-external as well as externalinternal trips. Anderson's method differs from Modlin's in that his method only consists of one step and evaluates the external-internal trips in addition to through trips. The variables used in the model include AADT, presence of a nearby major center, route continuity and internal-external factor. Overall, Anderson's method suffers from similar deficiencies as Modlin's; the choice of linear regression is not justified and the choice of route continuity parameter is not clear.

The third method that has been used extensively, both to estimate the through trips as well as the internal trips within an area of interest, is subarea analysis performed in TransCAD. This method may be considered most reliable because the results are based on macro analysis performed on an actual model of a network. This type of analysis begins with the four-step process: trip generation, trip distribution, modal split, and trip assignment on a statewide level. Then, the subarea of interest is delineated within the state network and trip assignment is performed again, this time keeping track of vehicles entering and exiting the delineated area. The results of this method include a trip table with traffic counts between all the cordon stations. While perceived as effective by most people, some claim that when a small area is extracted from a statewide network, the 
results may not be entirely reliable. Another issue that arises with this model is the need for personnel with specialized knowledge of TransCAD as well as the high price of the software package.

The last type of model that has been used to generate through trips was developed by Horowitz and Patel (1999). This model attempts to integrate the geography of the region in the model. The basis of this method lies in definition of the catchment areas and barriers to travel (e.g., a body of water or mountains). This model is difficult to apply because of the need for numerical integration and the complex model structure. Furthermore, this method may not be advantageous when the area has no significant barriers to travel, as is the case with most cities in Indiana. 


\section{CHAPTER 3. ESTIMATION OF TRIPS USING EXISTING METHODS}

\subsection{Vehicle License Plate Origin Destination Survey}

In order to evaluate the effectiveness of different methods used to predict through trips and external-internal trips, a dataset containing the results of a vehicle license plate survey was needed. One such dataset was available for the city of Greenfield. The matrix containing the trips going through the city (with no stops within the community) as well as those with one trip end within the city was obtained from a vehicle license plate origindestination survey. The survey was performed and documented by Paul I. Cripe Inc. as a part of the Environmental Assessment of the SR-9 corridor (Paul I. Cripe Inc., 2004). The analysis area considered for the purposes of the study is outlined in Figure 3.1.

The external stations, shown as black dots in Figure 3.1, include: 2 located on SR-9 (first at the intersection with Maxwell and second just North of 100S), 2 on US-40 (one at the intersection with CR-75W and the second just West of 400E), 1 on the eastbound I-70 off-ramp at SR-9, 1 on the westbound I-70 off-ramp, 1 on the I-70 eastbound on-ramp and 1 on the I-70 westbound on-ramp. 


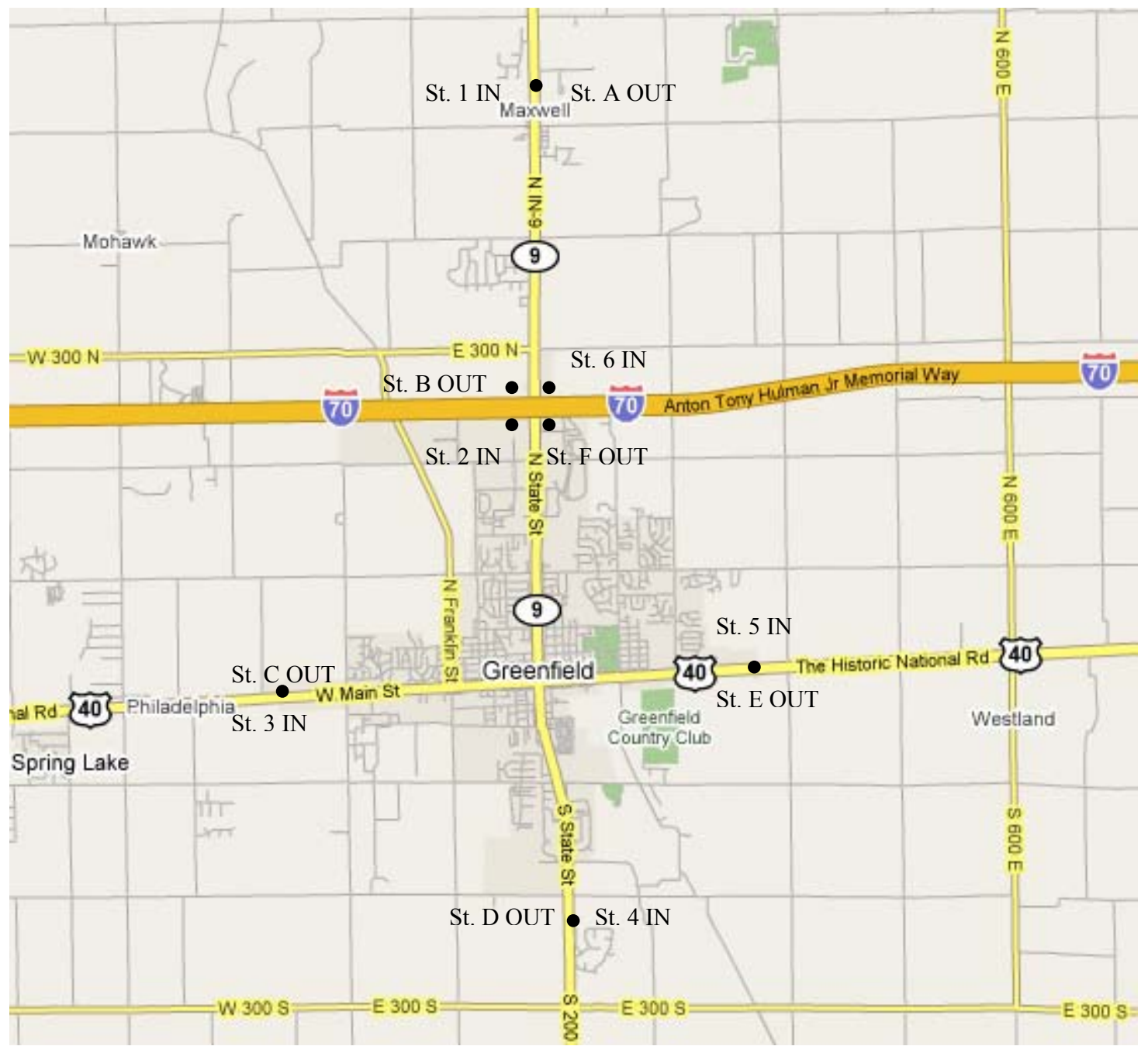

Figure 3.1- Greenfield Study Area

The trip data was collected at the 12 external stations, A through F and 1 through 6, during two 2.5-hour periods (AM and PM peaks) on August 21, 2001. After the data was collected, it was expanded to the daily trips based on the assumption that the through trip percentage calculated during the 5-hour period is the same as that for the 24 hours. This assumption can be justified by the fact that people traveling between two external stations during the AM peak will travel in the opposite direction during the PM peak and thus the average through trip percentage at each station will balanced. In order to determine the total daily through trips, the average through trip percentage for each pair 
of stations was multiplied by the AADT and balanced using the Biproportional balancing method. The resulting origin-destination matrix is shown in Table 3.1. This matrix was then assumed to represent the true vehicle flow and was used for comparison with the results produced by the different estimation methods.

Table 3.1- Greenfield External- External (EE) and External- Internal (EI) Trips

\begin{tabular}{|c|c|c|c|c|c|c|c|}
\hline & $\begin{array}{c}\text { SR-9 N } \\
\text { (A OUT) }\end{array}$ & $\begin{array}{c}\text { I-70 W } \\
\text { (B OUT) }\end{array}$ & $\begin{array}{c}\text { US-40 } \\
\text { (C OUT) }\end{array}$ & $\begin{array}{c}\text { SR-9 S } \\
\text { (D OUT) }\end{array}$ & $\begin{array}{c}\text { US-40 E } \\
\text { (E OUT) }\end{array}$ & $\begin{array}{c}\text { I-70 E } \\
\text { (F OUT) }\end{array}$ & Total ext \\
\hline $\begin{array}{c}\text { SR-9 N } \\
(1 \text { IN) }\end{array}$ & 4004 & 506 & 71 & 242 & 25 & 75 & 919 \\
\hline $\begin{array}{c}\text { I-70 W } \\
\text { ramp (2 IN) }\end{array}$ & 689 & 7254 & 80 & 97 & 128 & 0 & 994 \\
\hline $\begin{array}{c}\text { US-40 W } \\
(3 \text { IN) }\end{array}$ & 79 & 49 & 6972 & 61 & 351 & 24 & 564 \\
\hline $\begin{array}{c}\text { SR-9 S } \\
(4 \text { IN) }\end{array}$ & 406 & 146 & 58 & 3472 & 53 & 47 & 710 \\
\hline $\begin{array}{c}\text { US-40 E } \\
(5 \text { IN) }\end{array}$ & 80 & 151 & 337 & 71 & 4768 & 9 & 648 \\
\hline $\begin{array}{c}\text { I-70 E ramp } \\
(6 \text { IN) }\end{array}$ & 153 & 0 & 21 & 86 & 6 & 2528 & 266 \\
\hline \begin{tabular}{c} 
Total ext \\
\hline
\end{tabular} & 1407 & 852 & 567 & 557 & 563 & 155 & 4101 \\
\hline
\end{tabular}

\subsection{Modlin's Method}

Modlin's method, used to predict the external trips through a small urban center, is based on a linear regression model (Martin and McGuckin, 1998). In the first step the percentage of external trips are predicted for each cordon station as a function of the road class, AADT, percentage of trucks, percentage of vans and pickups and population within the cordon line. The second step of the process uses the external trip percentages predicted in the first step as well as route continuity factors to distribute the through trips between pairs of external stations.

One problem with the method as published in the NCHRP report is the overestimation of the number of external trips due to double counting. This issue occurs in the last step of the model when the trips are being distributed in the matrix; and it is 
balanced to reflect the total external trips at each cordon station. Because the AADT used to determine the external trips is two-way AADT, all external trips that originate and terminate at each external station should be included in the total number of external trips. However, in the method all the trips originating at station A sum to the external trips at station A and all the trips destined to station A also sum to the external trips. This discrepancy can be addressed by dividing the number of external trips by two and balancing the trips originating at a station to this number and the trips destined to this station to the same number.

\subsubsection{Data}

The data required for Modlin's analysis includes the AADT at each station, road class, percentage of trucks, percentage of vans and pickups, population and route continuity factors.

\section{AADT}

The average annual daily traffic counts were obtained from the Environmental Assessment of SR-9 corridor (Paul I. Cripe Inc., 2004). These were collected at all 12 external stations over the course of 24 hours during the same day the vehicle license plate survey was conducted. The AADT counts are summarized in Table 3.2.

Table 3.2- Greenfield External Station Daily Counts

\begin{tabular}{|l|l|l|l|l|l|l|}
\hline Station & SR-9 N & I-70 W & US-40 W & SR-9 S & US-40 E & I-70 E \\
\hline AADT & 5004 & 8430 & 7223 & 4168 & 4922 & 2879 \\
\hline
\end{tabular}

\section{Road Class}

Modlin's method requires identifying the roads as one of three classes: interstate, principal arterial, or minor arterial. This classification is assumed to apply to a state or national network. Thus the roads within the study area, which are all either US highways or State Routes, were assigned to the principal arterial class. 


\section{Percentage of Trucks}

The percentage of trucks was obtained from the report by Paul I. Cripe Inc. and was based on the vehicle classification results (Table 3.3) (Paul I. Cripe Inc. 2004).

Table 3.3 - Greenfield Percentage of Trucks

\begin{tabular}{|l|r|r|r|r|r|r|}
\hline & \multicolumn{1}{|l|}{ SR-9 N } & I-70 W & US-40 W & \multicolumn{1}{l|}{ SR-9 S } & US-40 E & \multicolumn{1}{l|}{ I-70 E } \\
\hline Trucks & 655 & 1165 & 997.5 & 602.5 & 675.5 & 399 \\
\hline Total & 5004 & 8430 & 7223 & 4168 & 4922 & 2879 \\
\hline \% Trucks & $13.1 \%$ & $13.8 \%$ & $13.8 \%$ & $14.5 \%$ & $13.8 \%$ & $13.8 \%$ \\
\hline
\end{tabular}

\section{Percentage of Vans and Pickups}

The data concerning the number of vans and pickups was not available from the Environmental Assessment of the SR-9 corridor. Thus, a value obtained from the WeighIn-Motion sensors (WIM) on the interstates in Indiana was obtained. This data indicated that the percentage of vans and pickup trucks varied annually between $24 \%$ and $40 \%$ with an average value of $31 \%$. The average value was used in the initial analysis and values of $24 \%$ and $40 \%$ are considered in the sensitivity analysis section.

\section{Population}

The population of the area within the cordon line was assumed to be the total Greenfield population as determined in the 2000 Census. This value was 16,654 people.

\section{Route Continuity Factor}

The route continuity factor, which is an indicator variable, was set to 1 for a pair of stations lying on the same route. Furthermore, the route continuity factor of 1 was assigned to pairs of stations where the origin was an interstate ramp from I-70 to SR-9 and the destination was located on SR-9. The full matrix of route continuity factors is described below (Table 3.4). 
Table 3.4- Greenfield Route Continuity Factor

\begin{tabular}{|l|r|r|r|r|r|r|}
\hline & SR-9 N & I-70 W & US-40 W & SR-9 S & US-40 E & I-70 E \\
\hline SR-9 N & 0 & 0 & 0 & 1 & 0 & 0 \\
\hline I-70 W ramp & 1 & 0 & 0 & 1 & 0 & 0 \\
\hline US-40 W & 0 & 0 & 0 & 0 & 1 & 0 \\
\hline SR-9 S & 1 & 0 & 0 & 0 & 0 & 0 \\
\hline US-40 E & 0 & 0 & 1 & 0 & 0 & 0 \\
\hline I-70 E ramp & 1 & 0 & 0 & 1 & 0 & 0 \\
\hline
\end{tabular}

\subsubsection{Method}

The first step is to calculate the percentage of external trips at each origin station using equation 3.1

$Y_{i}=76.76+11.22 * I-25.74 * P A-42.18 * M A+0.00012 * A D T_{i}+0.59 * P T K S_{i}-$

$0.48 * P P S_{i}-0.000417 * P O P$

Eq.3.1

where:

$\mathrm{Y}_{\mathrm{i}}=$ percentage of the ADT at external station $\mathrm{i}$, that are through trips,

I $=$ interstate $(0$ or 1$)$,

$\mathrm{PA}=\operatorname{principal} \operatorname{arterial}(0$ or 1$)$,

$\mathrm{MA}=$ minor arterial $(0$ or 1$)$,

$\mathrm{ADT}_{\mathrm{i}}=$ average daily traffic at external station $\mathrm{i}$,

PTKS $_{i}=\quad$ percentage of trucks excluding vans and pickups at external station $\mathrm{i}$,

$\mathrm{PPS}_{\mathrm{i}}=$ percentage of vans and pickups at external station $\mathrm{i}$,

$\mathrm{POP}=$ population inside the cordon area.

The resulting through trip percentages are presented in Table 3.5 
Table 3.5 -Greenfield Cumulative Through Trips using Modlin's Method

\begin{tabular}{|l|r|r|r|}
\hline Station & Percent EE & AADT & Through \\
\hline SR-9 N & 38.6 & 10007 & 3863 \\
\hline I-70 W ramp & 39.8 & 16860 & 6718 \\
\hline US-40 W & 39.6 & 14446 & 5717 \\
\hline SR-9 S & 39.2 & 8336 & 3268 \\
\hline US-40 E & 39.0 & 9843 & 3838 \\
\hline I-70 E ramp & 38.5 & 5758 & 2219 \\
\hline
\end{tabular}

The next step of Modlin's method requires distribution of trips between stations. The equations used to distribute trips differ by road class. For a destination station located on an Interstate, the following equation is used:

$Y_{j i}=-2.70+0.21 *$ PTTDES $_{j}+67.86 *$ RTECON $_{i j}$

Eq. 3.2

For a destination station on a principal arterial, the equation is:

$$
Y_{i j}=-7.40+0.55 * \text { PTTDES }_{j}+24.68 * \operatorname{RTECON}_{i j}+45.62 * \frac{A D T_{j}}{\sum_{j} A D T_{j}}
$$

For a destination station on a minor arterial, the equation is:

$$
Y_{i j}=-0.63+30.04 * R T E C O N_{i j}+86.68 * \frac{A D T_{j}}{\sum_{j} A D T_{j}}
$$

where:

$\mathrm{Y}_{\mathrm{ij}} \quad=$ percentage distribution of through-trip ends from origin station $\mathrm{i}$ to destination station $\mathrm{j}$,

PTTDES $_{\mathrm{j}}=$ percentage through-trip ends at destination station $\mathrm{j}$,

$\mathrm{RTECON}_{\mathrm{ij}}=$ route continuity between stations $\mathrm{i}$ and $\mathrm{j}: 1=\mathrm{Yes}, 0=\mathrm{No}$, and

$\operatorname{ADT}_{\mathrm{j}}=$ average daily traffic at destination station $\mathrm{j}$.

The matrix describing percentage of trips from each origin to each destination station is shown in Table 3.6. 
Table 3.6 - Greenfield Base Through Trip Percentages using Modlin’s Method

\begin{tabular}{|l|r|r|r|r|r|r|r|}
\hline & \multicolumn{7}{|c|}{ Destination } \\
\hline Origin & SR-9 N & I-70 W & US-40 W & SR-9 S & US-40 E & I-70 E & Total \% \\
\hline SR-9 N & $0 \%$ & $26 \%$ & $24 \%$ & $45 \%$ & $21 \%$ & $18 \%$ & $134 \%$ \\
\hline I-70 W ramp & $46 \%$ & $0 \%$ & $24 \%$ & $45 \%$ & $21 \%$ & $18 \%$ & $153 \%$ \\
\hline US-40 W & $21 \%$ & $26 \%$ & $0 \%$ & $21 \%$ & $46 \%$ & $18 \%$ & $132 \%$ \\
\hline SR-9 S & $46 \%$ & $26 \%$ & $24 \%$ & $0 \%$ & $21 \%$ & $18 \%$ & $135 \%$ \\
\hline US-40 E & $21 \%$ & $26 \%$ & $49 \%$ & $20 \%$ & $0 \%$ & $18 \%$ & $134 \%$ \\
\hline I-70 E ramp & $46 \%$ & $26 \%$ & $24 \%$ & $45 \%$ & $21 \%$ & $0 \%$ & $162 \%$ \\
\hline
\end{tabular}

The percentages calculated across rows above do not add to 100 percent and need to be normalized. The result of this calculation is presented below (Table 3.7).

Table 3.7 - Greenfield Normalized Through Trip Percentages using Modlin's Method

\begin{tabular}{|l|r|r|r|r|r|r|}
\hline & \multicolumn{1}{|l|}{ SR-9 N } & I-70 W & US-40 W & \multicolumn{1}{l|}{ SR-9 S } & US-40 E & \multicolumn{1}{l|}{ I-70 E } \\
\hline SR-9 N & $0 \%$ & $20 \%$ & $18 \%$ & $33 \%$ & $16 \%$ & $13 \%$ \\
\hline I-70 W ramp & $30 \%$ & $0 \%$ & $16 \%$ & $29 \%$ & $14 \%$ & $12 \%$ \\
\hline US-40 W & $16 \%$ & $20 \%$ & $0 \%$ & $16 \%$ & $35 \%$ & $14 \%$ \\
\hline SR-9 S & $34 \%$ & $19 \%$ & $18 \%$ & $0 \%$ & $15 \%$ & $13 \%$ \\
\hline US-40 E & $16 \%$ & $20 \%$ & $37 \%$ & $15 \%$ & $0 \%$ & $13 \%$ \\
\hline I-70 E ramp & $28 \%$ & $16 \%$ & $15 \%$ & $28 \%$ & $13 \%$ & $0 \%$ \\
\hline
\end{tabular}

Next, the number of trips between each pair of external stations is determined by multiplying the percentage of trips from the origin station to the destination station by the total external trips for that origin station (calculated in the first step). The externalinternal trips, which correspond to the diagonal entries in the matrix, are not directly estimated in Modlin's method. However, they are calculated by subtracting the number of external trips from the AADT (Table 3.8). 
Table 3.8 - Greenfield Base Trip Distribution using Modlin's Method

\begin{tabular}{|l|r|r|r|r|r|r|r|}
\hline & SR-9 N & I-70 W & US-40 W & SR-9 S & US-40 E & I-70 E & $\begin{array}{c}\text { Total } \\
\text { external }\end{array}$ \\
\hline SR-9 N & 3072 & 379 & 352 & 643 & 301 & 256 & 1931 \\
\hline I-70 W ramp & 996 & 5071 & 536 & 978 & 458 & 390 & 3359 \\
\hline US-40 W & 456 & 576 & 4365 & 438 & 999 & 390 & 2858 \\
\hline SR-9 S & 551 & 318 & 296 & 2534 & 253 & 216 & 1634 \\
\hline US-40 E & 298 & 376 & 703 & 286 & 3003 & 255 & 1919 \\
\hline I-70 E ramp & 312 & 180 & 168 & 306 & 143 & 1770 & 1109 \\
\hline $\begin{array}{l}\text { Total } \\
\text { external }\end{array}$ & 2613 & 1829 & 2055 & 2651 & 2155 & 1507 & \\
\hline
\end{tabular}

The trips being considered occur over the course of a day. Therefore, the number of trips that travel from the first station to the second one is expected to be the same as the number of trips traveling from the second station back to the first one. As a result, the matrix needs to be symmetric. The matrix is made symmetric by finding the average number of trips traveling between each pair of stations (Table 3.9).

Table 3.9- Greenfield Symmetrical Trip Distribution using Modlin's Method

\begin{tabular}{|l|r|r|r|r|r|r|r|}
\hline & SR-9 N & I-70 W & US-40 W & SR-9 S & US-40 E & I-70 E & $\begin{array}{c}\text { Total } \\
\text { external }\end{array}$ \\
\hline SR-9 N & 3072 & 688 & 404 & 597 & 300 & 284 & 2272 \\
\hline I-70 W ramp & 688 & 5071 & 556 & 648 & 417 & 285 & 2594 \\
\hline US-40 W & 404 & 556 & 4365 & 367 & 851 & 279 & 2457 \\
\hline SR-9 S & 597 & 648 & 367 & 2534 & 270 & 261 & 2143 \\
\hline US-40 E & 300 & 417 & 851 & 270 & 3003 & 199 & 2037 \\
\hline I-70 E ramp & 284 & 285 & 279 & 261 & 199 & 1770 & 1308 \\
\hline $\begin{array}{l}\text { Total } \\
\text { external }\end{array}$ & 2272 & 2594 & 2457 & 2143 & 2037 & 1308 & \\
\hline
\end{tabular}

The final step requires balancing the total number of trips at an external station to the AADT as determined in step 1 of the method. A biproportional balancing method is employed in this case (Meyer, 2001).

Biproportional balancing is an iterative method of balancing trips that ensures that the row and column sums, which in this case correspond to the total number of trips originating at a station or destined to a station, add to the desired value. The process starts 
with the matrix of trips between each pair of origin and destination stations. The first step in the method ensures that the row sums are equal to the desired value (equation 3.5). Next, the entries in the table are adjusted so that the column sums match the desired value (equation 3.6), which in turn results in row sums that do not add to the correct value. Thus, this two step process is repeated until both the row and column totals equal the desired number of trips.

$$
\begin{aligned}
T_{i j}^{k} & =T_{i j}^{k-1}\left(\frac{O_{i}^{\text {des }}}{O_{i}^{k-1}}\right) \\
T_{i j}^{k} & =T_{i j}^{k-1}\left(\frac{D_{j}^{\text {des }}}{D_{j}^{k-1}}\right)
\end{aligned}
$$

where

$\mathrm{k}=$ Iteration number

$T_{i j}^{0} \quad=\quad$ Unadjusted number of trips from origin $\mathrm{i}$ to destination $\mathrm{j}$

$O_{i}^{\text {des }}=$ Desired number of trips at origin $\mathrm{i}$

$D_{j}^{\text {des }}=$ Desired number of trips at destination $\mathrm{j}$

\subsubsection{Results}

The resulting trip table for the Greenfield area that includes the external-external (EE) and external-internal (EI) trips is shown in Table 3.10. In addition, the predicted results are compared to the actual trips in Figure 3.2. In the plot of predicted versus actual trips, the solid line represents the point at which the two counts match. The plot shows that all points, except for one, lie above this line, indicating that through trips between most pairs of external stations are over predicted. 
Table 3.10- Greenfield EE and EI Trip Distribution using Modlin's Method

\begin{tabular}{|l|r|r|r|r|r|r|}
\hline & \multicolumn{1}{|l|}{ SR-9 N } & I-70 W & US-40 W & SR-9 S & US-40 E & \multicolumn{1}{l|}{ I-70 E } \\
\hline SR-9 N & 3072 & 813 & 391 & 335 & 205 & 188 \\
\hline I-70 W ramp & 813 & 5071 & 995 & 673 & 529 & 349 \\
\hline US-40 W & 391 & 995 & 4365 & 312 & 882 & 279 \\
\hline SR-9 S & 335 & 673 & 312 & 2534 & 162 & 152 \\
\hline US-40 E & 205 & 529 & 882 & 162 & 3003 & 141 \\
\hline I-70 E ramp & 188 & 349 & 279 & 152 & 141 & 1770 \\
\hline
\end{tabular}

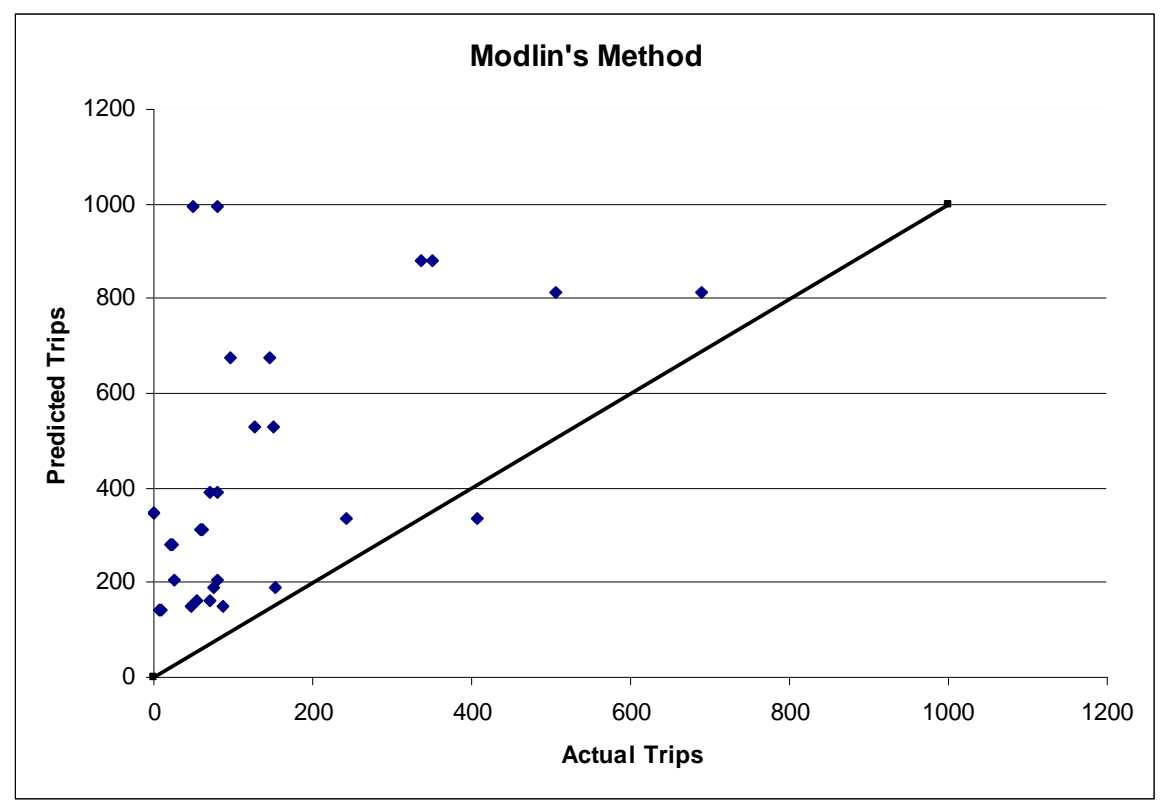

Figure 3.2- Greenfield Predicted versus Actual Trips using Modlin's Method

In addition to calculating the number of trips between each pair of stations, it may be useful to express these through trips as a percentage of trips from the specified origin. The percentage of through trips as well as external-internal trips is shown in Table 3.11. 
Table 3.11- Greenfield EE and EI Trip Percentages using Modlin's Method

\begin{tabular}{|l|r|r|r|r|r|r|}
\hline & SR-9 N & I-70 W & US-40 W & SR-9 S & US-40 E & I-70 E \\
\hline SR-9 N & $61 \%$ & $16 \%$ & $8 \%$ & $7 \%$ & $4 \%$ & $4 \%$ \\
\hline I-70 W ramp & $10 \%$ & $60 \%$ & $12 \%$ & $8 \%$ & $6 \%$ & $4 \%$ \\
\hline US-40 W & $5 \%$ & $14 \%$ & $60 \%$ & $4 \%$ & $12 \%$ & $4 \%$ \\
\hline SR-9 S & $8 \%$ & $16 \%$ & $7 \%$ & $61 \%$ & $4 \%$ & $4 \%$ \\
\hline US-40 E & $4 \%$ & $11 \%$ & $18 \%$ & $3 \%$ & $61 \%$ & $3 \%$ \\
\hline I-70 E ramp & $7 \%$ & $12 \%$ & $10 \%$ & $5 \%$ & $5 \%$ & $61 \%$ \\
\hline
\end{tabular}

The next step in evaluating Modlin's method is calculating the error. In most analyses, the error would be calculated as $\frac{\text { predicted trips - actual trips }}{\text { actual trips }}$ for each pair of stations and then averaged. However, in this case, the volumes vary greatly between different pair of stations and this calculation may not be indicative of the suitability of the model. For example, if the number of trips between two external stations is predicted as 10 and in reality the number of trips is 2 , one would get 500 percent error, while a discrepancy of 100 vehicles between 1000 and 900 trips would only correspond to a 10 percent error. Thus, one way to estimate the error is by calculating the absolute difference between the predicted and the actual trips and averaging it for external-external and external-internal trips. In this case the observed trips are subtracted from the predicted trips for each pair of stations and then averaged for external-external stations and external-internal stations. The average errors in the number of external-external and external-internal trips are calculated to be 290 and -1531 respectively (Table 3.12).

Table 3.12- Greenfield Differences between Actual and Estimated Trips using Modlin's Method

\begin{tabular}{|l|r|r|r|r|r|r|}
\hline & \multicolumn{1}{|l|}{ SR-9 N } & \multicolumn{1}{l|}{ I-70 W } & US-40 W & \multicolumn{1}{l|}{ SR-9 S } & US-40 E & I-70 E \\
\hline SR-9 N & -932 & 307 & 320 & 93 & 180 & 113 \\
\hline I-70 W ramp & 124 & -2183 & 915 & 576 & 401 & 349 \\
\hline US-40 W & 312 & 946 & -2607 & 251 & 531 & 255 \\
\hline SR-9 S & -71 & 527 & 254 & -938 & 109 & 105 \\
\hline US-40 E & 125 & 378 & 545 & 91 & -1765 & 132 \\
\hline I-70 E ramp & 35 & 349 & 258 & 66 & 135 & -758 \\
\hline $\begin{array}{l}\text { Average EE } \\
\text { error }\end{array}$ & 290 & & & & & \\
\hline $\begin{array}{l}\text { Average IE } \\
\text { error }\end{array}$ & -1531 & & & & & \\
\hline
\end{tabular}


Another way of calculating the error is by finding the difference between the percentage of predicted trips and actual trips for each pair of stations. An average percent error can then be evaluated separately for external-external and external-internal trips. The percent distribution of trips between origins and destinations is presented in Table 3.13. Computing the average percent error for external-external trips and external-internal trips yields 5.3 percent and -26 percent, respectively.

Table 3.13- Greenfield Percent Error between Actual and Estimated Trips using Modlin's Method

\begin{tabular}{|l|r|r|r|r|r|r|}
\hline & SR-9 N & I-70 W & US-40 W & \multicolumn{1}{l|}{ SR-9 S } & US-40 E & I-70 E \\
\hline SR-9 N & $-19.93 \%$ & $5.96 \%$ & $6.37 \%$ & $1.78 \%$ & $3.59 \%$ & $2.23 \%$ \\
\hline I-70 W ramp & $1.29 \%$ & $-27.79 \%$ & $10.83 \%$ & $6.81 \%$ & $4.72 \%$ & $4.14 \%$ \\
\hline US-40 W & $4.36 \%$ & $13.12 \%$ & $-32.09 \%$ & $3.51 \%$ & $7.55 \%$ & $3.55 \%$ \\
\hline SR-9 S & $-1.67 \%$ & $12.67 \%$ & $6.09 \%$ & $-22.23 \%$ & $2.62 \%$ & $2.51 \%$ \\
\hline US-40 E & $2.69 \%$ & $7.95 \%$ & $11.69 \%$ & $1.99 \%$ & $-27.03 \%$ & $2.70 \%$ \\
\hline I-70 E ramp & $1.05 \%$ & $12.13 \%$ & $8.95 \%$ & $2.19 \%$ & $4.69 \%$ & $-29.01 \%$ \\
\hline $\begin{array}{l}\text { Average EE } \\
\% \text { error }\end{array}$ & $5.27 \%$ & & & & & \\
\hline $\begin{array}{l}\text { Average IE } \\
\% \text { error }\end{array}$ & $-26.35 \%$ & & & & & \\
\hline
\end{tabular}

A third way to determine the effectiveness of the model is by calculating the root mean square error (RMSE), which corresponds to the average distance between the estimated percentage of through trips and the actual percentage of trips. The definition of RMSE is included in equation 3.7.

$$
R M S E=\sqrt{E\left[(Y i-Y)^{2}\right]}
$$

Modlin's method yields an RMSE of 12.4 percent. This value may not be very meaningful on its own. However it provides a measure of the model's effectiveness when compared to other methods. 


\subsubsection{Sensitivity Analysis}

Sensitivity analysis may prove useful because the route continuity factor is not clearly defined in the report, and the percentage of vans and pickup vehicles is not available for the Greenfield area.

\subsubsection{Percentage of vans and pickup trucks}

The Greenfield data that was available did not provide the percentage of pickup trucks and vans (PPS) and thus the PPS for all the roads in the study area was assumed to equal to the PPS obtained from the WIM detectors installed on an interstate. Furthermore, the PPS varied seasonally between $24 \%$ and $40 \%$, with an average value of $31 \%$, which was used in estimating the trips in section 3.2.2. While the variation in PPS on different routes is unrelated to the seasonal variation, it is expected to be less than the seasonal variation. Thus, considering the seasonal variation will provide the upper and lower bounds for this factor.

In the case of vans and pickup trucks comprising $24 \%$ of the traffic flow, the percentage of through trips increased for all the stations. The new external trips percentages are shown in Table 3.12.

Table 3.14- Greenfield Through Trip Percentages with PPSi= 24\% using Modlin's Method

\begin{tabular}{|l|r|r|r|}
\hline \multicolumn{1}{|c|}{ Station } & Percent EE & AADT & external trips \\
\hline SR-9 N & 41.5 & 10007 & 4151 \\
\hline I-70 W ramp & 42.7 & 16860 & 7203 \\
\hline US-40 W & 42.5 & 14446 & 6133 \\
\hline SR-9 S & 42.1 & 8336 & 3508 \\
\hline US-40 E & 41.9 & 9843 & 4121 \\
\hline I-70 E ramp & 41.4 & 5758 & 2384 \\
\hline
\end{tabular}


The resulting trip matrix, calculated as described in section 3.2.2, is presented in Table 3.13. The RMSE increased from 12.4 percent to 13.7 percent, while the average percent error rose from 5.3 percent to 6.1 percent for through trips and from -26 percent to -31 percent for EI trips.

Table 3.15- Greenfield Through Trip Distribution with PPSi=24\% using Modlin's Method

\begin{tabular}{|l|r|r|r|r|r|r|}
\hline & SR-9 N & I-70 W & US-40 W & SR-9 S & US-40 E & \multicolumn{1}{l|}{ I-70 E } \\
\hline SR-9 N & 2681 & 747 & 437 & 552 & 307 & 279 \\
\hline I-70 W ramp & 747 & 5539 & 670 & 678 & 477 & 320 \\
\hline US-40 W & 437 & 670 & 4519 & 383 & 911 & 304 \\
\hline SR-9 S & 552 & 678 & 383 & 2044 & 266 & 246 \\
\hline US-40 E & 307 & 477 & 911 & 266 & 2755 & 205 \\
\hline I-70 E ramp & 279 & 320 & 304 & 246 & 205 & 1525 \\
\hline
\end{tabular}

For the case of 40 percent of the traffic flow being vans and pickup trucks, the percentages of through trips (as calculated from the first step of Modlin's method) are described in Table 3.14 and the overall trip distribution is in Table 3.15. In this case, the errors improved to from 5.3 percent to 4.4 percent for external-external trips and from 26 percent to -22 percent for EI trips. The RMSE error also dropped to 10.3 percent, which is an improvement from 12.4 percent.

Table 3.16- Greenfield Through Trip Percentages with PPSi $=40 \%$ using Modlin's Method

\begin{tabular}{|l|r|r|r|}
\hline Station & \multicolumn{1}{|l|}{$\begin{array}{l}\text { Percent } \\
\text { external }\end{array}$} & \multicolumn{1}{|l|}{ AADT } & external trips \\
\hline SR-9 N & 33.8 & 10007 & 3383 \\
\hline I-70 W ramp & 35.0 & 16860 & 5908 \\
\hline US-40 W & 34.8 & 14446 & 5023 \\
\hline SR-9 S & 34.4 & 8336 & 2868 \\
\hline US-40 E & 34.2 & 9843 & 3365 \\
\hline I-70 E ramp & 33.7 & 5758 & 1942 \\
\hline
\end{tabular}


Table 3.17- Greenfield Through Trip Distribution with PPSi=40\% using Modlin's Method

\begin{tabular}{|l|r|r|r|r|r|r|}
\hline \multicolumn{7}{|c|}{ Destination } \\
\hline SR-9 N & SR-9 N & I-70 W & US-40 W & SR-9 S & US-40 E & I-70 E \\
\hline I-70 W ramp & 3069 & 626 & 345 & 491 & 241 & 230 \\
\hline US-40 W & 626 & 6090 & 526 & 573 & 371 & 243 \\
\hline SR-9 S & 345 & 526 & 5018 & 303 & 797 & 235 \\
\hline US-40 E & 491 & 573 & 303 & 2385 & 210 & 206 \\
\hline I-70 E ramp & 241 & 371 & 797 & 210 & 3144 & 158 \\
\hline
\end{tabular}

The sensitivity analysis indicates that, when the percentage of pickups and vans increases from 31 percent to 40 percent, the average errors in through trips drops from 5.3 percent to 4.4 percent, while the error in the external-internal trips decreases from -26 percent to -22 percent. This is a large change and thus, when applying Modlin's method, accurate values for PPS need to be obtained. However, this information is usually not readily available, requiring guesswork that may lead to incorrect conclusions. Therefore, it may be preferable to use a method that does not rely on this parameter.

\subsubsection{Route Continuity Factor}

As mentioned before, four external stations near Greenfield are located on the I70 ramps. The NCHRP Report 365 (Martin and McGuckin, 1998) does not consider such cases and, therefore, it is unclear whether the route between the stations on SR-9 and the ramps leading from SR-9 onto I-70 should be classified as continuous. In the section 3.2.2 analysis, this route was not considered to be continuous, possibly resulting in underestimation of trips between external stations on SR-9 and I-70. Thus, a case where the route is considered continuous is examined. The through trips resulting from this analysis are presented in Table 3.16. 
Table 3.18 - Greenfield Through Trip Distribution with Different Route Continuity Factor

\begin{tabular}{|l|r|r|r|r|r|r|}
\hline & SR-9 N & I-70 W & US-40 W & SR-9 S & US-40 E & I-70 E \\
\hline SR-9 N & 2879 & 781 & 359 & 396 & 249 & 340 \\
\hline I-70 W ramp & 781 & 5621 & 609 & 705 & 436 & 278 \\
\hline US-40 W & 360 & 610 & 4776 & 330 & 879 & 268 \\
\hline SR-9 S & 396 & 705 & 330 & 2222 & 219 & 296 \\
\hline US-40 E & 249 & 436 & 879 & 219 & 2956 & 183 \\
\hline I-70 E ramp & 340 & 278 & 268 & 296 & 183 & 1515 \\
\hline
\end{tabular}

The change in the route continuity factors resulted in average errors increasing from 5.3 percent and -26 percent to 5.6 percent for EE and - 28 percent for IE trips. The RMSE also increased from 12.4 percent to 13.0 percent, indicating worse performance as compared to the original model. The sensitivity analysis suggests that considering the route between SR-9 stations and ramps located on SR-9 as continuous does not considerably change the trip distribution. As mentioned before, route continuity factor also does not affect the overall percentage of through trips, because it is not a variable used in the first step of Modlin's method.

\subsection{Anderson's Method}

Anderson's method for predicting external trips is similar to Modlin's method. Anderson uses a linear regression equation to predict the percentage of through trips between each pair of external stations. However, unlike Modlin, Anderson estimates both the percentages of external-external and external-internal trips in one step.

\subsubsection{Data}

The data requirements for Anderson's analysis are similar to those of the Modlin method and include AADT and route continuity factors. In addition, Anderson uses an indicator variable to incorporate the effect of a nearby major center. The external-internal 
factor is also included in this model because, unlike Modlin's method, Anderson's equation predicts the external-internal trips as well as through trips.

\subsubsection{Method}

As mentioned previously, Anderson's method uses a linear regression equation to estimate both through and external-internal trips in one step (equation 3.8)

$$
Y_{i j}=11.368-0.0004968 * A D T_{j}+11.57 * N M C_{j}+9.187 * R T E C O N_{i j}+44.857 * I E F
$$

Eq. 3.8

where

$$
\begin{array}{ll}
\mathrm{ADT}_{\mathrm{j}} & =\text { average daily traffic at external station } \mathrm{j}, \\
\mathrm{NMC}_{\mathrm{j}} & =\text { nearby major city at destination } \mathrm{j}, \\
\mathrm{RTECON}_{\mathrm{ij}} & =\text { route continuity between stations I and } \mathrm{j}, \\
\mathrm{IEF} & =\text { internal-external factor }(1 \text { if } \mathrm{i}=\mathrm{j})
\end{array}
$$

The trip percentages resulting from the application of equation 3.8 to each pair of external stations are presented in Table 3.17. In the next step, these percentages are adjusted to add up to $100 \%$ for each origin. Then, the number of trips between each pair of stations is calculated by multiplying the percentage of trips by half of the AADT (Because the AADT used in the analysis is two-way AADT, all trips from an origin to all destinations need to add to half of the AADT.) After the trips are calculated, and made symmetrical, they are balanced to AADT using the biproportional method described in section 3.2.2. 
Table 3.19- Greenfield Base Trip Percentages using Anderson's Method

\begin{tabular}{|l|r|r|r|r|r|r|}
\hline & SR-9 N & I-70 W & US-40 W & SR-9 S & \multicolumn{1}{l|}{ US-40 E } & \multicolumn{1}{l|}{ I-70 E } \\
\hline SR-9 N & $51 \%$ & $15 \%$ & $16 \%$ & $16 \%$ & $6 \%$ & $9 \%$ \\
\hline I-70 W ramp & $16 \%$ & $59 \%$ & $16 \%$ & $16 \%$ & $6 \%$ & $9 \%$ \\
\hline US-40 W & $6 \%$ & $15 \%$ & $61 \%$ & $7 \%$ & $16 \%$ & $9 \%$ \\
\hline SR-9 S & $16 \%$ & $15 \%$ & $16 \%$ & $52 \%$ & $6 \%$ & $9 \%$ \\
\hline US-40 E & $6 \%$ & $15 \%$ & $25 \%$ & $7 \%$ & $51 \%$ & $9 \%$ \\
\hline I-70 E ramp & $16 \%$ & $15 \%$ & $16 \%$ & $16 \%$ & $6 \%$ & $53 \%$ \\
\hline
\end{tabular}

\subsubsection{Results}

The resulting origin destination matrix using Anderson's method is presented in Table 3.18, while the percent distribution of trips between origins and destinations is shown in Table 3.19. The corresponding scatterplot of predicted versus actual trips is presented in Figure 3.3. Similar to Modlin's method, it is evident that the through trips are largely overpredicted.

Table 3.20- Greenfield EE and EI trip Distribution using Anderson's Method

\begin{tabular}{|l|r|r|r|r|r|r|}
\hline & \multicolumn{1}{|l|}{ SR-9 N } & I-70 W & US-40 W & SR-9 S & US-40 E & I-70 E \\
\hline SR-9 N & 2290 & 914 & 542 & 611 & 297 & 349 \\
\hline I-70 W ramp & 914 & 4591 & 1042 & 826 & 598 & 459 \\
\hline US-40 W & 542 & 1042 & 3684 & 476 & 1063 & 416 \\
\hline SR-9 S & 611 & 826 & 476 & 1679 & 270 & 306 \\
\hline US-40 E & 297 & 598 & 1063 & 270 & 2439 & 255 \\
\hline I-70 E ramp & 349 & 459 & 416 & 306 & 255 & 1094 \\
\hline
\end{tabular}

Table 3.21- Greenfield EE and EI Trip Percentages using Anderson's Method

\begin{tabular}{|l|r|r|r|r|r|r|}
\hline & \multicolumn{1}{|l|}{ SR-9 N } & I-70 W & US-40 W & SR-9 S & \multicolumn{1}{l|}{ US-40 E } & I-70 E \\
\hline SR-9 N & $46 \%$ & $18 \%$ & $11 \%$ & $12 \%$ & $6 \%$ & $7 \%$ \\
\hline I-70 W ramp & $11 \%$ & $54 \%$ & $12 \%$ & $10 \%$ & $7 \%$ & $5 \%$ \\
\hline US-40 W & $8 \%$ & $14 \%$ & $51 \%$ & $7 \%$ & $15 \%$ & $6 \%$ \\
\hline SR-9 S & $15 \%$ & $20 \%$ & $11 \%$ & $40 \%$ & $6 \%$ & $7 \%$ \\
\hline US-40 E & $6 \%$ & $12 \%$ & $22 \%$ & $5 \%$ & $50 \%$ & $5 \%$ \\
\hline I-70 E ramp & $12 \%$ & $16 \%$ & $14 \%$ & $11 \%$ & $9 \%$ & $38 \%$ \\
\hline
\end{tabular}




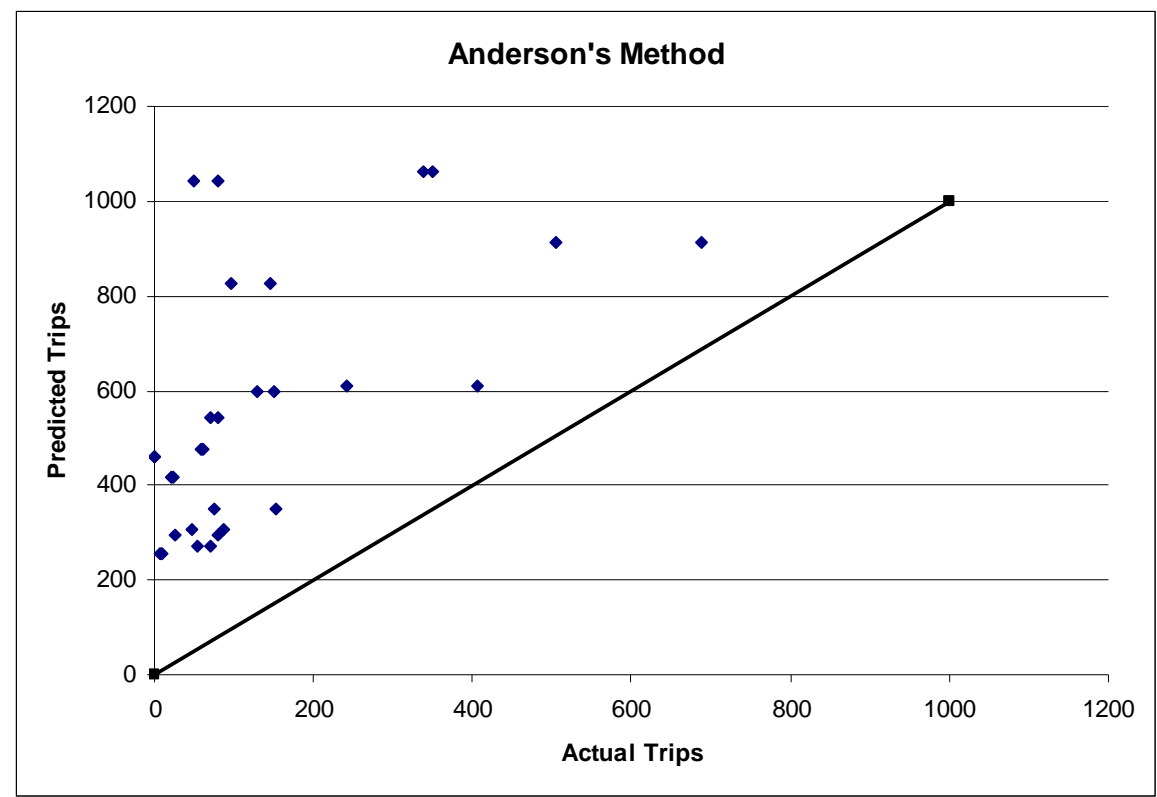

Figure 3.3- Greenfield Trips Predicted by Anderson's Method versus Actual Trips

The error in the number of trips in this case is 425 for through trips and -2203 for trips with an origin or a destination within the cordon line (for errors between each pair of stations see Table 3.20). The average percent error for external-external trips is 8 percent and external-internal trips -41 percent (Table 3.21). The RMSE for Anderson's method is 18.7 percent, which is much higher than that for Modlin's method. This indicates that Anderson's method performs worse than Modlin's method for the city of Greenfield.

Table 3.22- Greenfield Differences between Estimated and Actual Trips using Anderson's Method

\begin{tabular}{|l|r|r|r|r|r|r|}
\hline & SR-9 N & I-70 W & US-40 W & \multicolumn{1}{l|}{ SR-9 S } & \multicolumn{1}{l|}{ US-40 E } & I-70 E \\
\hline SR-9 N & -1714 & 408 & 471 & 369 & 272 & 274 \\
\hline I-70 W ramp & 225 & -2663 & 962 & 729 & 470 & 459 \\
\hline US-40 W & 463 & 993 & -3288 & 415 & 712 & 392 \\
\hline SR-9 S & 205 & 680 & 418 & -1793 & 217 & 259 \\
\hline US-40 E & 217 & 447 & 726 & 199 & -2329 & 246 \\
\hline I-70 E ramp & 196 & 459 & 395 & 220 & 249 & -1434 \\
\hline $\begin{array}{l}\text { Average EE } \\
\text { error }\end{array}$ & 424 & & & & & \\
\hline $\begin{array}{l}\text { Average IE } \\
\text { error }\end{array}$ & -2203 & & & & & \\
\hline
\end{tabular}


Table 3.23- Greenfield Differences between the Percentages of Estimated and Actual Trips

\begin{tabular}{|l|r|r|r|r|r|r|}
\hline & \multicolumn{1}{|c|}{ SR-9 N } & I-70 W & US-40 W & \multicolumn{1}{|c|}{ SR-9 S } & US-40 E & I-70 E \\
\hline SR-9 N & $-35.56 \%$ & $8.00 \%$ & $9.39 \%$ & $7.30 \%$ & $5.42 \%$ & $5.44 \%$ \\
\hline I-70 W ramp & $2.49 \%$ & $-33.49 \%$ & $11.39 \%$ & $8.62 \%$ & $5.54 \%$ & $5.45 \%$ \\
\hline US-40 W & $6.46 \%$ & $13.77 \%$ & $-41.51 \%$ & $5.78 \%$ & $10.06 \%$ & $5.45 \%$ \\
\hline SR-9 S & $4.96 \%$ & $16.33 \%$ & $10.02 \%$ & $-42.73 \%$ & $5.22 \%$ & $6.21 \%$ \\
\hline US-40 E & $4.55 \%$ & $9.35 \%$ & $15.38 \%$ & $4.18 \%$ & $-38.48 \%$ & $5.01 \%$ \\
\hline I-70 E ramp & $6.63 \%$ & $15.95 \%$ & $13.71 \%$ & $7.53 \%$ & $8.64 \%$ & $-52.46 \%$ \\
\hline $\begin{array}{l}\text { Average EE } \\
\text { error }\end{array}$ & $8.14 \%$ & & & & & \\
\hline $\begin{array}{l}\text { Average IE } \\
\text { error }\end{array}$ & $-40.71 \%$ & & & & & \\
\hline
\end{tabular}

\subsubsection{Sensitivity Analysis}

\subsubsection{Route Continuity Factor}

Similar to Modlin's method, Anderson's model employs a route continuity factor to predict the through trip movements. Due to the absence of a clear definition of this factor, sensitivity analysis needed to be performed. Two cases were considered as described in section 3.2.4, with the first case results discussed in the previous section. For the second case, in which the route between SR-9 stations and ramps leading from SR-9 onto I-70 was considered continuous, the results are presented in Table 3.22.

Table 3.24- Greenfield Trip Distribution with a Different Route Continuity Factor

\begin{tabular}{|l|r|r|r|r|r|r|}
\hline \multicolumn{9}{|c|}{ Destination } \\
\hline & SR-9 N & I-70 W & US-40 W & SR-9 S & US-40 E & I-70 E \\
\hline SR-9 N & 2105 & 1064 & 516 & 562 & 286 & 471 \\
\hline I-70 W ramp & 1064 & 4389 & 1028 & 943 & 588 & 420 \\
\hline US-40 W & 516 & 1028 & 3751 & 457 & 1079 & 393 \\
\hline SR-9 S & 562 & 943 & 457 & 1543 & 264 & 399 \\
\hline US-40 E & 286 & 587 & 1079 & 264 & 2465 & 240 \\
\hline I-70 E ramp & 471 & 420 & 393 & 399 & 240 & 956 \\
\hline
\end{tabular}


The average error in the external-external trips changed from $8 \%$ to $8.6 \%$, while for internal-external trips rose from 41 percent to 43 percent. The RMSE for the modified route continuity factors increased from 18.7 to 19.7 percent. Due to rather small changes in the trip distribution, the route continuity between SR-9 and ramps leading onto I-70 was concluded not to be a significant factor in Anderson's analysis.

\subsection{Subarea Analysis}

Unlike Modlin's and Anderson's methods, which rely on linear equations, subarea analysis method is a macro simulation performed in TransCAD. This analysis extracts the origin-destination trip table for a subarea from the statewide origin-destination table.

\subsubsection{Data}

The input data required for the subarea analysis includes the Indiana Statewide Travel Demand Model (ISTDM), which incorporates all the node and link data for the network and origin-destination trip table. The statewide total daily origin-destination matrix is obtained by running the four-step procedure for the state network, including trip generation, trip distribution, mode choice and trip assignment.

\subsection{2 $\underline{\text { Method }}$}

Before the subarea procedure is performed, the master network and the total daily origin-destination matrix are opened. The analysis starts with the delineation of a subarea by specifying a cordon line. Then, the subarea option is selected from the planning utilities menu and the option corresponding to subarea selection by polygon is chosen. TransCAD then identifies the centroids within the subarea as well as the external stations

(those located outside the subarea on the routes that cross the cordon line). In addition, 
constants $\alpha$ and $\beta$ for the BPR delay function are set equal to the parameter values used in the network. Lastly, the global parameter set for the analysis is specified as 20 iterations, 0.01 convergence level, alpha of 0.15 and beta of 4.0. The global alpha and beta will actually be ignored in the analysis because, in the previous step, they were specified for each road segment in the network.

After getting a subarea origin destination matrix from TransCAD, it is made symmetrical and balanced to the actual AADT observed at the external stations in the area as described in section 3.2.2.

\subsubsection{Results}

The resulting number of trips between each pair of stations and percentage of trip distributions are presented in Tables 3.23 and 3.24, respectively. Figure 3.4 displays the scatterplot of the predicted versus the actual trips. It is clear that the trips are more evenly distributed about the line than in Modlin's and Anderson's methods, indicating better model performance. The average error in the number of trips between pairs of stations is 134 trips for the external-external case and -748 trips for external-internal case. The percent errors are 1.96 percent and -10.9 percent for the through trips and the externalinternal trips, respectively. The RMSE that was obtained from the subarea analysis is 7.75 percent.

Table 3.25- Greenfield EE and EI Trips using Subarea Analysis

\begin{tabular}{|l|r|r|r|r|r|r|}
\hline & \multicolumn{1}{|l|}{ SR-9 N } & I-70 W & US-40 W & \multicolumn{1}{l|}{ SR-9 S } & US-40 E & I-70 E \\
\hline SR-9 N & 3051 & 1552 & 6 & 386 & 8 & 0 \\
\hline I-70 W ramp & 1512 & 5947 & 0 & 74 & 896 & 0 \\
\hline US-40 W & 4 & 0 & 6204 & 218 & 713 & 83 \\
\hline SR-9 S & 424 & 212 & 185 & 3276 & 4 & 67 \\
\hline US-40 E & 5 & 719 & 703 & 194 & 3301 & 0 \\
\hline I-70 E ramp & 6 & 0 & 125 & 20 & 0 & 2729 \\
\hline
\end{tabular}


Table 3.26- Greenfield Trip Percentages using Subarea Analysis

\begin{tabular}{|l|r|r|r|r|r|r|}
\hline & SR-9 N & I-70 W & US-40 W & SR-9 S & US-40 E & \multicolumn{1}{l|}{ I-70 E } \\
\hline SR-9 N & $61.0 \%$ & $31.0 \%$ & $0.1 \%$ & $7.7 \%$ & $0.2 \%$ & $0.0 \%$ \\
\hline I-70 W ramp & $17.9 \%$ & $70.5 \%$ & $0.0 \%$ & $0.9 \%$ & $10.6 \%$ & $0.0 \%$ \\
\hline US-40 W & $0.1 \%$ & $0.0 \%$ & $85.9 \%$ & $3.0 \%$ & $9.9 \%$ & $1.2 \%$ \\
\hline SR-9 S & $10.2 \%$ & $5.1 \%$ & $4.4 \%$ & $78.6 \%$ & $0.1 \%$ & $1.6 \%$ \\
\hline US-40 E & $0.1 \%$ & $14.6 \%$ & $14.3 \%$ & $3.9 \%$ & $67.1 \%$ & $0.0 \%$ \\
\hline I-70 E ramp & $0.2 \%$ & $0.0 \%$ & $4.3 \%$ & $0.7 \%$ & $0.0 \%$ & $94.8 \%$ \\
\hline
\end{tabular}

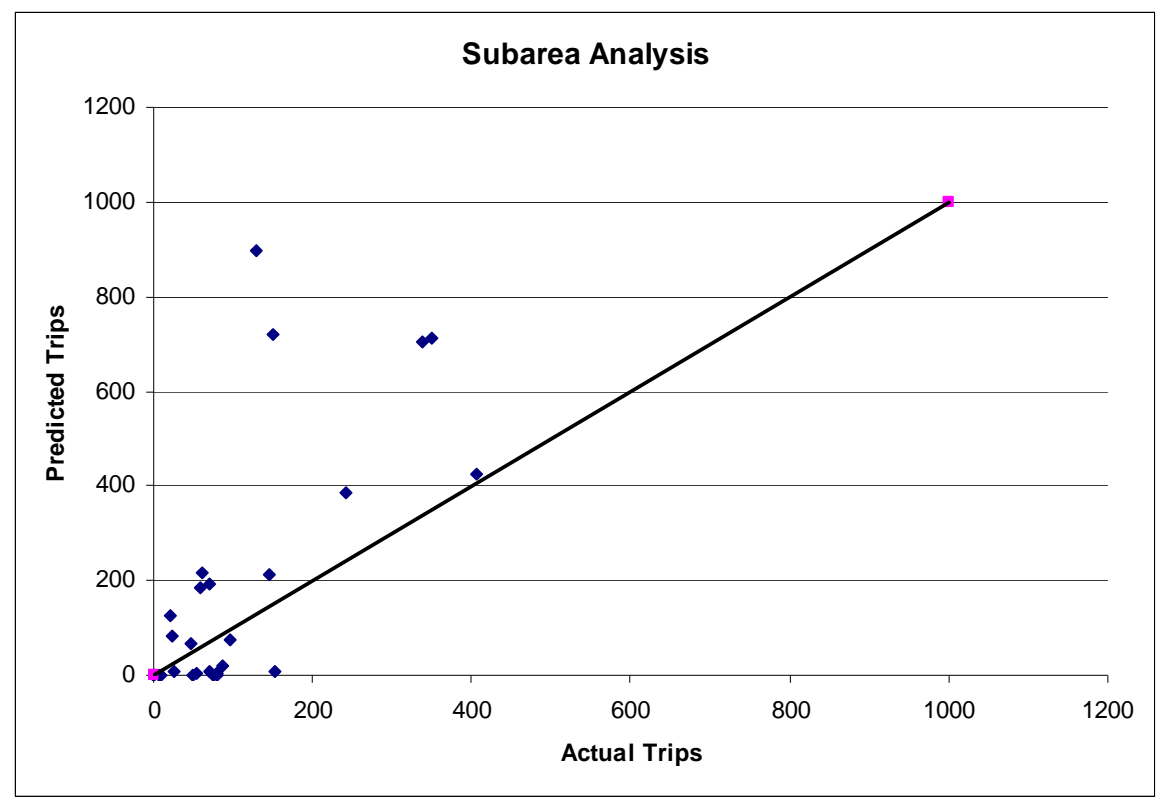

Figure 3.4- Greenfield Predicted versus Actual Trips using Subarea Analysis

\section{$3.5 \underline{\text { Summary }}$}

Estimation of an origin-destination table using Modlin's, Anderson's, and subarea analysis methods yields very different results. In the analysis above, it has been shown that Anderson's model produced the worst results, followed by Modlin's model and then subarea analysis. The discrepancies between the actual trips and the estimated trips are summarized in Table 3.25. Subarea analysis resulted in the best performance, because the model is able to account for the network interactions and the network geometry, thus creating more realistic traffic flows. 
Table 3.27- Greenfield Errors Arising from using Different Models

\begin{tabular}{|l|r|r|r|r|r|}
\hline & \multicolumn{1}{|c|}{ EE Trips } & \multicolumn{1}{l|}{ IE Trips } & EE Trip \% & \multicolumn{1}{l|}{ IE Trip \% } & \multicolumn{1}{l|}{ RMSE } \\
\hline Modlin's Method & 290 & -1531 & $5.27 \%$ & $-26.35 \%$ & 12.4 \\
\hline Anderson's Method & 425 & -2203 & $8.14 \%$ & $-40.71 \%$ & 18.7 \\
\hline Subarea Analysis & 134 & -748 & $1.96 \%$ & $-10.9 \%$ & 7.75 \\
\hline
\end{tabular}

In addition to producing subpar results, Modlin's and Anderson's methods suffer from a number of issues. The first problem is the lack of clarity in the definition of variables such as "route continuity" and "nearby major center", which are not explained sufficiently by either author. Furthermore, Modlin's and Anderson's publications do not explain the effect of the factors included in the models, possibly resulting in counterintuitive results. For example, Modlin's model indicates that an increase in the relative $\mathrm{AADT}$ at the destination station increases the percentage of trips destined to that station. Meanwhile, Anderson arrives at the conclusion that a higher AADT at the destination station reduces the number of trips destined to that station. This discrepancy may be disconcerting for the planner because neither author justifies his conclusions.

Additionally, when the through trip percentages are determined, they do not add to 100 percent and need to be balanced, possibly resulting in a skewed trip distribution. Thus, it appears that the destination choice is not modeled well using linear regression and a choice based model is more appropriate. 


\section{CHAPTER 4. LOGIT MODEL}

Modlin's and Anderson's methods for estimating through trips suffer from two deficiencies. First, the choice of linear regression as a model for estimating the through trip percentage is not justified by either author. Regression appears to have been chosen because of its simplicity, possibly without recognizing all the assumptions underlying it. This results in through trip percentages that do not add up to 100 percent for each origin, making balancing necessary. Balancing preserves the relative proportion of vehicles traveling from a certain origin to all the destinations, but it does not preserve the actual percentages. Instead of using a linear regression model and balancing the trips afterwards, it appears to be more appropriate to use a multinomial logit model that predicts proportions of trips traveling to each destination. In this model, the driver of each vehicle entering the area is assumed to have a choice of exiting at any of the destinations. The likelihood of choosing any destination is reflected in a utility function that contains the attributes of that exit point, such as AADT, percent trucks, and functional class. All the individual decisions would then be aggregated, and the probability of choosing a particular destination, given an origin, would be the same as the total percentage of vehicles traveling from the specified origin to that destination. Thus, selection of a destination from all the possible ones would be appropriately described by a choice based model, which would also ensure that the through trip percentages add up to 100 percent.

The second shortcoming of Modlin's and Anderson's methods is the definition of

the route continuity factor. Both Modlin and Anderson left this factor to be guessed by the planner, with no guidelines on its selection. While a very precise definition may not 
be appropriate, because it would not capture any unusual local traffic patterns, there needs to be a set of rules to help select the correct value for this factor.

The subarea analysis feature in the TransCAD software that runs the Indiana Statewide Travel Demand Model (ISTDM) is a good way to estimate through trips for urban areas, because the area of interest is evaluated in the context of the statewide network. TransCAD also has a selected link feature that permits analysts to estimate the origin-destination patterns of trips that are using a specified link. However, because of INDOT's decentralized planning department structure, these methods would require that employees at every district office be familiar with TransCAD, which is not always the case. Thus a simpler tool, such as a multinomial logit model, would be more suitable.

\subsection{Statistical Formulation}

The multinomial logit model is used to represent a choice-based decision. It has the following form (Washington et al., 2003):

$$
P(a)=\frac{e^{U_{a}}}{e^{U_{a}}+e^{U_{b}}+\ldots}
$$

where

$P(a)=$ probability of choosing option a

$\mathrm{U}_{\mathrm{a}}=$ utility function associated with option a

\section{Data}

In order to select parameters relevant in the prediction of through trips and estimate the corresponding coefficients, the first step was to obtain through trip data and geographic data for cities in Indiana. The only through trip tables that available were those estimated from vehicle license plate surveys for the cities of Greenfield and LaPorte. These trips, however, could not be used to calibrate the model, because they were necessary to validate the model and compare it to the existing ones. Thus, simulated 
data was chosen to approximate the actual through trip counts. This data was to be obtained for a number of cities in Indiana by running the subarea analysis in TransCAD, as explained in section 3.4. As shown in section 3.4, the subarea analysis method yields a reasonable through trip table for the Greenfield area and can be used for model calibration in the absence of actual count data.

Fifteen cities in Indiana were chosen to estimate the model. Only cities with population between 5,000 and 30,000 residents were considered, because cities with populations below 5,000 people do not usually have to face decisions concerning a bypass or traffic rerouting, and cities with population above 30,000 are more likely to justify the expense of vehicle license plate origin-destination survey. In addition to the population constraint, the city used for calibration could not have a bypass. The "no bypass" requirement acknowledges altered traffic patterns resulting from a bypass and a city with existing bypass will probably not be considering another traffic diversion strategy. Moreover, only cities that have all the external stations located on major routes are considered, because if the average annual daily traffic is not available at one of the external stations, the model cannot be estimated. An exception to this rule is possible when a station, located on a road with no AADT information, has less than 3 percent of traffic destined to it from any origin station. In this case, the station can be ignored. Finally, only cities located sufficiently far from large urban centers were used, because the metropolitan areas are difficult to delineate and they may affect travel patterns. For example, most people residing in a community close to a large city such as Chicago will work in Chicago, resulting in a many trips being internal-external. The chosen cities are listed in Table 4.1 and shown on the map in Figure 3.5. Individual maps of the cities, including the locations of external stations, are available in Appendix A. 
Table 4.1- Indiana Cities Used in the Estimation of the Logit Model

\begin{tabular}{|l|r|}
\hline City & Population \\
\hline Greensburg & 10,260 \\
\hline Washington & 11,380 \\
\hline Martinsville & 11,698 \\
\hline Jasper & 12,100 \\
\hline Peru & 12,994 \\
\hline Bedford & 13,768 \\
\hline Elwood & 9,737 \\
\hline Bluffton & 9,536 \\
\hline Tell City & 7,845 \\
\hline Brazil & 8,188 \\
\hline Kendallville & 9,616 \\
\hline Shelbyville & 17,951 \\
\hline Vincennes & 18,701 \\
\hline Seymour & 18,101 \\
\hline New Castle & 17,780 \\
\hline Franklin & 19,463 \\
\hline
\end{tabular}




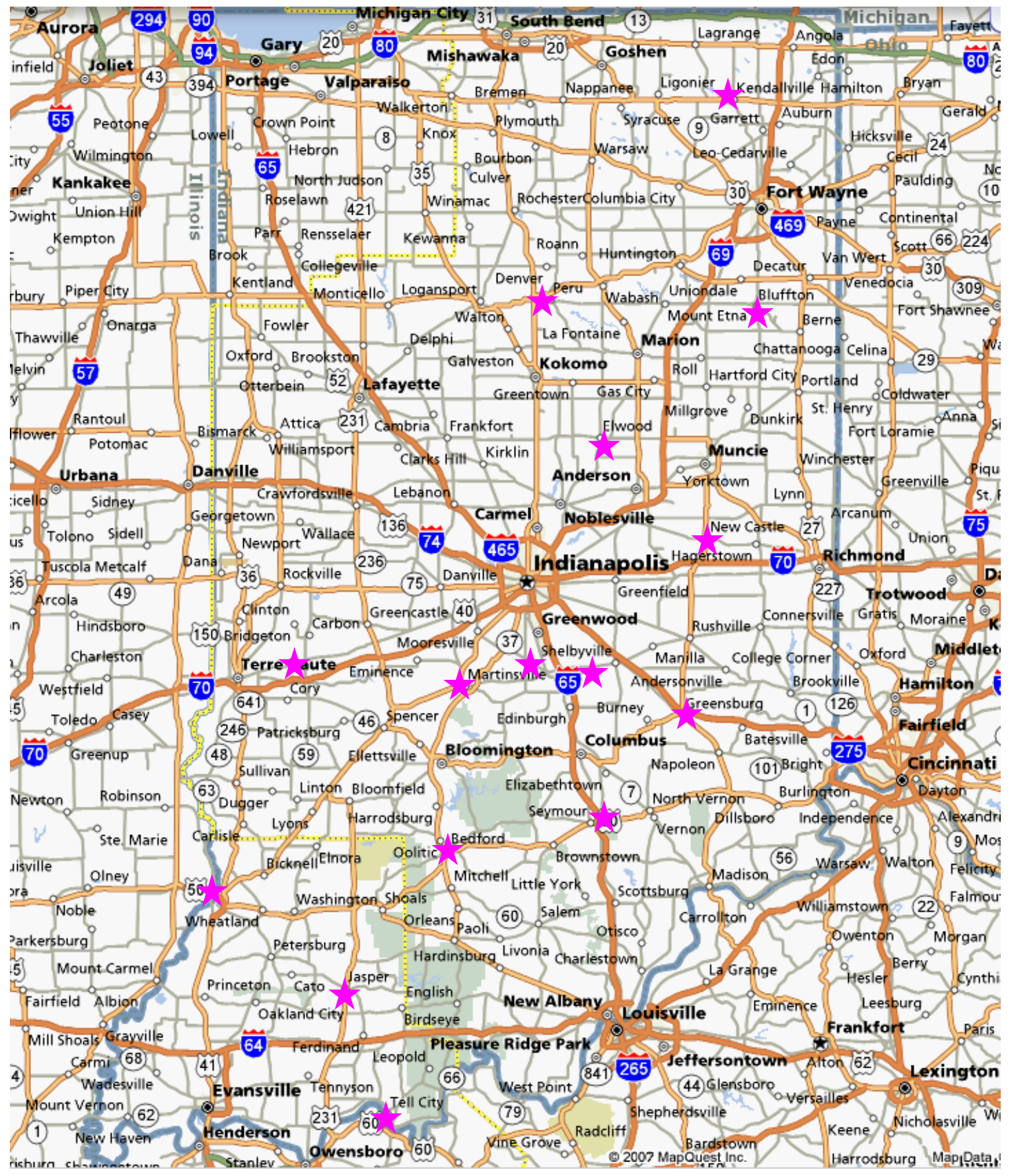

Figure 4.1- Locations of Cities Used for Logit Model Calibration

Following the selection of cities to be used in the logit model estimation, a through trip table was obtained for each one by performing TransCAD subarea analysis and balancing the total number of trips at each origin and destination to the AADT. Each 
station that had less than 3 percent of traffic destined to it and did not have AADT information was excluded from that analysis. In this case, the trips destined to this station were redistributed between the remaining stations based on their relative trip percentages. Furthermore, if any station had AADT information, but the AADT predicted by TransCAD subarea procedure was less than one third of the actual AADT, that station was also omitted. It is believed that, when such a large discrepancy exists between the TransCAD and actual AADT, TransCAD travel patterns to and from this station are not reliable.

The next step in estimating the logit model was choosing the factors that could influence the through trip probabilities. The parameters hypothesized to be important included area population, employment, average annual daily traffic, truck percentage, nearby major city, number of lanes and road classification of the destination station, as well as the route continuity factor for each pair of stations. These factors, as well as the through trip percentages as obtained from TransCAD subarea analysis, are described in Appendix B.

\subsection{Model Estimation}

The software selected to estimate the logit model was LIMDEP 7.0, which enables estimation of model parameter coefficients, corresponding t-statistics, and goodness of fit measures. The procedure for model estimation includes reading in dependent and independent variables, selecting parameters to include in the utility function, and evaluating the goodness of fit of different models. (See Appendix C for LIMDEP input.)

The variable creation process starts off with the independent variable. In this case

the dependent variable is the through trip percentage between a pair of origin and destination stations or the probability of choosing a specific destination station, given that the vehicle entered at some origin station. Thus, despite each pair of stations having one 
line of input, the entire set of destination stations for a particular origin station is considered to be one observation (Appendix B). The dataset used in this modeling procedure consists of: 2 cities with 3 external stations, 2 cities with 4 stations, 7 cities with 5 external stations, 2 cities with 6 external stations, 1 city with 7 cordon stations, and 1 city with 8 external stations, thus creating 76 observations. After setting the dependent variable, the other parameters, which will allow the prediction of the dependent variable, are included in the variable list.

\subsubsection{Parameter Selection}

The next step in the estimation of the logit model involves selection of a utility function that would best describe the probability of selecting a destination station. This involves selecting a set of parameters believed to influence the choice of a destination. While some factors may not be significant in the final model, it is important to test all parameters that could potentially affect the dependent variable to avoid biased parameter estimates. The parameters included in this analysis are those mentioned in previous studies (Modlin's (Martin and McGuckin, 1998) and Anderson's (Anderson et al., 2006))

as well as new ones. Typically, there are two categories of factors that may affect the travel decisions: roadway characteristics at the origin and destination stations, and economic and residential characteristics of the community (and possibly of neighboring communities). In addition, the trip estimation method proposed by Horowitz and Patel (1999) included topological barriers to travel (lakes and mountains) that could affect the trip decisions. However, these factors are considered less important in Indiana and will not be considered.

\section{AADT}

The first parameter, which was included in all the previous methods for estimating an origin-destination trip table, is AADT. In the first step of the Modlin's method AADT had a direct effect on the percentage of through trips at an origin station. 
An increase in the volume of vehicles at the origin station increased the percentage of through trips at that origin. In the second step, a higher proportion of AADT at a destination station as compared to all other destinations increased the through trips to that station. Meanwhile, in Anderson's model, higher AADT at the destination station was found to decrease the propensity of vehicles to travel to that station. While having a different effect on the probability of choosing a destination station, AADT was determined to be a significant parameter in both studies and thus will be included in the logit analysis.

\section{Road Class}

In his analysis, Modlin found that the road classification, such as interstate principal arterial and minor arterial, played a large role in the through trip percentages. Furthermore, he proposed using different equations for estimating the trip distribution for different road classes. Anderson did not find this parameter to be useful, possibly because his analysis excluded cities with interstates or the effect of the road class was captured to some extent by the number of lanes and AADT parameters. In this study, there are no communities with interstates, however, other road classes will be considered in the analysis.

\section{Percentage of Trucks}

The percentage of trucks measured at an external station was another parameter that Modlin found to be important in the estimation of through trips. According to his research, a higher percentage of trucks increased the through trips at an origin station. This is explained by the fact that most truck trips are long-haul and are less likely to have a destination within the community compared to the auto trips.

\section{Route Continuity}

Another prominent parameter in previous analyses is route continuity between an origin and destination station. Both Modlin's and Anderson's methods use route continuity to determine the trip distribution between external stations. However, neither 
author clearly defines what constitutes a "continuous" route. While it is difficult to entirely eliminate subjectivity in defining this parameter, some guidelines are possible. A route can be considered to be continuous if either condition 1 or condition 2 is satisfied:

1. Origin and destination stations both lie on the same road (i.e., both are located on SR9)

OR

2. Turning movement counts or knowledge of the traffic patterns suggest that there are many vehicles traveling between origin station $\mathrm{i}$ and destination station $\mathrm{j}$.

In the absence of local knowledge, condition 2 can be replaced with the condition: the destination station lies on a route that has an interchange with the route that the origin station is located on, and the route that the destination station is located on has a similar alignment to the route with the origin station. For example, in Figure 3.6, the route between a station located on SR-56 and one located on SR-164 could be considered continuous. 


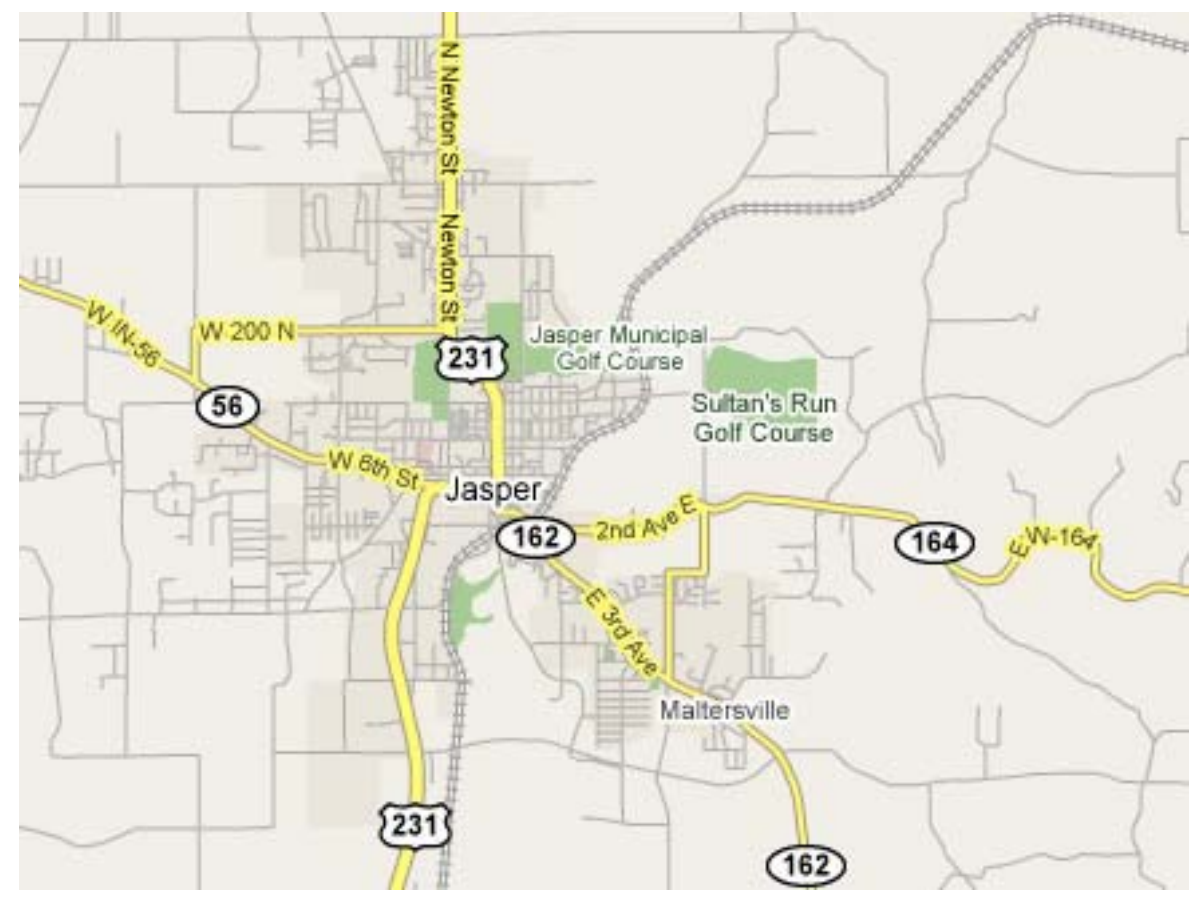

Figure 4.2- Example of a Continuous Route

\section{Number of Lanes}

An additional factor describing the roadway at the origin and destination stations is number of lanes. Anderson included this factor in the analysis, but found it to be insignificant, probably due to high correlation with AADT or roadway class.

\section{Population}

The first factor that influences number of vehicles that have a destination within a community is the community's population. It has been shown that the size of the city directly influences the number of attractions within it, thus resulting in an increase in external-internal trips with an increasing population. Modlin also found this factor to be important in determining through trips. Anderson's analysis, however, omitted this factor, possibly due to lack of variability in the sample data (all the cities used for model estimation had a population between 7,174 and 15,143). It is unclear whether this factor 
will be useful in this study, where the population ranges from 5,000 to 30,000, but it will be included nonetheless.

\section{Nearby Major Center}

In an attempt to incorporate the economic impact of neighboring communities on the travel patterns, Anderson's method included a variable corresponding to the presence of a nearby major center. Presence of such a center on any route leading from the study community would increase the percentage of through trips traveling to the destination station on that route. This predictor, as with the route continuity factor, was not well defined. It was supposed to be estimated based on local knowledge of the area. For example, a small city with a hospital located near a community without one could be considered a nearby major center. In model evaluation performed in this study, no specialized knowledge of the area was available to the researcher and thus an objective measure was used. A nearby major center variable was set to 1 for a destination station if the route on which the destination station was located directly connected to a city larger than the study community. The city was also required to lie within 20 miles or approximately 30 minutes away from the destination station.

\section{Employment}

A parameter not previously considered by either Modlin or Anderson in their analyses is employment within the city. As with population, higher employment may result in an increased percentage of external-internal trips. The employment data was

obtained from the U.S. Census (U.S. Census Bureau, 2000) (Table 4.2). In addition to employment in the city, the number of employees who work in the city, but live outside could be a useful predictor. The hypothesis is that, in communities with more commuters, the external-internal trips will comprise a larger fraction of all trips. 
Table 4.2- Employment Data

\begin{tabular}{|l|r|r|}
\hline City & Employment & Commuters \\
\hline Greensburg & 7,498 & 4,535 \\
\hline Washington & 5,318 & 2,681 \\
\hline Martinsville & 6,705 & 4,137 \\
\hline Jasper & 17,106 & 12,286 \\
\hline Peru & 7,236 & 3,923 \\
\hline Bedford & 10,578 & 7,230 \\
\hline Elwood & 2,794 & 1,517 \\
\hline Bluffton & 8,076 & 5,099 \\
\hline Tell City & 3,554 & 1,813 \\
\hline Brazil & 3,554 & 2,373 \\
\hline Kendallville & 8,055 & 5,468 \\
\hline Shelbyville & 12,490 & 7,341 \\
\hline Vincennes & 12,418 & 6,464 \\
\hline Seymour & 15,268 & 9,493 \\
\hline New Castle & 8,417 & 4,629 \\
\hline Franklin & 10,770 & 7,015 \\
\hline
\end{tabular}

\subsubsection{Model Structure}

As mentioned previously, a logit model requires the specification of a utility function. If the effect of the parameters on all the choices is perceived to be the same, a single utility function is selected and used for all the choices. However, if the effect of a predictor could be different, depending on the option in the choice set, separate utility functions could be used for each of the options. In this study, it is expected that the external-internal trips and the external-external trips from the same origin station to similar destination stations would be significantly different. This external-internal trip effect can be captured by including an external-internal factor in the common utility function. This would result in the total utility for a pair of stations being equal to the external-external utility (which depends on the station characteristics) plus a constant if the trip is internal-external. An alternative way of dealing with the external-internal trips is specifying the external-internal utility function different from the external-external utility function. This would allow the parameters to have a different effect on the external-internal trips and through trips. Furthermore, if a single utility function is used for all the trips, factors that do not vary across alternatives cannot be included 
(Washington et al., 2003). An example is when population and employment are the same for the entire community in question. This occurs because factors that do not vary across outcomes can only be included in I-1 utility functions (where I is the total number of outcomes). If only one utility function is specified, this is not feasible. Meanwhile, if the separate utility functions are used for estimation, these factors can be included.

Despite the shortcomings of the single utility function described above, it was estimated for the sake of completeness of the analysis. First, a function that includes all variables believed to be important is selected, as shown in equation 4.1.

$U=\beta_{0}+\beta_{1} * A A D T_{j}+\beta_{2} * P A_{j}+\beta_{3} * R T E C O N_{i j}+\beta_{4} * N L_{j}+\beta_{5} * N M C_{j}+\beta_{6} * I E F_{j}+\beta_{7} * P T_{j}$

eq. 4.1

The model coefficients are described in Table 4.3.

Table 4.3- Logit Model with all Variables Included

\begin{tabular}{|c|l|c|c|}
\hline Variable & Definition & Coefficient & T-statistic \\
\hline Constant $\left(\beta_{0}\right)$ & & 2.30 & 0.470 \\
\hline AADTj $\left(\beta_{1}\right)$ & AADT at destination station j & $0.684 \times 10^{-4}$ & 1.483 \\
\hline PAj $\left(\beta_{2}\right)$ & $\begin{array}{l}\text { Station j is located on a } \\
\text { principal arterial }\end{array}$ & -0.101 & -0.192 \\
\hline RTECONij $\left(\beta_{3}\right)$ & $\begin{array}{l}\text { Route Continuity Factor } \\
\text { between stations i and j }\end{array}$ & 1.30 & 2.977 \\
\hline $\operatorname{NLj}\left(\beta_{4}\right)$ & $\begin{array}{l}\text { Number of lanes at } \\
\text { destination station j }\end{array}$ & -0.163 & -0.057 \\
\hline $\operatorname{NMCj}\left(\beta_{5}\right)$ & $\begin{array}{l}\text { Nearby Major Center at } \\
\text { destination station j }\end{array}$ & -0.211 & -0.401 \\
\hline $\operatorname{IEFj}\left(\beta_{6}\right)$ & $\begin{array}{l}\text { Internal External Factor }(0 \text { for } \\
\text { external-external stations) }\end{array}$ & 2.90 & 8.181 \\
\hline $\operatorname{PTj}\left(\beta_{7}\right)$ & $\begin{array}{l}\text { Percent Trucks at destination } \\
\text { station j }\end{array}$ & -1.06 & -0.211 \\
\hline
\end{tabular}

Evaluation of the goodness of fit of the logit model cannot be done by using the $\mathrm{R}$-squared value, because the model is not linear. Instead, log likelihood (Washington et al., 2003, p. 73), which LIMDEP aims to maximize when estimating the best model, will be the statistic used for model comparison. The log likelihood resulting from running the 
model with the utility function described in equation 4.1 is -72.06 . Meanwhile, the $\log$ likelihood with no coefficients is -166.99 . Another measure of the model fit is the $\rho^{2}$ statistic (equation 4.2), which is the equivalent of the R-squared parameter for logit models. The same parameter, adjusted to take into account the number of variables included in the model, is described in equation 4.3 .

$$
\begin{aligned}
& \rho^{2}=1-\frac{\operatorname{LL}(\beta)}{\operatorname{LL}(0)} \\
& \rho_{\text {adj }}^{2}=1-\frac{\operatorname{LL}(\beta)-K}{\operatorname{LL}(0)}
\end{aligned}
$$

where

$\operatorname{LL}(\beta)=\quad \log$ Likelihood at convergence with parameter vector $\beta$

$\mathrm{LL}(0)=\quad \log$ likelihood with all parameters set to 0

$\mathrm{K}=$ number of estimated parameters

The resulting $\rho^{2}$ statistic was 0.57 and the adjusted $\rho^{2}$ statistic was 0.55 .

In addition to searching for the model with the highest log likelihood, it is important to include only the relevant variables in the model. The most appropriate test statistic for a multinomial logit model, which is derived from an extreme value distribution, is the likelihood ratio described in equation 4.4. This statistic is distributed with the number of degrees of freedom equal to the difference in number of parameters in $\beta_{\mathrm{R}}$ and $\beta_{\mathrm{U}}$ vectors. This test should be performed after each variable is added to determine whether it is significant.

$$
\chi^{2}=2\left[L L\left(\beta_{R}\right)-L L\left(\beta_{U}\right)\right]
$$

where

$L L\left(\beta_{R}\right)=\quad \log$ likelihood at convergence of the "restricted" model

$L L\left(\beta_{U}\right) \quad=\quad \log$ likelihood at convergence of the "unrestricted" model 
The more common test that serves as a good approximation to the likelihood ratio test is the t-statistic, described in equation 4.5. The t-statistic allows a test of the hypothesis that the parameter is significantly different from zero. For example, if one would like to know with 90 percent confidence that the parameter is different from 0 , the t-statistic of that parameter would need to exceed 1.7.

$$
\mathrm{t}=1-\frac{\beta-0}{\operatorname{S.E} .(\beta)}
$$

where

$\beta=$ parameter vector $\beta$, and

S.E. $=$ standard error of the parameter

The t-statistics for the parameters used in the model are presented in Table 4.3. It is evident that many of the factors have low t-statistics, indicating that it is not likely that they are different from zero and can be rejected. Due to the limited number of observations (76) available for model estimation, a t-statistic exceeding 1.6 (corresponding to 90 percent confidence) will be considered acceptable.

After a few other trial runs of the model with different parameters, it was evident that the factors significant to the route choice are AADT, route continuity and internalexternal factor. The resulting model is described in eq. 4.6.

$$
\mathrm{U}=\left(0.588 \times 10^{-4} * \mathrm{AADT}_{\mathrm{j}}\right)+\left(1.302 * \mathrm{RTECON}_{\mathrm{ij}}\right)+(2.916 * \mathrm{IEF})
$$

The log likelihood of the converged model decreased slightly, from -71.68 to -72.06 , with a corresponding $\rho^{2}$ statistic of 0.57 and an adjusted $\rho^{2}$ statistic of 0.55 . The tstatistics for all the variables exceeded 1.6, which implies that the parameters are significant at the 90 percent confidence level (Table 4.4). 
Table 4.4- Logit Model with only Relevant Variables

\begin{tabular}{|c|c|c|c|}
\hline Variable & Coefficient & T-statistic & P-Value \\
\hline AADT & $0.588 \times 10^{-4}$ & 1.722 & 0.0850 \\
\hline RTECON & 1.302 & 2.978 & 0.0029 \\
\hline IEF & 2.916 & 8.227 & 0.0000 \\
\hline
\end{tabular}

As mentioned previously, separate utility functions for the external-external and external-internal trips can improve the model's predicting capabilities and include additional explanatory variables. The separate utility functions can be written as:

$$
\begin{aligned}
& U_{I E}=\beta^{I E} * X+Z^{I E} * X \\
& U_{E E}=\beta^{E E} * X \\
& \beta^{I E}=\left[\begin{array}{llllll}
\beta_{0}^{I E} & \beta_{1}^{I E} & \beta_{2}^{I E} & \beta_{3}^{I E} & \beta_{4}^{I E} & \beta_{5}^{I E}
\end{array}\right] \\
& Z^{I E}=\left[\beta_{7}^{I E} \beta_{8}^{I E}\right] \\
& \beta^{E E}=\left[\beta_{1}^{I E} \beta_{2}^{I E} \beta_{3}^{I E} \beta_{4}^{I E} \beta_{5}^{I E} \beta_{6}^{I E}\right]
\end{aligned}
$$

with the variable definitions given in Table 4.5. The model evaluation results for all variables are shown in Table 4.5.

Table 4.5- Two-Utility Function Logit Model with all Variables Included

\begin{tabular}{|c|l|c|c|}
\hline Variable & Definition & Coefficient & T-statistic \\
\hline Constant $\left(\beta_{0}\right)$ & & 4.38 & 3.475 \\
\hline $\operatorname{AADT}\left(\beta_{1}^{I E}\right)$ & $\begin{array}{l}\text { AADT at destination station } \\
\mathrm{j}\end{array}$ & $0.618 \times 10^{-4}$ & 0.483 \\
\hline $\mathrm{PA}\left(\beta_{2}^{I E}\right)$ & $\begin{array}{l}\text { Station j is located on } \mathrm{a} \\
\text { principal arterial }\end{array}$ & -0.414 & -0.562 \\
\hline $\mathrm{NL}\left(\beta_{3}^{I E}\right)$ & $\begin{array}{l}\text { Number of lanes at } \\
\text { destination station j }\end{array}$ & -0.121 & -0.291 \\
\hline $\mathrm{NMC}\left(\beta_{4}^{I E}\right)$ & $\begin{array}{l}\text { Nearby Major Center at } \\
\text { destination station j }\end{array}$ & -0.261 & -0.298 \\
\hline $\operatorname{PT}\left(\beta_{5}^{I E}\right)$ & $\begin{array}{l}\text { Percent Trucks at } \\
\text { destination station j }\end{array}$ & -3.06 & -0.535 \\
\hline AADT $\left(\beta_{1}^{E E}\right)$ & $\begin{array}{l}\text { AADT at destination station } \\
\mathrm{j}\end{array}$ & $0.856 \times 10^{-4}$ & 1.648 \\
\hline
\end{tabular}




\begin{tabular}{|c|l|c|c|}
\hline $\operatorname{PA}\left(\beta_{2}^{E E}\right)$ & $\begin{array}{l}\text { Station j is located on a } \\
\text { principal arterial }\end{array}$ & 0.391 & 0.522 \\
\hline $\mathrm{NL}\left(\beta_{3}^{E E}\right)$ & $\begin{array}{l}\text { Number of lanes at } \\
\text { destination station j }\end{array}$ & $0.143 \times 10^{-1}$ & 0.042 \\
\hline $\mathrm{NMC}\left(\beta_{4}^{E E}\right)$ & $\begin{array}{l}\text { Nearby Major Center at } \\
\text { destination station j }\end{array}$ & -0.116 & -0.160 \\
\hline $\mathrm{PT}\left(\beta_{5}^{E E}\right)$ & $\begin{array}{l}\text { Percent Trucks at } \\
\text { destination station j }\end{array}$ & $-0.867 \times 10^{-1}$ & -0.017 \\
\hline $\mathrm{RTECONij}\left(\beta_{6}^{E E}\right)$ & $\begin{array}{l}\text { Route Continuity Factor } \\
\text { between stations i and j }\end{array}$ & 1.15 & 2.524 \\
\hline $\operatorname{POP}\left(\beta_{7}^{I E}\right)$ & Population in the city & $-0.281 \times 10^{-4}$ & -0.285 \\
\hline $\operatorname{EMP}\left(\beta_{8}\right)$ & Employment in the city & $0.581 \times 10^{-4}$ & 0.585 \\
\hline
\end{tabular}

After manipulating the set of parameters that affect the choice of destination, the variables that most affect this decision were determined to be route continuity and proportion of $A A D T$ for through trips. For external-internal trips, none of the variables were significant, but the constant value of 3.78 led to a good model fit. The two resulting utility functions are given in eq. 4.7.

$$
\begin{aligned}
& \mathrm{U}(\mathrm{EI})=3.78 \\
& \mathrm{U}(\mathrm{EE})=\left(1.177 * \mathrm{RTECON}_{\mathrm{ij}}\right)+\left(4.448 * \frac{\mathrm{AADT}_{\mathrm{j}}}{\sum \mathrm{AADT}_{\mathrm{j}}}\right)
\end{aligned}
$$

The log likelihood is equal to -70.66 . The $\rho^{2}$ statistic is 0.58 . The t-statistics for the parameters are shown in Table 4.6.

Table 4.6- Logit Model with Two Utility Functions

\begin{tabular}{|c|c|c|c|}
\hline Variable & $\begin{array}{c}\text { Function } \\
\text { where used }\end{array}$ & Coefficient & T-statistic \\
\hline Constant & U(EI) & 3.78 & 7.260 \\
\hline RTECONij & U(EE) & 1.177 & 2.740 \\
\hline AADTj/sum (AADTj) & U(EE) & 4.448 & 2.491 \\
\hline
\end{tabular}

This model describes the data better than the single utility function model because it has higher log likelihood and model fit statistics. All the variables included are also relevant if we use the cutoff $t$-statistic of 1.6 that corresponds to a 90 percent confidence 
interval. As explained previously, the t-statistic is not set higher because of the limited number of observations.

The parameters found to be significant in the model are readily explained. The constant has a large positive value, because in most cities, internal-external trips comprise the majority of all trips that cross the cordon line. Route continuity between an origin and destination station increases the probability that the driver will select that route rather than a non-continuous one. This is consistent with the definition and the researcher's expectations. The value of the third parameter is also easily explained. An increase in the relative value of AADT at a destination station, as compared to all the destination stations, increases the propensity of the driver to choose that route. This occurs because the higher AADT corresponds to a more significant route in the network, which draws more vehicles.

\subsubsection{Model Assumption Verification}

The last step in ensuring that the model is statistically sound is verifying the underlying assumptions and checking for possible specification errors. One of the most important assumptions in the context of a multinomial logit model is the Independence of Irrelevant Alternatives (IIA) property. If some, but not all, of the alternatives share unobserved effects, their disturbances are no longer independently and identically distributed, thus violating an important derivation assumption (Washington et al., 2003). The proposed model was suspected to suffer from this violation because it is plausible that all the external-external trips share some effects not captured by the utility function. Because the data was available only in percentages, it was not possible to conduct a formal Small-Hsiao test, which is recommended (Washington et al., 2003). Instead, a nested logit structure, shown in Figure 4.3, was tested. 


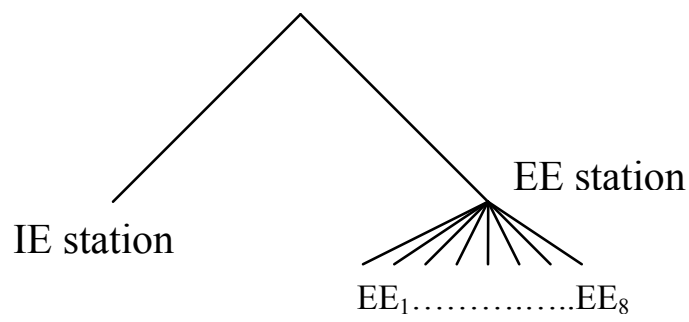

Figure 4.3- Nested Logit Structure

Upon testing various parameters and their combinations in the top utility function, which splits trips into internal-external and external-external, no parameter was found to be significant. Therefore, the nested logit structure is not necessary and the IIA property is not violated.

\subsubsection{Parameter elasticities}

The next question regarding the proposed model concerns the sensitivity of the model results to the variables included in the model, which are "route continuity' and "percentage of AADT". While the direct elasticity of the route continuity factor cannot be evaluated because it is an indicator variable, the effect of changing this variable from 0 to 1 can be estimated using the marginal effects command in LIMDEP. The analysis shows that, if the route continuity is changed from 0 to 1 while holding all the other parameters constant at their average values, the percentage of trips between an origin and a destination increases by 23 percent.

\subsection{Application of Logit Model to Greenfield}

After calibrating the model and verifying its assumptions, the next step is to evaluate it using the origin-destination matrix for the city of Greenfield. The through trip percentages between each pair of stations in Greenfield were estimated using the AADT 
data from section 3.1. Then, the trips were calculated, made symmetrical and balanced to the AADT analogously to Modlin's method (Table 4.7). Finally, the through trip percentages were recalculated using through trip distribution numbers (Table 4.8).

Table 4.7- Greenfield Through Trip Distribution using Logit Model

\begin{tabular}{|l|r|r|r|r|r|r|}
\hline & \multicolumn{7}{|c|}{ Destination } \\
\hline Origin & SR-9 N & I-70 W & US-40 W & SR-9 S & US-40 E & I-70 E \\
\hline SR-9 N & 3412 & 571 & 228 & 429 & 155 & 209 \\
\hline I-70 W & 570 & 6505 & 397 & 500 & 271 & 185 \\
\hline US-40 W & 228 & 397 & 5499 & 196 & 745 & 158 \\
\hline SR-9 S & 429 & 501 & 196 & 2818 & 133 & 91 \\
\hline US-40 E & 155 & 271 & 746 & 133 & 3509 & 107 \\
\hline I-70 E & 209 & 185 & 158 & 91 & 107 & 2129 \\
\hline
\end{tabular}

Table 4.8- Greenfield Through Trip Percentages using Logit Model

\begin{tabular}{|l|r|r|r|r|r|r|}
\hline & \multicolumn{7}{|c|}{ Destination } \\
\hline Origin & SR-9 N & I-70 W & US-40 W & \multicolumn{1}{|c|}{ SR-9 S } & US-40 E & I-70 E \\
\hline SR-9 N & $68.18 \%$ & $11.40 \%$ & $4.55 \%$ & $8.58 \%$ & $3.11 \%$ & $4.18 \%$ \\
\hline I-70 W ramp & $6.76 \%$ & $77.18 \%$ & $4.71 \%$ & $5.93 \%$ & $3.21 \%$ & $2.20 \%$ \\
\hline US-40 W & $3.15 \%$ & $5.50 \%$ & $76.14 \%$ & $2.71 \%$ & $10.32 \%$ & $2.18 \%$ \\
\hline SR-9 S & $10.30 \%$ & $12.01 \%$ & $4.70 \%$ & $67.61 \%$ & $3.20 \%$ & $2.18 \%$ \\
\hline US-40 E & $3.16 \%$ & $5.51 \%$ & $15.15 \%$ & $2.71 \%$ & $71.31 \%$ & $2.17 \%$ \\
\hline I-70 E ramp & $7.26 \%$ & $6.44 \%$ & $5.48 \%$ & $3.15 \%$ & $3.72 \%$ & $73.94 \%$ \\
\hline
\end{tabular}

\subsection{Evaluation of the Effectiveness of Logit Model}

The plot of predicted trips versus actual trips (Figure 4.1) indicates better adherence than either Modlin's (Figure 3.2) or Anderson's method (Figure 3.3). The average errors in the percentages of IE and EE trips are 2.1 percent and -15 percent respectively. The RMSE is 7.0 percent, which is very close to that obtained in subarea analysis. 


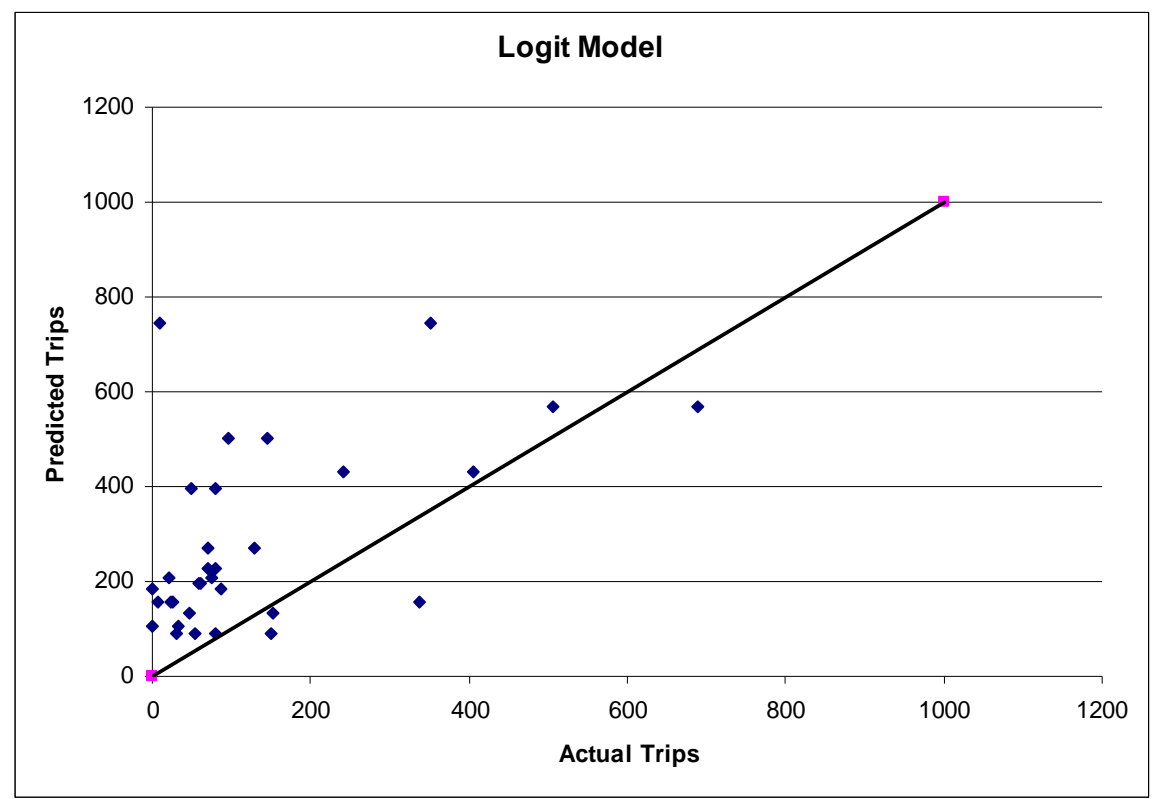

Figure 4.4- Logit Model Trips Predicted by Logit Model versus Actual Trips

\subsection{Summary}

As explained in this chapter, the logit model has some clear advantages over Modlin's and Anderson's methods. The logit model is more appropriate when modeling choicebased decision from a statistical viewpoint. In addition, the model specified in the chapter provides guidelines for selecting a route continuity factor and explains the effect of the parameters important in the determination of the through trips. The effectiveness of the logit model is demonstrated using Greenfield origin-destination data. The model's performance is similar to subarea analysis and significantly better that Modlin's and Anderson's methods (Table 4.9). Overall, logit model is a simple (it uses only two parameters) and effective tool in estimation of through trips.

Table 4.9- Model Performance Comparison using Greenfield Data

\begin{tabular}{|l|r|r|r|r|r|}
\hline & EE Trips & \multicolumn{1}{|c|}{ IE Trips } & EE Trip \% & IE Trip \% & \multicolumn{1}{l|}{ RMSE } \\
\hline Modlin's Method & 290 & -1531 & $5.27 \%$ & $-26.35 \%$ & $12.4 \%$ \\
\hline Anderson's Method & 425 & -2203 & $8.14 \%$ & $-40.71 \%$ & $18.7 \%$ \\
\hline Subarea Analysis & 134 & -748 & $1.96 \%$ & $-10.9 \%$ & $7.75 \%$ \\
\hline Logit Model & 155 & -854 & $2.14 \%$ & $-14.8 \%$ & $7.0 \%$ \\
\hline
\end{tabular}




\section{CHAPTER 5. APPLICATION OF THE ESTIMATION METHODS LAPORTE}

The second dataset that can be used to evaluate Modlin's and Anderson's models, subarea analysis, and the logit model is from LaPorte, Indiana. Similar to Greenfield, a vehicle license plate origin destination survey was conducted for this city. The survey was done as a part of economic development corridor feasibility study completed by Bernardin-Lochmueller and Associates Inc (2007). The analysis area, including the external stations, is shown in Figure 5.1. The list of station numbers with corresponding locations is presented in Table 5.1.

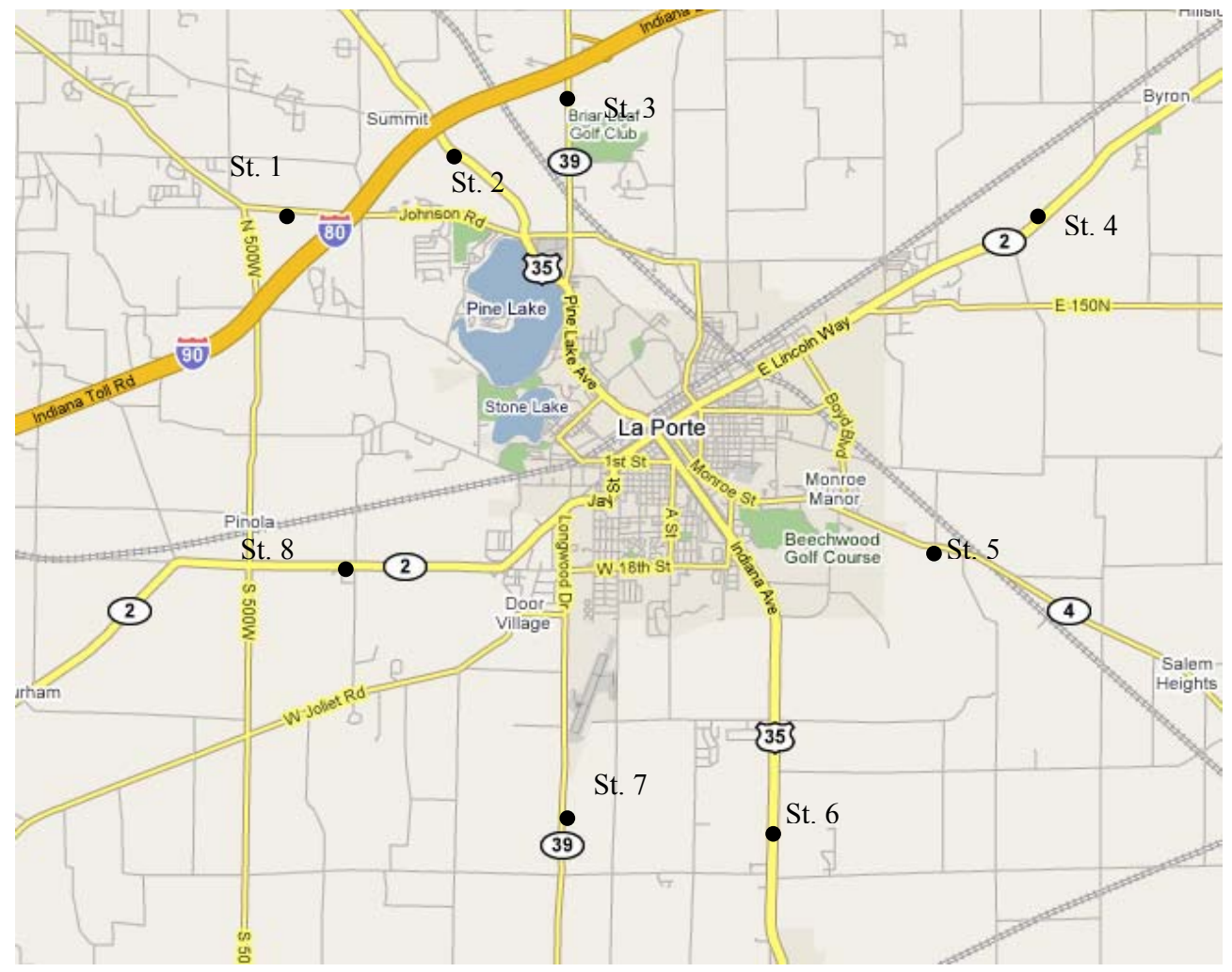

Figure 5.1- LaPorte Area 
Table 5.1- External Stations in LaPorte

\begin{tabular}{|c|l|}
\hline Station number & Location \\
\hline 1 & Johnson Rd. west of Toll Rd. \\
\hline 2 & US-35 south of Toll Rd. \\
\hline 3 & SR-39 south of Toll Rd. \\
\hline 4 & SR-2 west of Lofgren Rd. \\
\hline 5 & SR-4 west of CR-200 E \\
\hline 6 & US-35 south of CR-300 S \\
\hline 7 & SR-39 south of CR-250 S \\
\hline 8 & SR-2 west of CR-500 W \\
\hline
\end{tabular}

The origin destination matrix that was obtained from the vehicle license plate survey is shown in Table 5.2. The corresponding percentages from each origin to each of the destinations are given in Table 5.3.

Table 5.2- LaPorte External-External and External-Internal Trip Matrix

\begin{tabular}{|l|l|l|l|l|l|l|l|l|}
\hline & $\begin{array}{l}\text { John- } \\
\text { son }\end{array}$ & US35 N & SR39 N & SR2 W & SR4 E & US35 S & SR39 S & SR2 E \\
\hline Johnson & 3950 & 0 & 0 & 0 & 0 & 0 & 0 & 0 \\
\hline US-35 N & 0 & 4650 & 44 & 32 & 64 & 111 & 12 & 7 \\
\hline SR-39 N & 0 & 44 & 3071 & 24 & 37 & 45 & 8 & 12 \\
\hline SR-2 W & 0 & 32 & 24 & 5226 & 41 & 88 & 25 & 63 \\
\hline SR-4 E & 0 & 64 & 37 & 41 & 2786 & 21 & 3 & 22 \\
\hline US-35 S & 0 & 111 & 45 & 88 & 21 & 4785 & 20 & 4 \\
\hline SR-39 S & 0 & 12 & 8 & 25 & 3 & 20 & 1475 & 13 \\
\hline SR-2 E & 0 & 7 & 13 & 63 & 22 & 4 & 13 & 3842 \\
\hline
\end{tabular}

Table 5.3- LaPorte EE and EI Trip Percentages

\begin{tabular}{|l|r|r|r|r|r|r|r|r|}
\hline & $\begin{array}{l}\text { John- } \\
\text { son }\end{array}$ & US35 N & SR39 N & SR2 W & SR4 E & US35 S & SR39 S & SR2 E \\
\hline Johnson & $100.0 \%$ & $0.00 \%$ & $0.00 \%$ & $0.00 \%$ & $0.00 \%$ & $0.00 \%$ & $0.00 \%$ & $0.00 \%$ \\
\hline US-35 N & $0.00 \%$ & $93.70 \%$ & $0.98 \%$ & $0.69 \%$ & $1.46 \%$ & $2.76 \%$ & $0.27 \%$ & $0.13 \%$ \\
\hline SR-39 N & $0.00 \%$ & $1.45 \%$ & $93.34 \%$ & $0.80 \%$ & $1.31 \%$ & $2.30 \%$ & $0.43 \%$ & $0.37 \%$ \\
\hline SR-2 W & $0.00 \%$ & $0.61 \%$ & $0.47 \%$ & $94.13 \%$ & $0.71 \%$ & $2.08 \%$ & $0.57 \%$ & $1.42 \%$ \\
\hline SR-4 E & $0.00 \%$ & $2.58 \%$ & $1.56 \%$ & $1.42 \%$ & $92.71 \%$ & $0.88 \%$ & $0.10 \%$ & $0.75 \%$ \\
\hline US-35 S & $0.00 \%$ & $2.70 \%$ & $1.53 \%$ & $2.32 \%$ & $0.49 \%$ & $92.46 \%$ & $0.42 \%$ & $0.08 \%$ \\
\hline SR-39 S & $0.00 \%$ & $0.88 \%$ & $0.94 \%$ & $2.14 \%$ & $0.19 \%$ & $1.38 \%$ & $93.58 \%$ & $0.88 \%$ \\
\hline SR-2 E & $0.00 \%$ & $0.16 \%$ & $0.30 \%$ & $1.94 \%$ & $0.51 \%$ & $0.09 \%$ & $0.32 \%$ & $96.67 \%$ \\
\hline
\end{tabular}




\subsection{Modlin's Method}

\subsubsection{Data}

The data required for Modlin's analysis includes the AADT at each station, road class, percentage of trucks, percentage of vans and pickups, population and route continuity factors.

\section{AADT}

The average annual daily traffic counts were obtained from the report done by Bernardin-Lochmueller and Associates Inc ((Bernardin-Lochmueller and Associates Inc., 2007). These were collected at all external stations in 2006 and are summarized in Table 5.4 .

Table 5.4- LaPorte External Station Daily Counts

\begin{tabular}{|l|r|r|r|r|r|r|r|r|}
\hline & Johnson & US35 N & SR39 N & SR2 W & SR4 E & US35 S & SR39 S & \multicolumn{1}{|c|}{ SR2 E } \\
\hline Auto & 7898 & 9300 & 6142 & 10452 & 5572 & 9570 & 2950 & 7684 \\
\hline AADT & 8252 & 10376 & 7030 & 11826 & 5898 & 10534 & 3180 & 8646 \\
\hline
\end{tabular}

\section{Road Class}

All the roads where the external stations are located were classified in the LaPorte report into interstate, major arterial, minor arterial, major collector, minor collector and locals. The principal arterials were described as those complementing the interstate system by serving through traffic in metropolitan areas, while the minor arterial class was said to distribute traffic to smaller geographic areas and link smaller cities and towns to form an integrated network. The road classification employed by Modlin's method only includes three road classifications (interstate, major arterial, and minor arterials). Consequently, both principal arterials and minor arterials as classified in the report were assumed to be principal arterials for the purpose of this analysis. The major and minor collectors were then treated as minor arterials (Table 5.5). 
Table 5.5- LaPorte Road Classification

\begin{tabular}{|l|l|}
\hline Road & Classification \\
\hline Johnson W of Toll Rd & Minor arterial \\
\hline US35 N of Toll Rd & Minor arterial \\
\hline SR39 S of Toll Rd & Principal arterial \\
\hline SR2 W of Lofgren Rd. & Minor arterial \\
\hline SR4 W of CR-200 & Minor arterial \\
\hline US35 S of CR-300 & Principal arterial \\
\hline SR39 S of CR-250 & Minor arterial \\
\hline SR2 E of CR-500 & Principal arterial \\
\hline
\end{tabular}

\section{Percentage of Trucks}

The percentage of trucks was obtained from the LaPorte corridor study and was based on the vehicle classification results (Table 5.6)

Table 5.6- LaPorte Percentage of Trucks

\begin{tabular}{|l|r|r|r|r|r|r|r|r|}
\hline & $\begin{array}{l}\text { John- } \\
\text { son }\end{array}$ & US35 N & SR39 N & SR2 W & SR4 E & US35 S & SR39 S & SR2 E \\
\hline Truck & 354 & 1076 & 888 & 1374 & 326 & 964 & 230 & 962 \\
\hline AADT & 8252 & 10376 & 7030 & 11826 & 5898 & 10534 & 3180 & 8646 \\
\hline $\begin{array}{l}\% \\
\text { trucks }\end{array}$ & $4.29 \%$ & $10.37 \%$ & $12.63 \%$ & $11.62 \%$ & $5.53 \%$ & $9.15 \%$ & $7.23 \%$ & $11.13 \%$ \\
\hline
\end{tabular}

\section{Percentage of Vans and Pickups}

Similar to Greenfield, the data concerning the number of vans and pickups was not available for the LaPorte area. Thus the average percentage of vans and pickup trucks as determined from a WIM station on I-70 was used. The value as mentioned in the Greenfield data section varied between 24 percent and 40 percent with an average value of 31 percent.

\section{Population}

The population residing within the subarea was expected to be higher than just the population of LaPorte because the cordon line used for the analysis was located outside the city. Thus, the population to be used in Modlin's method was calculated by adding 
the population of each census tract within the cordon line. The total number of residents was determined to be 22,383 .

\section{Route Continuity Factor}

The route continuity factor, which is an indicator variable, was set to 1 for a pair of stations lying on the same route. The full matrix of route continuity factors is shown in Table 5.7.

Table 5.7- LaPorte Route Continuity Factor

\begin{tabular}{|l|r|r|r|r|r|r|r|r|}
\hline & \multicolumn{1}{l|}{$\begin{array}{l}\text { John- } \\
\text { Son }\end{array}$} & US35 N & SR39 N & SR2 W & SR4 E & US35 S & SR39 S & \multicolumn{1}{l|}{ SR2 E } \\
\hline Johnson & 0 & 0 & 0 & 0 & 0 & 0 & 0 & 0 \\
\hline US-35 N & 0 & 0 & 0 & 0 & 0 & 1 & 0 & 0 \\
\hline SR-39 N & 0 & 0 & 0 & 0 & 0 & 0 & 1 & 0 \\
\hline SR-2 W & 0 & 0 & 0 & 0 & 0 & 0 & 0 & 1 \\
\hline SR-4 E & 0 & 0 & 0 & 0 & 0 & 0 & 0 & 0 \\
\hline US-35 S & 0 & 1 & 0 & 0 & 0 & 0 & 0 & 0 \\
\hline SR-39 S & 0 & 0 & 1 & 0 & 0 & 0 & 0 & 0 \\
\hline SR-2 E & 0 & 0 & 0 & 1 & 0 & 0 & 0 & 0 \\
\hline
\end{tabular}

\subsubsection{Method}

The method followed in order to calculate the through trips using Modlin's equations is described in section 3.2.2. The first step of the method yields the through trip percentage at each of the origin stations shown in Table 5.8. 
Table 5.8- LaPorte Through Trips using Modlin's Method

\begin{tabular}{|l|r|r|r|}
\hline Station & Percent ext & AADT & Through \\
\hline Johnson Rd. & 13.9 & 8252 & 1146 \\
\hline US-35 N & 17.7 & 10376 & 1840 \\
\hline SR-39 N & 35.1 & 7030 & 2468 \\
\hline SR-2 W & 18.6 & 11826 & 2204 \\
\hline SR-4 E & 14.3 & 5898 & 845 \\
\hline US-35 S & 33.5 & 10534 & 3526 \\
\hline SR-39 S & 15.0 & 3180 & 477 \\
\hline SR-2 E & 34.4 & 8646 & 2975 \\
\hline
\end{tabular}

Calculating the through trip percentage between pairs of stations using equations 3.2 through 3.5 , and balancing them so that all trips from each origin add up to 100 percent, yields Table 5.9.

Table 5.9- LaPorte Through Trip Percent Distribution for LaPorte using Modlin's Method

\begin{tabular}{|l|r|r|r|r|r|r|r|r|}
\hline & \multicolumn{1}{l|}{$\begin{array}{l}\text { John- } \\
\text { son }\end{array}$} & US35 N & SR39 N & SR2 W & SR4 E & US35 S & SR39 S & SR2 E \\
\hline Johnson & $0.00 \%$ & $11.81 \%$ & $20.75 \%$ & $13.67 \%$ & $5.66 \%$ & $22.65 \%$ & $3.79 \%$ & $21.67 \%$ \\
\hline US-35 N & $9.65 \%$ & $0.00 \%$ & $15.80 \%$ & $10.41 \%$ & $4.31 \%$ & $40.47 \%$ & $2.88 \%$ & $16.49 \%$ \\
\hline SR-39 N & $10.35 \%$ & $9.65 \%$ & $0.00 \%$ & $11.17 \%$ & $4.62 \%$ & $18.50 \%$ & $28.02 \%$ & $17.70 \%$ \\
\hline SR-2 W & $9.79 \%$ & $9.12 \%$ & $16.02 \%$ & $0.00 \%$ & $4.37 \%$ & $17.49 \%$ & $2.93 \%$ & $40.29 \%$ \\
\hline SR-4 E & $11.84 \%$ & $11.04 \%$ & $19.39 \%$ & $12.78 \%$ & $0.00 \%$ & $21.16 \%$ & $3.54 \%$ & $20.25 \%$ \\
\hline US-35 S & $10.51 \%$ & $35.11 \%$ & $17.22 \%$ & $11.34 \%$ & $4.69 \%$ & $0.00 \%$ & $3.14 \%$ & $17.98 \%$ \\
\hline SR-39 S & $9.09 \%$ & $8.47 \%$ & $36.78 \%$ & $9.81 \%$ & $4.06 \%$ & $16.25 \%$ & $0.00 \%$ & $15.54 \%$ \\
\hline SR-2 E & $10.43 \%$ & $9.72 \%$ & $17.08 \%$ & $36.36 \%$ & $4.66 \%$ & $18.64 \%$ & $3.12 \%$ & $0.00 \%$ \\
\hline
\end{tabular}

The next step consists of multiplying the through trip percentages by the through trips at each origin (from step 1 of the method), resulting in the through trip distribution shown in Table 5.10. 
Table 5.10- LaPorte Through Trip Distribution for LaPorte using Modlin's Method

\begin{tabular}{|l|r|r|r|r|r|r|r|r|}
\hline & $\begin{array}{l}\text { John- } \\
\text { son }\end{array}$ & US35 N & SR39 N & SR2 W & SR4 E & US35 S & SR39 S & SR2 E \\
\hline Johnson & 0 & 49 & 101 & 58 & 22 & 122 & 6 & 111 \\
\hline US-35 N & 71 & 0 & 88 & 50 & 19 & 276 & 5 & 96 \\
\hline SR-39 N & 123 & 75 & 0 & 88 & 34 & 184 & 305 & 167 \\
\hline SR-2 W & 83 & 50 & 103 & 0 & 23 & 124 & 6 & 312 \\
\hline SR-4 E & 50 & 31 & 63 & 36 & 0 & 76 & 4 & 69 \\
\hline US-35 S & 193 & 582 & 240 & 138 & 53 & 0 & 14 & 263 \\
\hline SR-39 S & 19 & 11 & 69 & 13 & 5 & 28 & 0 & 26 \\
\hline SR-2 E & 154 & 94 & 192 & 482 & 42 & 232 & 11 & 0 \\
\hline
\end{tabular}

After the trips between each pair of origin destination stations are obtained, they are made symmetrical. Then, the total trips at every origin and destination are balanced to the AADT. Note that the bi-directional AADT was not available and the trips were balanced to half of the two-way AADT. In the last step, the external-internal trips were calculated by subtracting the through trips from AADT and added as diagonal entries in the trip matrix (see section 3.2.2).

\subsubsection{Results}

The resulting through trip table is presented in Table 5.11. In addition to the calculation of actual number of trips between stations, it may be useful to express the trips traveling from an origin to a destination as a percentage of all trips from that origin. The trip percentages are detailed in Table 5.12. 
Table 5.11- LaPorte Through and External-Internal Trip Distribution using Modlin's Method

\begin{tabular}{|l|r|r|r|r|r|r|r|r|}
\hline Origins & $\begin{array}{l}\text { John- } \\
\text { Son }\end{array}$ & US35 N & SR39 N & SR2 W & SR4 E & US35 S & SR39 S & SR2 E \\
\hline Johnson & 3553 & 54 & 113 & 75 & 38 & 162 & 11 & 121 \\
\hline US-35 N & 54 & 4268 & 118 & 77 & 39 & 496 & 11 & 125 \\
\hline SR-39 N & 113 & 118 & 2281 & 164 & 83 & 354 & 136 & 266 \\
\hline SR-2 W & 75 & 77 & 164 & 4811 & 53 & 230 & 15 & 488 \\
\hline SR-4 E & 38 & 39 & 83 & 53 & 2526 & 115 & 8 & 87 \\
\hline US-35 S & 162 & 496 & 354 & 230 & 115 & 3504 & 33 & 375 \\
\hline SR-39 S & 11 & 11 & 136 & 15 & 8 & 33 & 1351 & 25 \\
\hline SR-2 E & 121 & 125 & 266 & 488 & 87 & 375 & 25 & 2836 \\
\hline
\end{tabular}

Table 5.12- LaPorte Through and EI Trip Percentages using Modlin's Method

\begin{tabular}{|l|r|r|r|r|r|r|r|r|}
\hline Origins & $\begin{array}{l}\text { John- } \\
\text { son }\end{array}$ & US35 N & SR39 N & SR2 W & SR4 E & US35 S & SR39 S & SR2 E \\
\hline Johnson & $86.11 \%$ & $1.31 \%$ & $2.74 \%$ & $1.82 \%$ & $0.92 \%$ & $3.92 \%$ & $0.25 \%$ & $2.94 \%$ \\
\hline US-35 N & $1.04 \%$ & $82.27 \%$ & $2.28 \%$ & $1.49 \%$ & $0.74 \%$ & $9.55 \%$ & $0.21 \%$ & $2.42 \%$ \\
\hline SR-39 N & $3.21 \%$ & $3.36 \%$ & $64.90 \%$ & $4.67 \%$ & $2.36 \%$ & $10.06 \%$ & $3.87 \%$ & $7.57 \%$ \\
\hline SR-2 W & $1.27 \%$ & $1.30 \%$ & $2.78 \%$ & $81.36 \%$ & $0.90 \%$ & $3.88 \%$ & $0.26 \%$ & $8.25 \%$ \\
\hline SR-4 E & $1.28 \%$ & $1.31 \%$ & $2.81 \%$ & $1.81 \%$ & $85.66 \%$ & $3.89 \%$ & $0.26 \%$ & $2.97 \%$ \\
\hline US-35 S & $3.07 \%$ & $9.41 \%$ & $6.71 \%$ & $4.36 \%$ & $2.18 \%$ & $66.53 \%$ & $0.63 \%$ & $7.11 \%$ \\
\hline SR-39 S & $0.66 \%$ & $0.69 \%$ & $8.56 \%$ & $0.97 \%$ & $0.49 \%$ & $2.08 \%$ & $84.98 \%$ & $1.56 \%$ \\
\hline SR-2 E & $2.81 \%$ & $2.90 \%$ & $6.16 \%$ & $11.28 \%$ & $2.02 \%$ & $8.67 \%$ & $0.57 \%$ & $65.59 \%$ \\
\hline
\end{tabular}

The scatterplot of predicted versus actual trips, shown in Figure 5.2, indicates a reasonable match between the two. While there are still trips that are overestimated, most of the points are clustered around the line, which represents agreement between estimated and actual trips. This is a significantly better result than that obtained from Modlin's method for the city of Greenfield. 


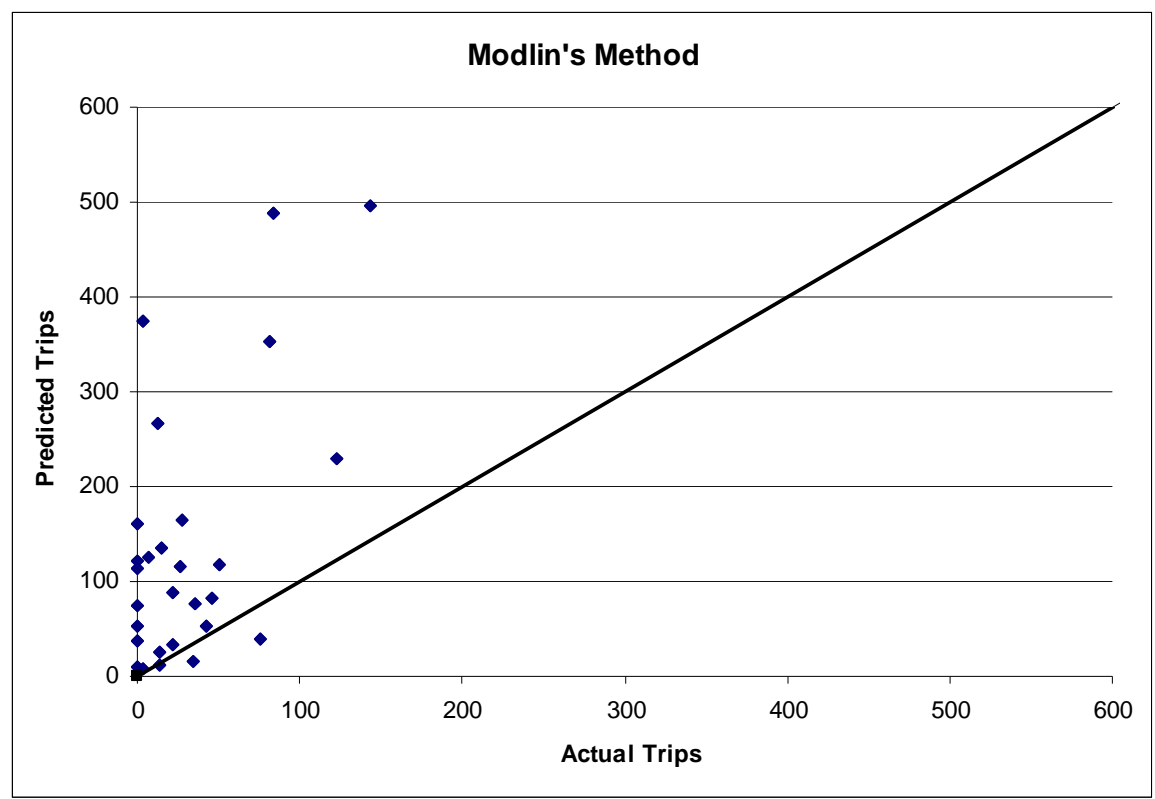

Figure 5.2 - LaPorte Predicted versus Actual Through Trips

The next step in the analysis procedure is the error calculation. As explained in section 3.2.3, the error is estimated by finding the difference between the actual and predicted trips and averaging it for external-external trips and external-internal trips. This calculation yields average errors of 107 and -750 for through and external-internal trips, respectively. A similar error estimation procedure with trip percentages indicates that the through trips are overpredicted on average by 2.5 percent and external-internal trips are underestimated by -17.4 percent.

The second indicator of performance for the method is RMSE. This is calculated using equation 3.5 and indicates the absolute distance between the predicted and actual values. Modlin's method as applied to LaPorte results in RMSE of 7.7 percent.

\subsubsection{Sensitivity Analysis}

The true value of the variable representing the percentage of pickup trucks and vans is unknown. Thus, an average value obtained for all the interstates was used in the analysis. 
This value ( 31 percent), however, varied seasonally between 24 percent and 40 percent and thus sensitivity analysis was performed using the two extreme values to observe how sensitive the through trip percentages are to this variable.

In the case of PPSi being 24 percent, the resulting through trip distribution indicated an increase in the through trips. The trip distribution, as well as percentages of through and external-internal trips, are shown in Tables 5.13 and 5.14.

Table 5.13- LaPorte EE and EI Trip Distribution with PPSi=24\% using Modlin's Method

\begin{tabular}{|l|r|r|r|r|r|r|r|r|}
\hline & $\begin{array}{l}\text { John- } \\
\text { son }\end{array}$ & US35 N & SR39 N & SR2 W & SR4 E & US35 S & SR39 S & SR2 E \\
\hline Johnson & 3414 & 75 & 135 & 101 & 50 & 190 & 17 & 144 \\
\hline US-35 N & 75 & 4094 & 144 & 107 & 53 & 545 & 18 & 153 \\
\hline SR-39 N & 135 & 144 & 2163 & 194 & 97 & 365 & 141 & 277 \\
\hline SR-2 W & 101 & 107 & 194 & 4612 & 72 & 270 & 24 & 532 \\
\hline SR-4 E & 50 & 53 & 97 & 72 & 2427 & 135 & 12 & 103 \\
\hline US-35 S & 190 & 545 & 365 & 270 & 135 & 3327 & 46 & 389 \\
\hline SR-39 S & 17 & 18 & 141 & 24 & 12 & 46 & 1298 & 34 \\
\hline SR-2 E & 144 & 153 & 277 & 532 & 103 & 389 & 34 & 2690 \\
\hline
\end{tabular}

Table 5.14- LaPorte EE and EI Trip Percentages with PPSi=24\% using Modlin's Method

\begin{tabular}{|l|r|r|r|r|r|r|r|r|}
\hline & $\begin{array}{l}\text { John- } \\
\text { Son }\end{array}$ & US35 N & SR39 N & SR2 W & SR4 E & US35 S & SR39 S & SR2 E \\
\hline Johnson & $82.75 \%$ & $1.81 \%$ & $3.27 \%$ & $2.45 \%$ & $1.22 \%$ & $4.60 \%$ & $0.40 \%$ & $3.50 \%$ \\
\hline US-35 N & $1.44 \%$ & $78.91 \%$ & $2.77 \%$ & $2.06 \%$ & $1.03 \%$ & $10.50 \%$ & $0.35 \%$ & $2.95 \%$ \\
\hline SR-39 N & $3.83 \%$ & $4.08 \%$ & $61.54 \%$ & $5.53 \%$ & $2.75 \%$ & $10.39 \%$ & $4.01 \%$ & $7.87 \%$ \\
\hline SR-2 W & $1.71 \%$ & $1.81 \%$ & $3.28 \%$ & $78.00 \%$ & $1.21 \%$ & $4.57 \%$ & $0.41 \%$ & $9.00 \%$ \\
\hline SR-4 E & $1.70 \%$ & $1.81 \%$ & $3.27 \%$ & $2.43 \%$ & $82.30 \%$ & $4.57 \%$ & $0.41 \%$ & $3.49 \%$ \\
\hline US-35 S & $3.60 \%$ & $10.34 \%$ & $6.94 \%$ & $5.13 \%$ & $2.56 \%$ & $63.17 \%$ & $0.87 \%$ & $7.38 \%$ \\
\hline SR-39 S & $1.05 \%$ & $1.13 \%$ & $8.86 \%$ & $1.53 \%$ & $0.76 \%$ & $2.89 \%$ & $81.62 \%$ & $2.16 \%$ \\
\hline SR-2 E & $3.34 \%$ & $3.54 \%$ & $6.40 \%$ & $12.31 \%$ & $2.38 \%$ & $8.99 \%$ & $0.80 \%$ & $62.23 \%$ \\
\hline
\end{tabular}

The average error in the number of trips was evaluated to be 126 for externalexternal trips and -888 for external-internal trips. The corresponding errors in trip percentages were 2.97 percent and -20.8 percent, while the RMSE was determined to be 
8.82 percent. These results are worse than those produced with the assumption of PPSi equal to 31 percent.

Next, Modlin's analysis was performed for the value of PPSi being 40 percent. The results of the through and external-internal trip calculation, as well as percentage distributions are shown in Tables 5.15 and 5.16. The results obtained using the assumption of PPSi equal to 40 percent were better than those obtained with PPSi equal to 31 percent. The error in the through trips decreased to 81 or 1.87 percent and the error in the external-internal trips dropped to -573 or -13.08 percent. The RMSE also decreased to 6.4 percent.

Table 5.15- LaPorte EE and EI Trip Distribution with PPSi=40\% using Modlin's Method

\begin{tabular}{|l|r|r|r|r|r|r|r|r|}
\hline Origins & $\begin{array}{l}\text { John- } \\
\text { son }\end{array}$ & US35 N & SR39 N & SR2 W & SR4 E & US35 S & SR39 S & SR2 E \\
\hline Johnson & 3731 & 30 & 83 & 44 & 23 & 122 & 4 & 90 \\
\hline US-35 N & 30 & 4492 & 84 & 43 & 22 & 427 & 0 & 90 \\
\hline SR-39 N & 83 & 84 & 2433 & 124 & 63 & 345 & 128 & 256 \\
\hline SR-2 W & 44 & 43 & 124 & 5066 & 32 & 177 & 0 & 426 \\
\hline SR-4 E & 24 & 22 & 64 & 32 & 2654 & 88 & 0 & 67 \\
\hline US-35 S & 123 & 429 & 348 & 178 & 88 & 3732 & 0 & 369 \\
\hline SR-39 S & 5 & 0 & 165 & 0 & 0 & 0 & 1420 & 0 \\
\hline SR-2 E & 90 & 90 & 258 & 427 & 67 & 369 & 0 & 3022 \\
\hline
\end{tabular}

Table 5.16- LaPorte EE and EI Trip Percentages with PPSi=40\% using Modlin's Method

\begin{tabular}{|l|r|r|r|r|r|r|r|r|}
\hline Origins & $\begin{array}{l}\text { John- } \\
\text { Son }\end{array}$ & US35 N & SR39 N & SR2 W & SR4 E & US35 S & SR39 S & SR2 E \\
\hline Johnson & $90.43 \%$ & $0.72 \%$ & $2.00 \%$ & $1.05 \%$ & $0.57 \%$ & $2.96 \%$ & $0.10 \%$ & $2.17 \%$ \\
\hline US-35 N & $0.57 \%$ & $86.59 \%$ & $1.63 \%$ & $0.84 \%$ & $0.42 \%$ & $8.22 \%$ & $0.00 \%$ & $1.73 \%$ \\
\hline SR-39 N & $2.35 \%$ & $2.39 \%$ & $69.22 \%$ & $3.52 \%$ & $1.80 \%$ & $9.81 \%$ & $3.64 \%$ & $7.27 \%$ \\
\hline SR-2 W & $0.74 \%$ & $0.73 \%$ & $2.10 \%$ & $85.68 \%$ & $0.54 \%$ & $3.00 \%$ & $0.00 \%$ & $7.20 \%$ \\
\hline SR-4 E & $0.80 \%$ & $0.74 \%$ & $2.16 \%$ & $1.08 \%$ & $89.98 \%$ & $2.98 \%$ & $0.00 \%$ & $2.26 \%$ \\
\hline US-35 S & $2.34 \%$ & $8.14 \%$ & $6.61 \%$ & $3.38 \%$ & $1.67 \%$ & $70.85 \%$ & $0.00 \%$ & $7.01 \%$ \\
\hline SR-39 S & $0.34 \%$ & $0.00 \%$ & $10.36 \%$ & $0.00 \%$ & $0.00 \%$ & $0.00 \%$ & $89.30 \%$ & $0.00 \%$ \\
\hline SR-2 E & $1.70 \%$ & $0.84 \%$ & $4.82 \%$ & $6.27 \%$ & $1.16 \%$ & $8.81 \%$ & $0.00 \%$ & $76.41 \%$ \\
\hline
\end{tabular}




\subsection{Anderson's Method}

\subsection{1 ㅁaa}

The data necessary for trip estimation using Anderson's model is similar to Modlin's. It includes AADT, route continuity factor, and nearby major center indicator. The values of AADT and route continuity factors are shown in Tables 5.4 and 5.7. The nearby major center factor was set to 1 for one of the external stations. The station on US-35 North of the Indiana Toll Road was assumed to lie on the route that leads to a major city (Michigan City).

\subsubsection{Method}

Anderson's method for synthesizing a trip table is described in detail in section 3.2. The trip percentages between each pair of origins and destinations as calculated using equation 3.6 are described in Table 5.17.

Table 5.17- LaPorte Base Trip Percentages using Anderson's Method

\begin{tabular}{|l|r|r|r|r|r|r|r|r|}
\hline & $\begin{array}{l}\text { John- } \\
\text { son }\end{array}$ & US35 N & SR39 N & SR2 W & SR4 E & US35 S & SR39 S & SR2 E \\
\hline Johnson & $52.13 \%$ & $17.79 \%$ & $7.88 \%$ & $5.49 \%$ & $8.44 \%$ & $6.13 \%$ & $9.79 \%$ & $7.07 \%$ \\
\hline US-35 N & $7.27 \%$ & $62.65 \%$ & $7.88 \%$ & $5.49 \%$ & $8.44 \%$ & $15.32 \%$ & $9.79 \%$ & $7.07 \%$ \\
\hline SR-39 N & $7.27 \%$ & $17.79 \%$ & $52.73 \%$ & $5.49 \%$ & $8.44 \%$ & $6.13 \%$ & $18.98 \%$ & $7.07 \%$ \\
\hline SR-2 W & $7.27 \%$ & $17.79 \%$ & $7.88 \%$ & $50.35 \%$ & $8.44 \%$ & $6.13 \%$ & $9.79 \%$ & $16.26 \%$ \\
\hline SR-4 E & $7.27 \%$ & $17.79 \%$ & $7.88 \%$ & $5.49 \%$ & $53.29 \%$ & $6.13 \%$ & $9.79 \%$ & $7.07 \%$ \\
\hline US-35 S & $7.27 \%$ & $26.98 \%$ & $7.88 \%$ & $5.49 \%$ & $8.44 \%$ & $50.99 \%$ & $9.79 \%$ & $7.07 \%$ \\
\hline SR-39 S & $7.27 \%$ & $17.79 \%$ & $17.06 \%$ & $5.49 \%$ & $8.44 \%$ & $6.13 \%$ & $54.65 \%$ & $7.07 \%$ \\
\hline SR-2 E & $7.27 \%$ & $17.79 \%$ & $7.88 \%$ & $14.68 \%$ & $8.44 \%$ & $6.13 \%$ & $9.79 \%$ & $51.93 \%$ \\
\hline
\end{tabular}

In the next step, the trip percentages are used to calculate the number of trips between stations. The trips are then made symmetrical about the intrastation diagonal. (Table 5.18) 
Table 5.18- LaPorte Symmetrical Trip Distribution using Anderson's Method

\begin{tabular}{|l|r|r|r|r|r|r|r|r|}
\hline & $\begin{array}{l}\text { John- } \\
\text { son }\end{array}$ & US35 N & SR39 N & SR2 W & SR4 E & US35 S & SR39 S & SR2 E \\
\hline Johnson & 1875 & 472 & 245 & 272 & 245 & 265 & 223 & 254 \\
\hline US-35 N & 472 & 2623 & 417 & 539 & 405 & 894 & 319 & 458 \\
\hline SR-39 N & 245 & 417 & 1496 & 266 & 221 & 254 & 379 & 238 \\
\hline SR-2 W & 272 & 539 & 266 & 2403 & 272 & 263 & 269 & 644 \\
\hline SR-4 E & 245 & 405 & 221 & 272 & 1370 & 258 & 180 & 238 \\
\hline US-35 S & 265 & 894 & 254 & 263 & 258 & 2168 & 247 & 257 \\
\hline SR-39 S & 223 & 319 & 379 & 269 & 180 & 247 & 701 & 216 \\
\hline SR-2 E & 254 & 458 & 238 & 644 & 238 & 257 & 216 & 1812 \\
\hline
\end{tabular}

\subsubsection{Results}

After balancing the trips shown in Table 5.18 to the actual AADTs, the resulting through trip and external-internal trip distribution is obtained as shown in Table 5.19. The scatterplot showing the relationship between the estimated trips and the observed ones is presented in Figure 5.3. In addition, the percentages of trips from each origin to each destination are detailed in Table 5.20.

Table 5.19- LaPorte Balanced EE and IE Trip Distribution using Anderson's Method

\begin{tabular}{|l|r|r|r|r|r|r|r|r|}
\hline & $\begin{array}{l}\text { John- } \\
\text { son }\end{array}$ & US35 N & SR39 N & SR2 W & SR4 E & US35 S & SR39 S & SR2 E \\
\hline Johnson & 2000 & 414 & 251 & 304 & 233 & 300 & 149 & 475 \\
\hline US-35 N & 414 & 1895 & 352 & 495 & 317 & 832 & 176 & 705 \\
\hline SR-39 N & 251 & 352 & 1476 & 285 & 202 & 277 & 244 & 427 \\
\hline SR-2 W & 304 & 495 & 285 & 2801 & 270 & 311 & 188 & 1258 \\
\hline SR-4 E & 233 & 317 & 202 & 270 & 1162 & 260 & 108 & 397 \\
\hline US-35 S & 300 & 833 & 277 & 311 & 260 & 2601 & 176 & 510 \\
\hline SR-39 S & 149 & 176 & 244 & 188 & 108 & 176 & 295 & 254 \\
\hline SR-2 E & 475 & 705 & 427 & 1258 & 397 & 510 & 254 & 297 \\
\hline
\end{tabular}




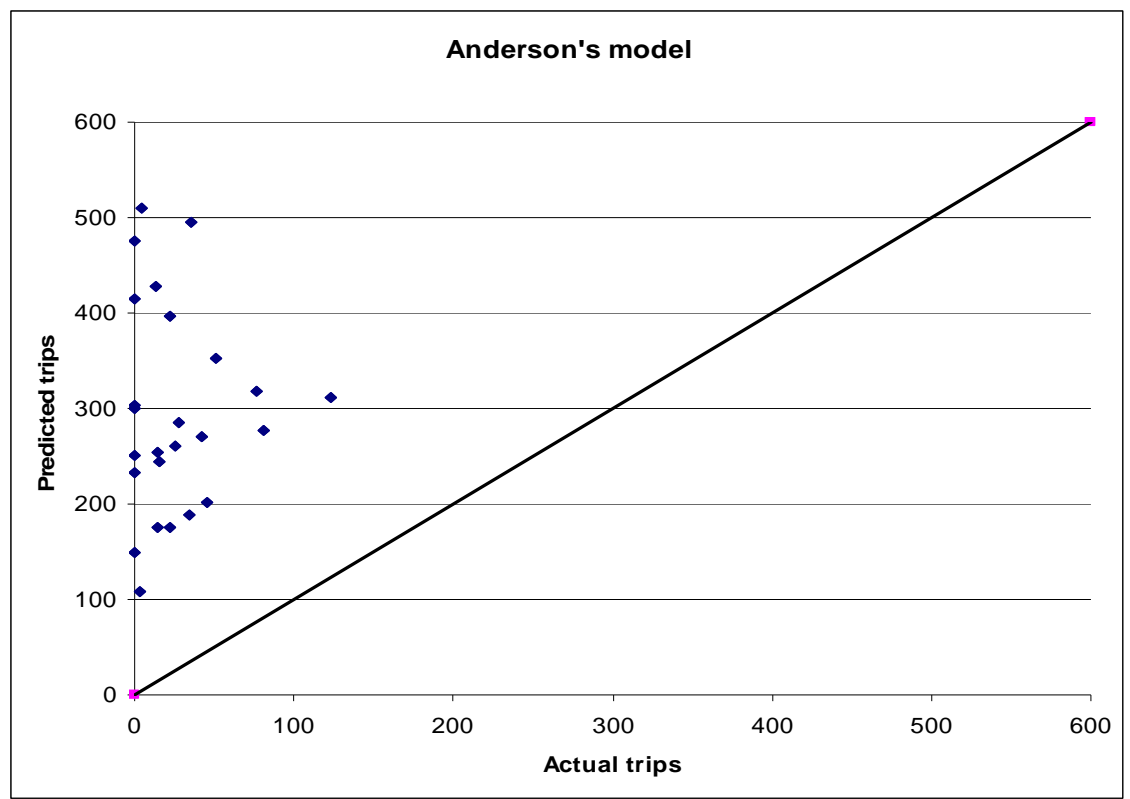

Figure 5.3- LaPorte Predicted versus Actual Through Trips using Anderson's Method

Table 5.20- LaPorte EE and IE Trip Percentages using Anderson's Method

\begin{tabular}{|l|r|r|r|r|r|r|r|r|}
\hline & $\begin{array}{l}\text { John- } \\
\text { son }\end{array}$ & US35 N & SR39 N & SR2 W & SR4 E & US35 S & SR39 S & SR2 E \\
\hline Johnson & $48.48 \%$ & $10.05 \%$ & $6.09 \%$ & $7.36 \%$ & $5.65 \%$ & $7.26 \%$ & $3.62 \%$ & $11.51 \%$ \\
\hline US-35 N & $7.99 \%$ & $36.53 \%$ & $6.79 \%$ & $9.54 \%$ & $6.11 \%$ & $16.05 \%$ & $3.39 \%$ & $13.59 \%$ \\
\hline SR-39 N & $7.14 \%$ & $10.02 \%$ & $42.00 \%$ & $8.11 \%$ & $5.75 \%$ & $7.88 \%$ & $6.94 \%$ & $12.16 \%$ \\
\hline SR-2 W & $5.13 \%$ & $8.37 \%$ & $4.82 \%$ & $47.37 \%$ & $4.57 \%$ & $5.26 \%$ & $3.18 \%$ & $21.28 \%$ \\
\hline SR-4 E & $7.91 \%$ & $10.76 \%$ & $6.85 \%$ & $9.17 \%$ & $39.39 \%$ & $8.83 \%$ & $3.65 \%$ & $13.45 \%$ \\
\hline US-35 S & $5.69 \%$ & $15.81 \%$ & $5.26 \%$ & $5.91 \%$ & $4.94 \%$ & $49.37 \%$ & $3.34 \%$ & $9.68 \%$ \\
\hline SR-39 S & $9.39 \%$ & $11.07 \%$ & $15.35 \%$ & $11.85 \%$ & $6.76 \%$ & $11.06 \%$ & $18.57 \%$ & $15.96 \%$ \\
\hline SR-2 E & $10.98 \%$ & $16.31 \%$ & $9.88 \%$ & $29.11 \%$ & $9.18 \%$ & $11.80 \%$ & $5.87 \%$ & $6.87 \%$ \\
\hline
\end{tabular}

The comparison of the estimated trips with the observed trips indicates a large discrepancy between the two. The differences between the predicted percentages of trips and the actual ones are shown in Table 5.21. The average errors in the percentage of estimated trips are 8.36 percent for through trips and -58.5 percent for external-internal trips. The same errors in terms of trip numbers are 232 and -2326 for external-external and external-internal trips, respectively. The RMSE for Anderson's analysis is 19.93 percent, which is more than 3 times as large as the RMSE in Modlin's method. 
Table 5.21- LaPorte Percent Error between Actual and Predicted Trips using Anderson's Method

\begin{tabular}{|l|r|r|r|r|r|r|r|r|}
\hline & $\begin{array}{l}\text { John- } \\
\text { Son }\end{array}$ & US35 N & SR39 N & SR2 W & SR4 E & US35 S & SR39 S & SR2 E \\
\hline Johnson & $-51.5 \%$ & $10.05 \%$ & $6.09 \%$ & $7.36 \%$ & $5.65 \%$ & $7.26 \%$ & $3.62 \%$ & $11.51 \%$ \\
\hline US-35 N & $7.99 \%$ & $-57.2 \%$ & $5.81 \%$ & $8.85 \%$ & $4.65 \%$ & $13.29 \%$ & $3.12 \%$ & $13.46 \%$ \\
\hline SR-39 N & $7.14 \%$ & $8.57 \%$ & $-51.4 \%$ & $7.32 \%$ & $4.44 \%$ & $5.57 \%$ & $6.52 \%$ & $11.79 \%$ \\
\hline SR-2 W & $5.13 \%$ & $7.76 \%$ & $4.35 \%$ & $-46.8 \%$ & $3.86 \%$ & $3.18 \%$ & $2.61 \%$ & $19.86 \%$ \\
\hline SR-4 E & $7.91 \%$ & $8.18 \%$ & $5.29 \%$ & $7.74 \%$ & $-53.3 \%$ & $7.95 \%$ & $3.54 \%$ & $12.71 \%$ \\
\hline US-35 S & $5.69 \%$ & $13.10 \%$ & $3.73 \%$ & $3.58 \%$ & $4.45 \%$ & $-43.1 \%$ & $2.92 \%$ & $9.61 \%$ \\
\hline SR-39 S & $9.39 \%$ & $10.19 \%$ & $14.41 \%$ & $9.71 \%$ & $6.57 \%$ & $9.68 \%$ & $-75.0 \%$ & $15.08 \%$ \\
\hline SR-2 E & $10.98 \%$ & $16.15 \%$ & $9.58 \%$ & $27.17 \%$ & $8.67 \%$ & $11.71 \%$ & $5.55 \%$ & $-89.8 \%$ \\
\hline $\begin{array}{l}\text { Average } \\
\text { EE error }\end{array}$ & $8.36 \%$ & & & & & & & \\
\hline $\begin{array}{l}\text { Average } \\
\text { El error }\end{array}$ & $-58.5 \%$ & & & & & & & \\
\hline
\end{tabular}

\section{$5.3 \underline{\text { Subarea Analysis }}$}

\subsubsection{Data}

Subarea analysis uses the data from the Indiana Statewide Demand Model to evaluate the flows through the delineated subarea and to estimate the origin destination matrix.

\subsubsection{Method}

An in-depth description of how the analysis is performed in TransCAD is given in section 3.4. The analysis essentially consists of delineating the community of interest (city of LaPorte in this case) and running Subarea Analysis using the total OD statewide matrix.

\subsubsection{Results}

The through trip distribution obtained using subarea analysis is made symmetrical and balanced to the AADT using the biproportional method (Table 5.22). The through trip percentages are also calculated for easier interpretation of the results (Table 5.23). 
The scatterplot, presented in Figure 5.4, also allows a visual inspection of the discrepancies between the predicted and the actual trips. The resulting errors in the average number of through trips and external-internal trips are 50 and -352 , with the corresponding errors in the average percentage of vehicles being 1.24 percent and -8.68 percent. The RMSE was determined to be 4.9 percent, which is the lowest value out of the three methods applied up to this point.

Table 5.22- LaPorte Base EE and EI Trip Distribution using Subarea Analysis

\begin{tabular}{|l|r|r|r|r|r|r|r|r|}
\hline & $\begin{array}{l}\text { John- } \\
\text { Son }\end{array}$ & US35 N & SR39 N & SR2 W & SR4 E & US35 S & SR39 S & SR2 E \\
\hline Johnson & 3593 & 5 & 74 & 0 & 152 & 204 & 0 & 97 \\
\hline US-35 N & 5 & 4868 & 0 & 0 & 154 & 154 & 8 & 0 \\
\hline SR-39 N & 73 & 0 & 3383 & 0 & 15 & 31 & 12 & 0 \\
\hline SR-2 W & 0 & 0 & 0 & 5574 & 104 & 67 & 52 & 118 \\
\hline SR-4 E & 153 & 154 & 15 & 103 & 2380 & 55 & 6 & 84 \\
\hline US-35 S & 205 & 154 & 32 & 66 & 55 & 4361 & 0 & 396 \\
\hline SR-39 S & 0 & 8 & 12 & 52 & 6 & 0 & 1438 & 74 \\
\hline SR-2 E & 97 & 0 & 0 & 117 & 84 & 396 & 74 & 3555 \\
\hline
\end{tabular}

Table 5.23- LaPorte Balanced EE and EI Trip Percentages using Subarea Analysis

\begin{tabular}{|l|r|r|r|r|r|r|r|r|}
\hline & $\begin{array}{l}\text { John- } \\
\text { Son }\end{array}$ & US35 N & SR39 N & SR2 W & SR4 E & US35 S & SR39 S & SR2 E \\
\hline Johnson & $87.10 \%$ & $0.12 \%$ & $1.79 \%$ & $0.00 \%$ & $3.69 \%$ & $4.95 \%$ & $0.00 \%$ & $2.35 \%$ \\
\hline US-35 N & $0.10 \%$ & $93.82 \%$ & $0.00 \%$ & $0.00 \%$ & $2.96 \%$ & $2.97 \%$ & $0.15 \%$ & $0.00 \%$ \\
\hline SR-39 N & $2.08 \%$ & $0.00 \%$ & $96.28 \%$ & $0.00 \%$ & $0.42 \%$ & $0.88 \%$ & $0.34 \%$ & $0.00 \%$ \\
\hline SR-2 W & $0.00 \%$ & $0.00 \%$ & $0.00 \%$ & $94.24 \%$ & $1.76 \%$ & $1.13 \%$ & $0.88 \%$ & $1.99 \%$ \\
\hline SR-4 E & $5.18 \%$ & $5.21 \%$ & $0.51 \%$ & $3.51 \%$ & $80.71 \%$ & $1.85 \%$ & $0.20 \%$ & $2.83 \%$ \\
\hline US-35 S & $3.89 \%$ & $2.92 \%$ & $0.60 \%$ & $1.26 \%$ & $1.04 \%$ & $82.79 \%$ & $0.00 \%$ & $7.51 \%$ \\
\hline SR-39 S & $0.00 \%$ & $0.49 \%$ & $0.76 \%$ & $3.27 \%$ & $0.37 \%$ & $0.00 \%$ & $90.46 \%$ & $4.64 \%$ \\
\hline SR-2 E & $2.25 \%$ & $0.00 \%$ & $0.00 \%$ & $2.72 \%$ & $1.93 \%$ & $9.16 \%$ & $1.71 \%$ & $82.24 \%$ \\
\hline
\end{tabular}




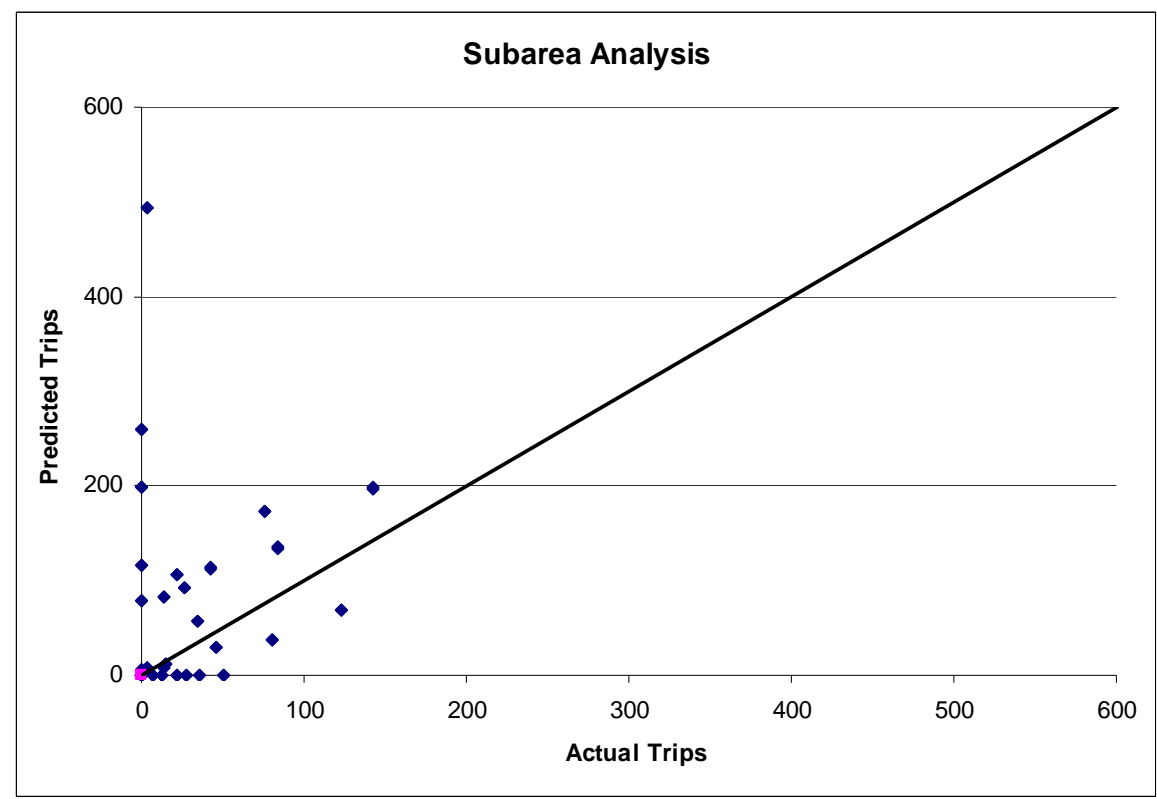

Figure 5.4- LaPorte Predicted versus Actual Trips using Subarea Analysis

\subsection{Logit Model}

\subsubsection{Data}

The data necessary to estimate the through trips as well as external-internal trips for LaPorte included relative AADT at each station as compared to all the other stations as and route continuity factors for each pair of stations. The AADT and route continuity factors were already determined for all the stations in section 5.1.1. The relative AADT was determined by dividing the AADT at the particular station by the AADT at all stations. The values of all the parameters used in calculating trips are presented in Appendix D.

\subsubsection{Method}

The calculation of through trips using the logit model is simple and similar to the calculation using Anderson's method. First, the through trip and the external-internal trip 
percentages are calculated using equation 4.6. Then, these percentages are multiplied by AADT to yield the number of trips between each pair of stations. Lastly, the trips are made symmetrical and adjusted to match the AADT at each external station using the biproportional balancing method.

\subsubsection{Results}

The resulting through (EE) and external-internal (EI) trips between each pair of stations are shown in Table 5.24. The corresponding trip percentages are described in Table 5.25. In addition, the scatter plot of the predicted versus actual trips is illustrated in Figure 5.5.

Table 5.24- LaPorte EE and EI Trip Distribution using Logit Model

\begin{tabular}{|l|r|r|r|r|r|r|r|r|}
\hline & $\begin{array}{l}\text { John- } \\
\text { son }\end{array}$ & US35 N & SR39 N & SR2 W & SR4 E & US35 S & SR39 S & SR2 E \\
\hline Johnson & 3248 & 150 & 112 & 171 & 100 & 153 & 64 & 128 \\
\hline US-35 N & 150 & 3795 & 130 & 198 & 116 & 575 & 75 & 149 \\
\hline SR-39 N & 112 & 130 & 2621 & 148 & 86 & 132 & 176 & 110 \\
\hline SR-2 W & 171 & 198 & 148 & 4430 & 132 & 201 & 85 & 548 \\
\hline SR-4 E & 100 & 116 & 86 & 132 & 2250 & 118 & 48 & 98 \\
\hline US-35 S & 153 & 575 & 132 & 201 & 118 & 3864 & 76 & 149 \\
\hline SR-39 S & 64 & 75 & 176 & 85 & 48 & 76 & 1003 & 63 \\
\hline SR-2 E & 128 & 149 & 110 & 548 & 98 & 149 & 63 & 3079 \\
\hline
\end{tabular}

Table 5.25- LaPorte EE and EI Trip Percentages using Logit Model

\begin{tabular}{|l|r|r|r|r|r|r|r|r|}
\hline & $\begin{array}{l}\text { John- } \\
\text { son }\end{array}$ & US35 N & SR39 N & SR2 W & SR4 E & US35 S & SR39 S & SR2 E \\
\hline Johnson & $78.72 \%$ & $3.65 \%$ & $2.71 \%$ & $4.14 \%$ & $2.42 \%$ & $3.70 \%$ & $1.56 \%$ & $3.10 \%$ \\
\hline US-35 N & $2.90 \%$ & $73.14 \%$ & $2.51 \%$ & $3.82 \%$ & $2.24 \%$ & $11.09 \%$ & $1.44 \%$ & $2.86 \%$ \\
\hline SR-39 N & $3.18 \%$ & $3.70 \%$ & $74.57 \%$ & $4.21 \%$ & $2.44 \%$ & $3.75 \%$ & $5.01 \%$ & $3.14 \%$ \\
\hline SR-2 W & $2.89 \%$ & $3.35 \%$ & $2.50 \%$ & $74.91 \%$ & $2.23 \%$ & $3.40 \%$ & $1.44 \%$ & $9.26 \%$ \\
\hline SR-4 E & $3.39 \%$ & $3.94 \%$ & $2.91 \%$ & $4.48 \%$ & $76.31 \%$ & $4.00 \%$ & $1.63 \%$ & $3.34 \%$ \\
\hline US-35 S & $2.90 \%$ & $10.92 \%$ & $2.50 \%$ & $3.82 \%$ & $2.24 \%$ & $73.36 \%$ & $1.44 \%$ & $2.82 \%$ \\
\hline SR-39 S & $4.04 \%$ & $4.70 \%$ & $11.08 \%$ & $5.37 \%$ & $3.02 \%$ & $4.77 \%$ & $63.08 \%$ & $3.94 \%$ \\
\hline SR-2 E & $2.96 \%$ & $3.44 \%$ & $2.55 \%$ & $12.67 \%$ & $2.28 \%$ & $3.44 \%$ & $1.45 \%$ & $71.22 \%$ \\
\hline
\end{tabular}




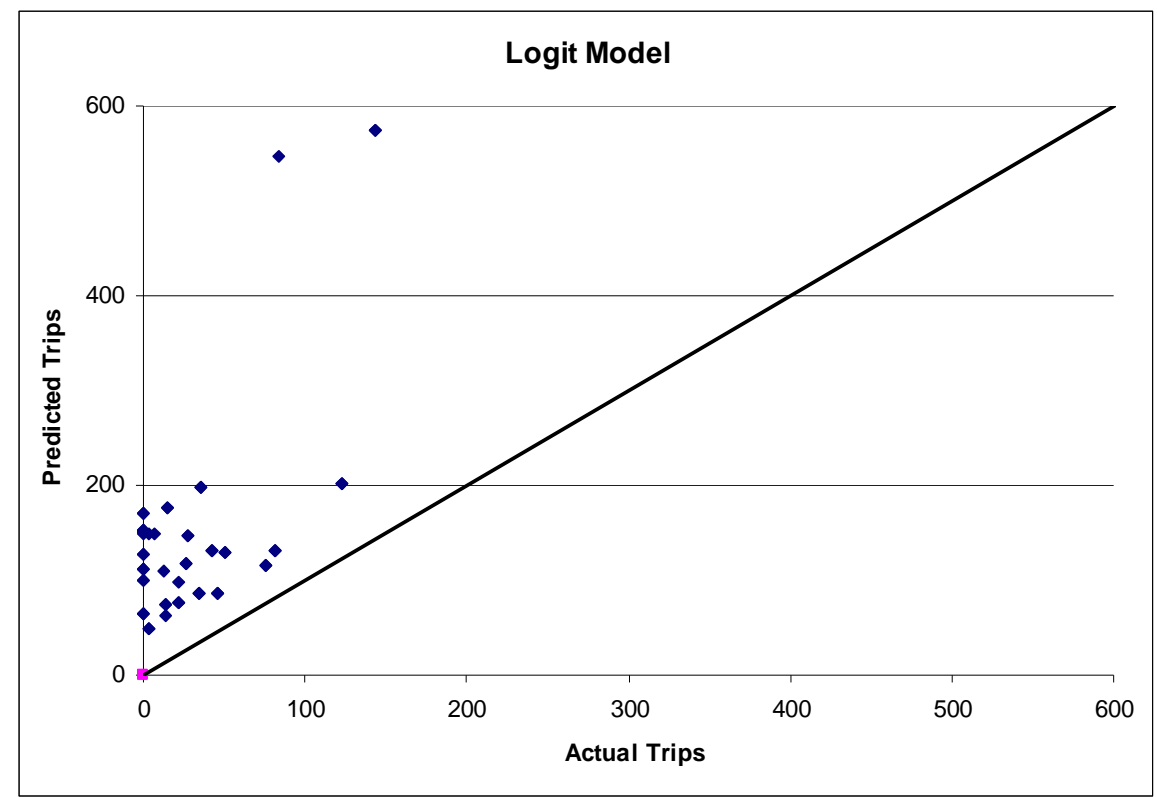

Figure 5.5- LaPorte Predicted versus Actual Trips using Logit Model

The error calculation for logit model is completed as described in previous sections. The average difference between the estimated and actual through trips is 122 and the same difference for external internal trips is $\mathbf{- 8 5 5}$. The average errors in the percentages of through and external- internal trips are 3.0 percent and -21 percent, respectively. The root mean square error for the logit model analysis is 8.46 percent.

\subsection{Summary}

Estimation of through trips for the city of LaPorte using 4 different methods yielded different results. The errors for the different methods are shown in Table 5.26. Subarea analysis proved to produce the best results, similar to the city of Greenfield, while Anderson's method generated the worst trip table. The trip tables synthesized using Modlin's method and logit model were similar, with Modlin's through trips predicted slightly more accurately. However, the difference between the RMSE of the two methods is small, and because the logit model is easier to apply and is statistically justifiable, it may be preferable. 
Table 5.26- LaPorte Errors Arising from Different OD Estimation Methods

\begin{tabular}{|l|r|r|r|r|r|}
\hline & \multicolumn{1}{|l|}{ EE Trips } & \multicolumn{1}{|l|}{ IE Trips } & EE Trip \% & IE Trip \% & \multicolumn{1}{l|}{ RMSE } \\
\hline Modlin's Method & 107 & -750 & $2.49 \%$ & $-17.4 \%$ & $7.70 \%$ \\
\hline Anderson's Method & 288 & -2017 & $7.35 \%$ & $-51.45 \%$ & $19.93 \%$ \\
\hline Subarea Analysis & 35 & -248 & $1.24 \%$ & $-8.68 \%$ & $4.90 \%$ \\
\hline Logit Model & 122 & -855 & $3.00 \%$ & $-21.0 \%$ & $8.46 \%$ \\
\hline
\end{tabular}




\section{CHAPTER 6. CONCLUSIONS}

\subsection{Overview}

Evaluation of the models commonly used to estimate through trips based on two cities in Indiana yielded some interesting results. Modlin's method, which is used in many states, worked reasonably well for the city of LaPorte, but it failed to accurately predict trips for the city of Greenfield. One of the reasons for the subpar performance may be the age of the method. The equations used by the method were calibrated in 1975. Since then, the impact of some factors may have changed, while others may have become obsolete. For example, the variable corresponding to the percentage of pickup trucks and vans may not be meaningful in today's analysis, because these vehicles are used interchangeably with sedans. It is also unclear how sport utility vehicles would affect this parameter.

When Anderson's method was evaluated, it produced inadequate results for cities of Greenfield and LaPorte in Indiana, with RMSE of 18.7 percent and 20 percent, respectively. It appears that this model cannot accurately estimate through trips for either small (Greenfield) or medium-sized (LaPorte) cities in Indiana. The through trips for both communities were significantly overestimated. This problem may arise because of Anderson's use of a relatively homogenous set of cities to calibrate his model.

In addition to sometimes poor performance, both Modlin's and Anderson's methods suffer from lack of statistical justification and vague definitions of the key variables. Linear regression may not be the best way to model choice-based decisions. Linear regression's simplicity is very attractive, but that alone is insufficient reason to use it. The second problem with Modlin's and Anderson's methods is the absence of parameter explanations, which results in conflicting model coefficients when it comes to AADT. Modlin's method indicates that higher AADT increases the percentage of through trips 
destined to a station, while Anderson's model yields the opposite result. Lastly, both models fail to provide guidance on the use of the route continuity factor, leaving it to the planner's discretion. Anderson's model also omits guidance on how to define a "nearby major center".

The third existing method used is subarea analysis. Unlike Modlin's and Anderson's methods, it relies on a macro simulation of the entire state network, from which the subarea is then extracted. From the application of subarea analysis for the cities of Greenfield and LaPorte, it is evident that it produces the best results. This is not unexpected, because actual traffic patterns can be taken into account within this framework. One concern that frequently exists with this method is whether it is able to adequately extract the traffic patterns in a small urban area from the state framework. While subarea analysis performed on a statewide model may not accurately predict internal traffic patterns in small communities, traffic flows on major routes are usually accurate because they are calibrated to the AADT. Thus, subarea analysis remains the most effective method of predicting through trips and external-internal trips. One drawback of this method is the high cost of the software license as well as the need for personnel who are trained to use TransCAD to perform the analysis. In cases where the network and zone structure is clearly too coarse to realize the advantages of subarea analysis, the skilled user may consider investing effort in refining those structures.

The last method for estimating through trips that was proposed and evaluated in this study is the logit model.

$$
\begin{aligned}
& \mathrm{U}(\mathrm{EI})=3.78 \\
& \mathrm{U}(\mathrm{EE})=\left(1.177 * \mathrm{RTECON}_{\mathrm{ij}}\right)+\left(4.448 * \frac{\text { AADT }_{\mathrm{j}}}{\sum \text { AADT }_{\mathrm{j}}}\right)
\end{aligned}
$$

Based on results obtained from testing all three methods on the cities of Greenfield (Table 4.9) and LaPorte (Table 5.26), it is evident that, in most cases, this model performs better than Modlin's and Anderson's methods. At the same time, it remedies some of the flaws of these methods by using a multinomial logit model to represent the 
choice-based decision and providing guidance in selecting the appropriate route continuity factor. Another advantage of using the logit model is the simplicity of application; it only requires AADT information and route continuity. However, as with other models, it has a drawback. The logit model is most effective applied to cities between 5,000 and 30,000 people (because it was calibrated for cities of this size), while Modlin's method is intended for "small urban areas, particularly those with populations of 50,000 or less." (Martin and McGuckin, 1998) Normally, subarea analysis is the best way to estimate through-trip tables for small urban areas, because it operates in the context of the statewide network model. In case when the statewide model is not available to an analyst, the logit model is a good substitute. Called "Through Route Estimation By Logit" (TREBL), the logit model can be implemented using a spreadsheet.

\subsection{Implementation}

The logit model has been implemented in an Excel spreadsheet. The planner would be required to enter the AADT data as well as the route continuity matrix, containing 0 or 1 entries based on the network geometry and the planner's knowledge of the traffic patterns. (See Table 3.4 for an example of route continuity matrix for Greenfield.) Then, the output matrix with the number of trips as well as the relative percentage of trips between each pair of cordon stations will be displayed in the output sheet.

\subsection{Future Research}

As discussed previously, the proposed model was estimated using results produced by the subarea procedure. It has been shown that, while the subarea procedure produces good estimates of external-external and external-internal trips, it also contains error. Because the logit model was based on subarea analyses, the logit model would greatly benefit if it was calibrated using data obtained from a set of reliable origin-destination vehicle license plate surveys. A larger sample size would also benefit the model, because 76 observations may not provide sufficient information and some important parameters 
may have been omitted. Furthermore, to make the model transferable to cities in states other than Indiana, it would probably be necessary to recalibrate the model to the cities in a different state. 


\section{LIST OF REFERENCES}

Anderson, M., Abdullah, Y., Gholston, S., Jones, S. (2006). Development of a Methodology to Predict Through-Trip Rates for Small Communities. Journal of Urban Planning and Development.

Bernardin-Lochmueller and Associates Inc. (2007). Economic Development Corridor Feasibility Study. INDOT.

Horowitz, A. and Patel, M. (1999). Through Trip Tables for Small Urban Area: A Method for Quick Response Travel Forecasting. Transportation Research Record 1685, Transportation Research Board.

Martin, W. A. and McGuckin, N. A. (1998). Travel Estimation Techniques for Urban Planning. National Cooperative Highway Research Program, Rep. 365, Transportation Research Board.

Meyer, M. and Miller, E. Urban Transportation Planning: A Decision-Oriented Approach. (2001). McGraw-Hill, New York, 2nd edition, 2001.

Paul I. Cripe Inc. (2004). Part B of the Environmental Assessment of the SR-9 corridor. INDOT.

Transformation Systems Inc. (2001). Jasper, Indiana Origin-Destination Study Video Survey Proposal. INDOT.

U.S. Census Bureau. (2000). Estimated Daytime Population and EmploymentResidence Ratios. Retrieved September 25, 2007. http://www.census.gov/population/www/socdemo/daytime/daytimepop.html 
Washington, S., Karlaftis, M., Mannering, F. (2003) Statistical and econometric methods for transportation data analysis, Chapman \& Hall/CRC, Boca Raton, FL. 


\section{$\underline{\text { Appendix A }}$}

Maps of Cities Used to Calibrate the Logit Model are presented in this section

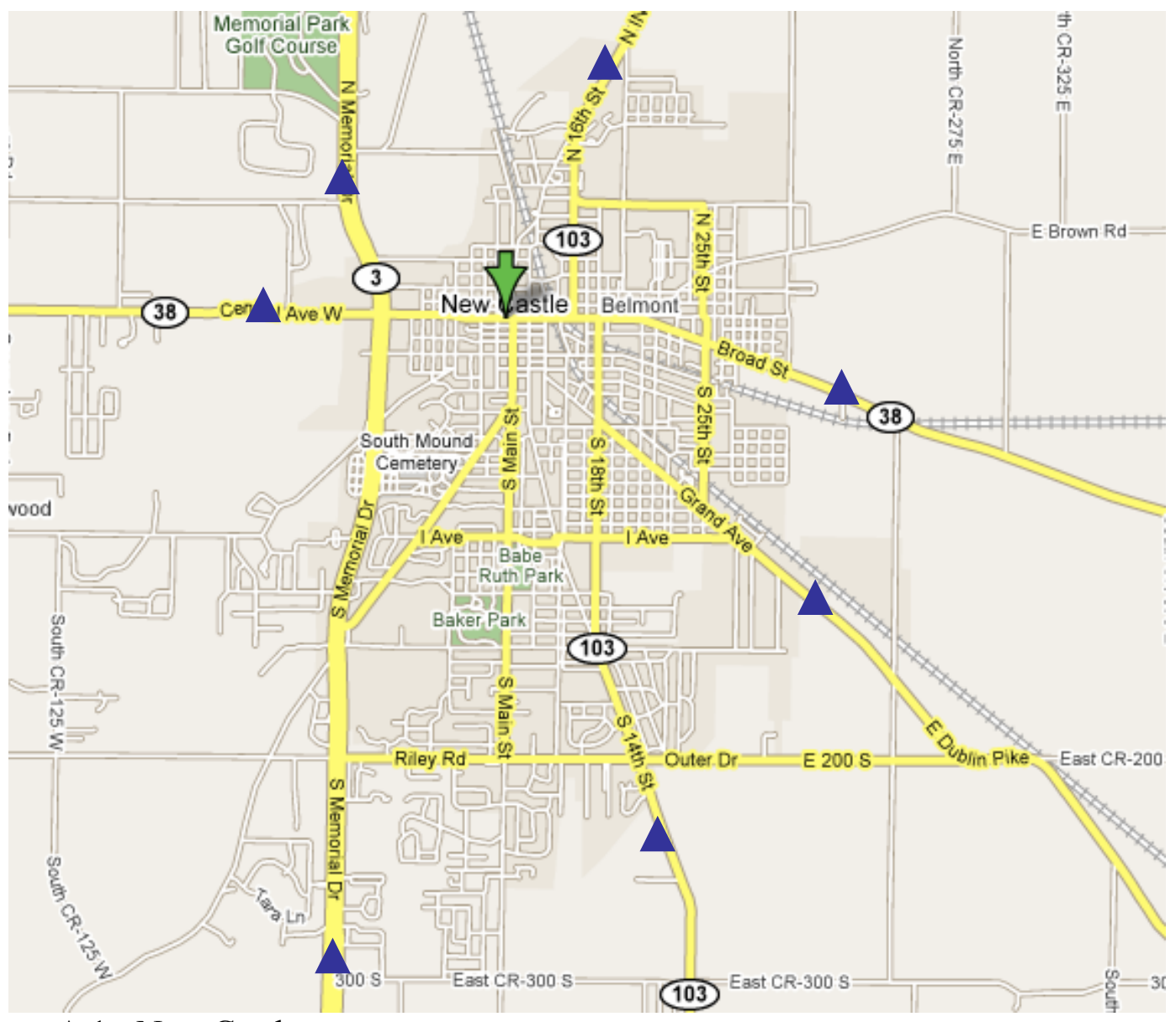

Figure A.1- New Castle 


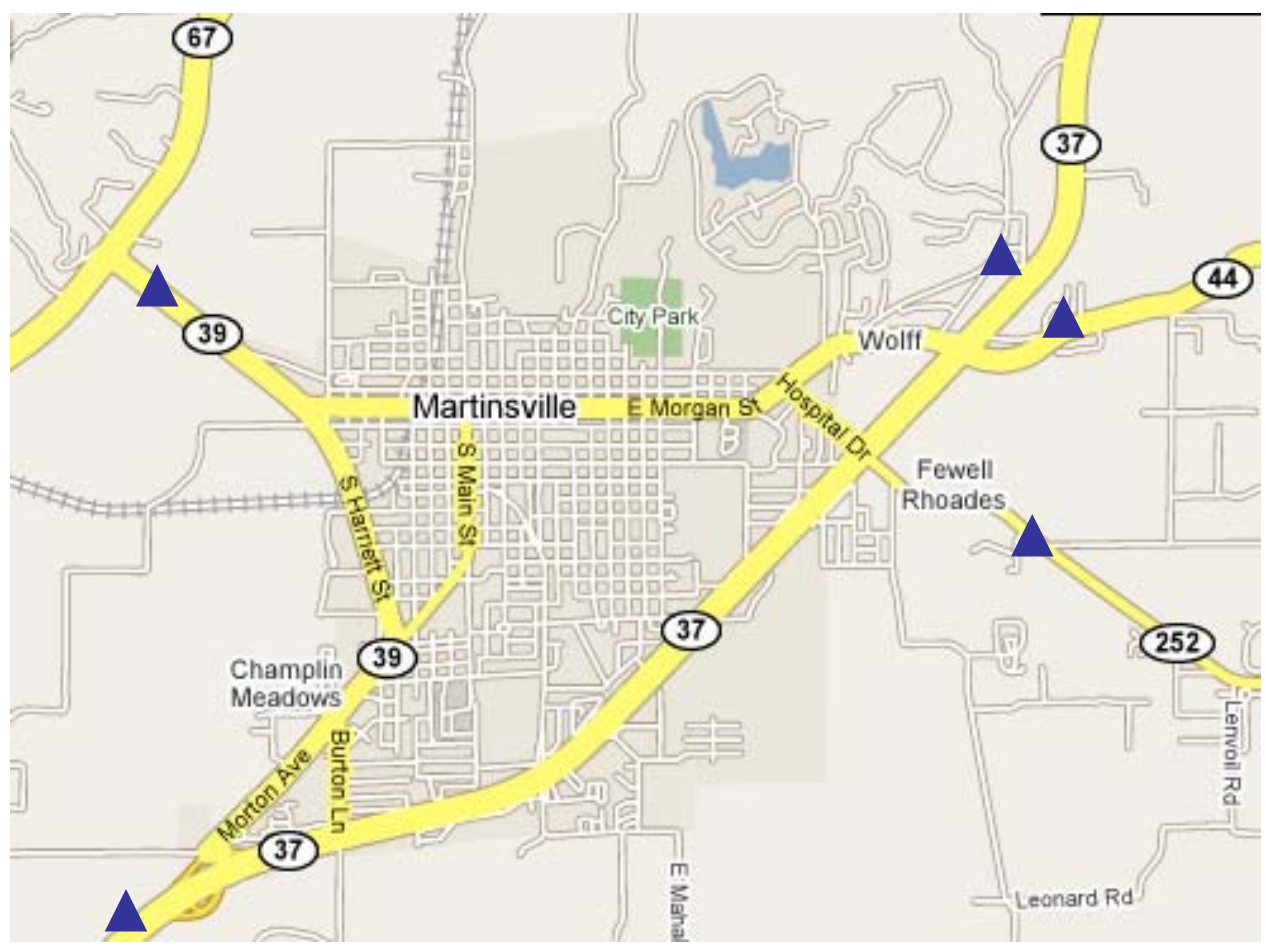

Figure A.2- Martinsville

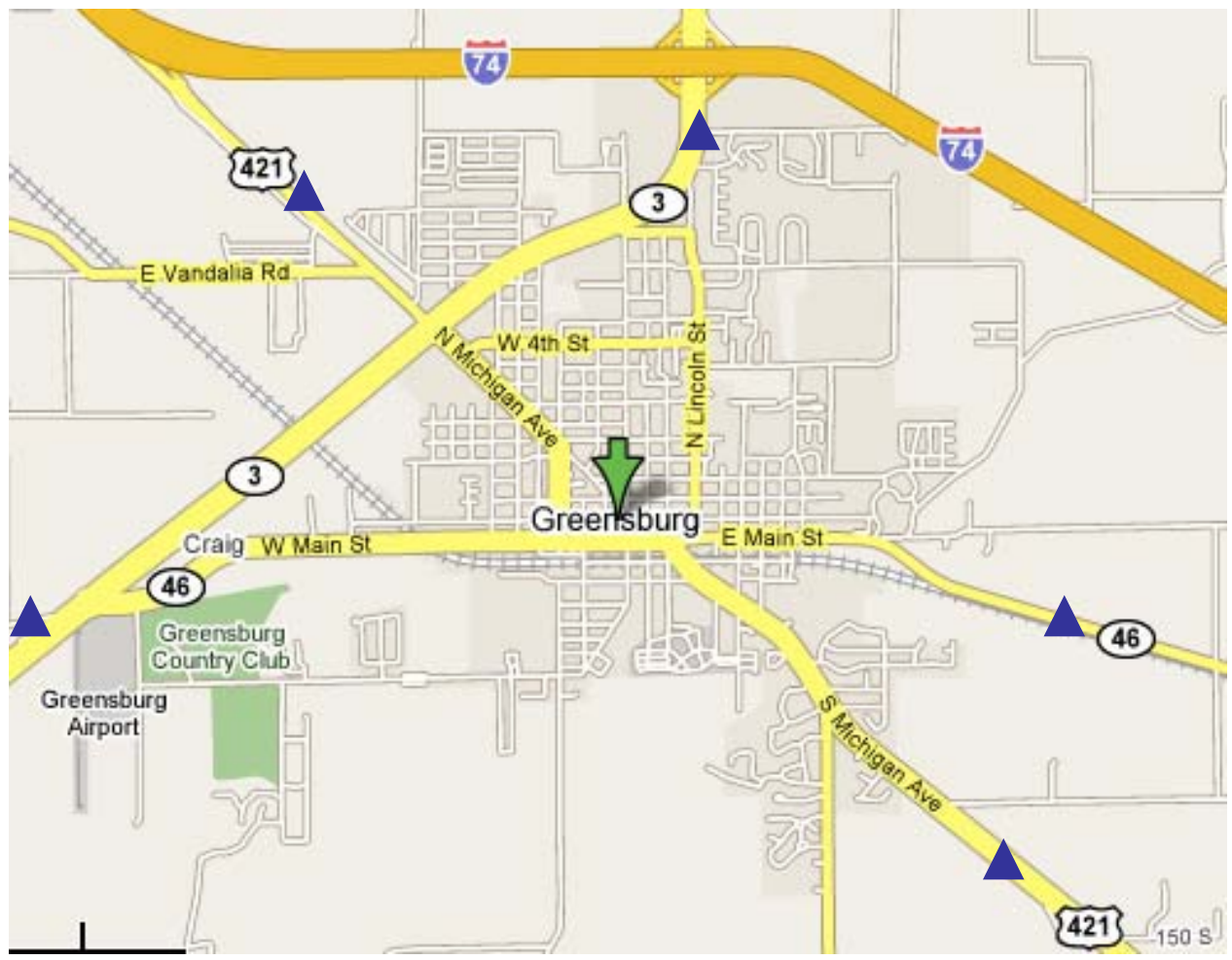

Figure $\overline{\text { A.3-Greensburg }}$ 


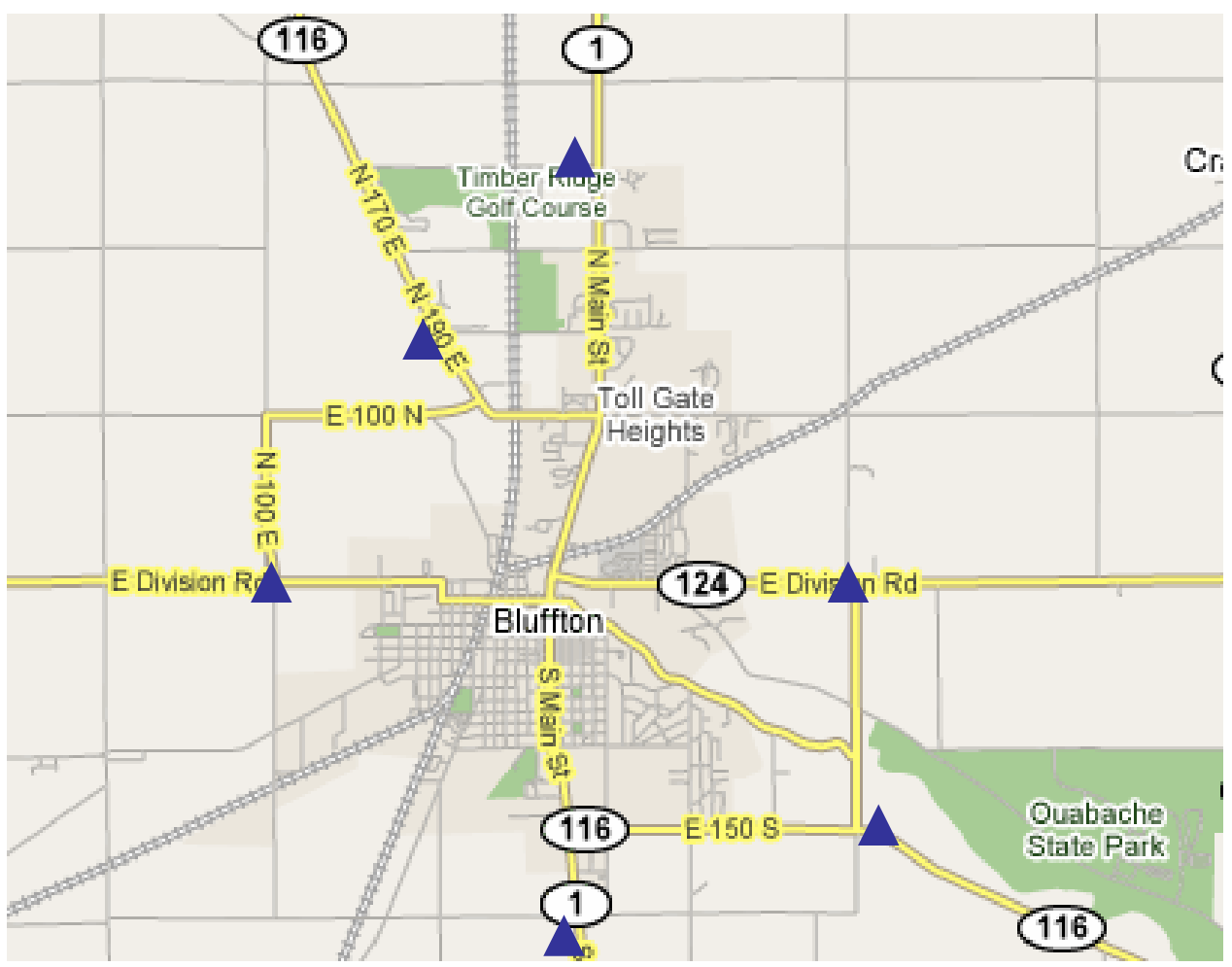

Figure A.4- Bluffton

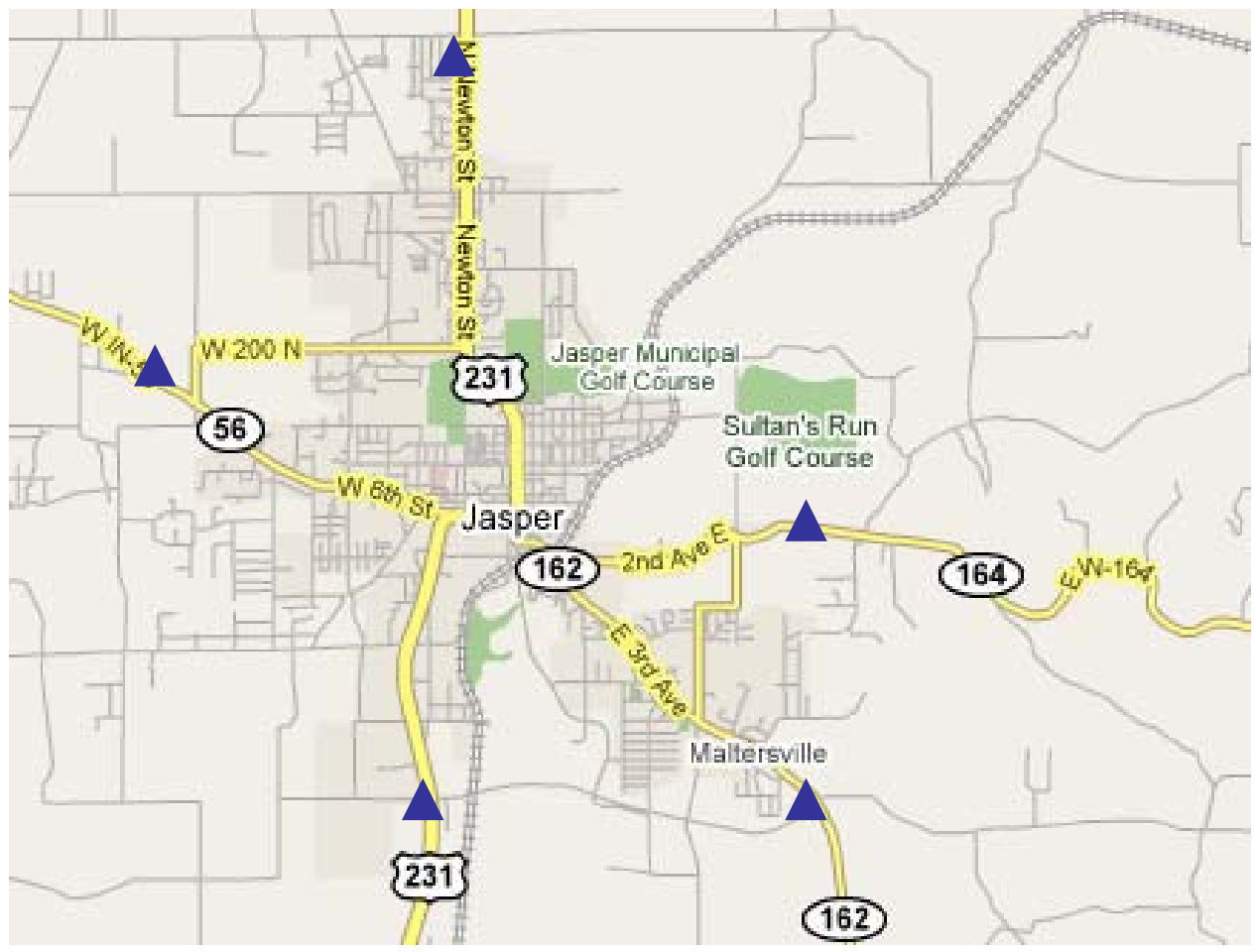

Figure A.5- Jasper 


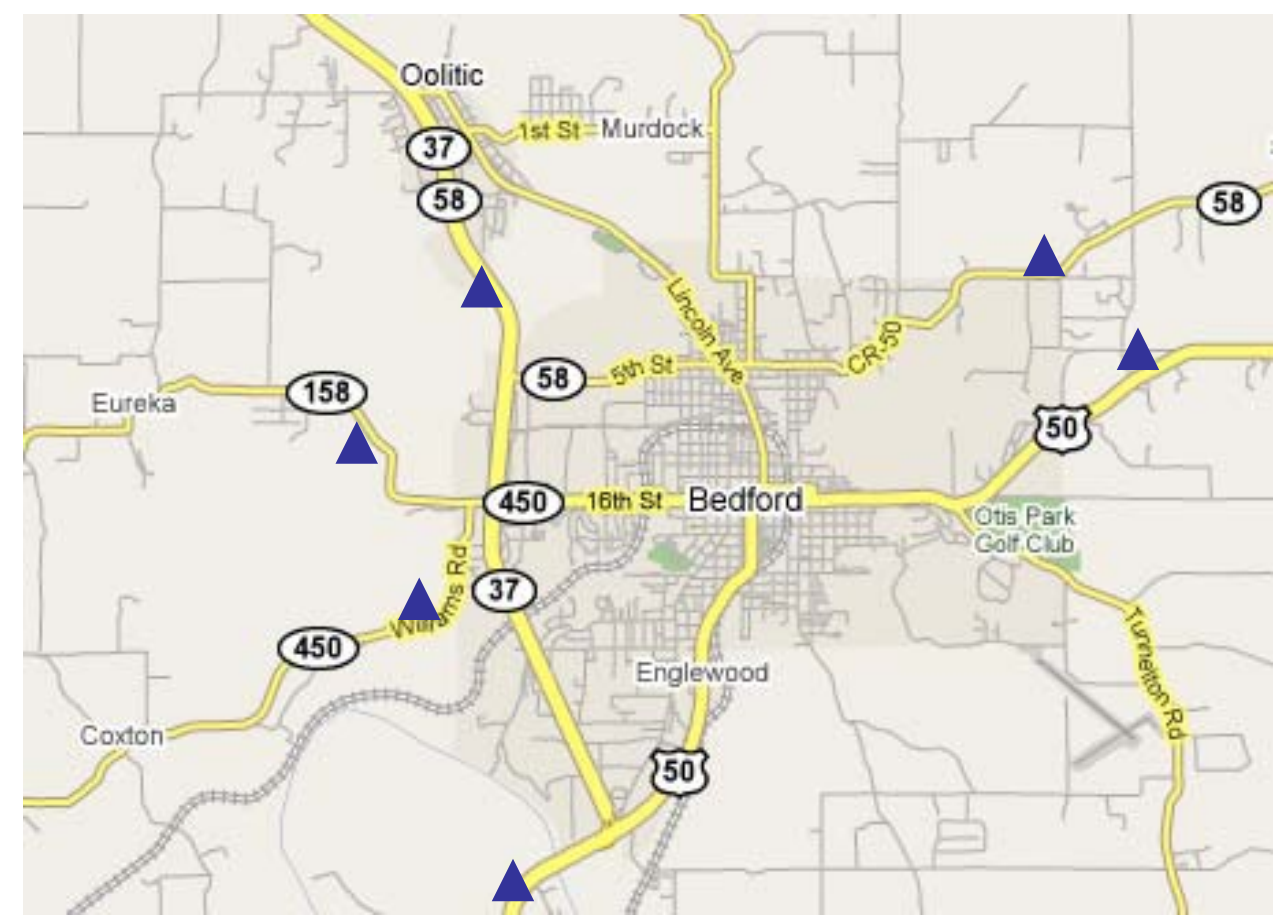

Figure A.6- Bedford

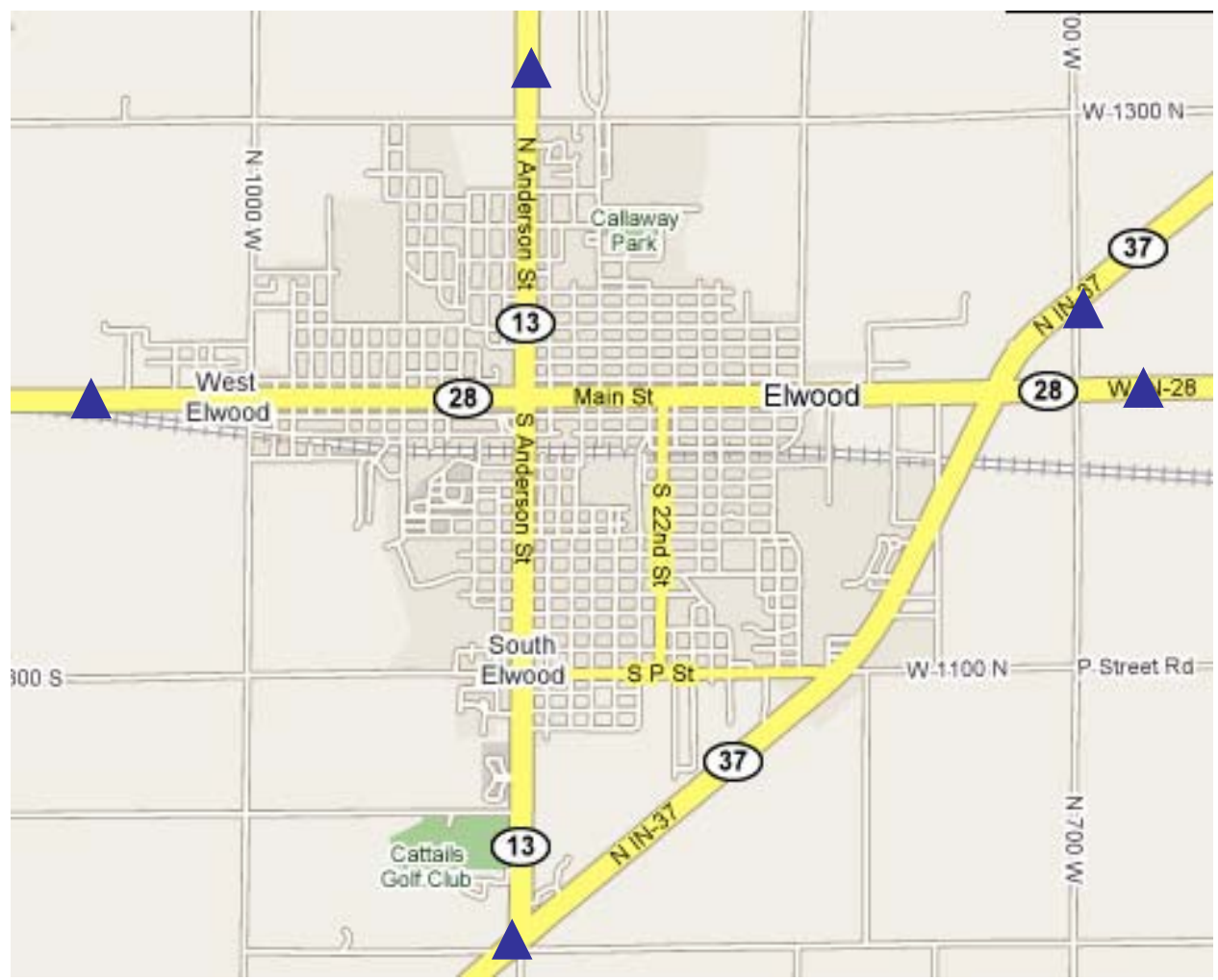

Figure A.7- Elwood 


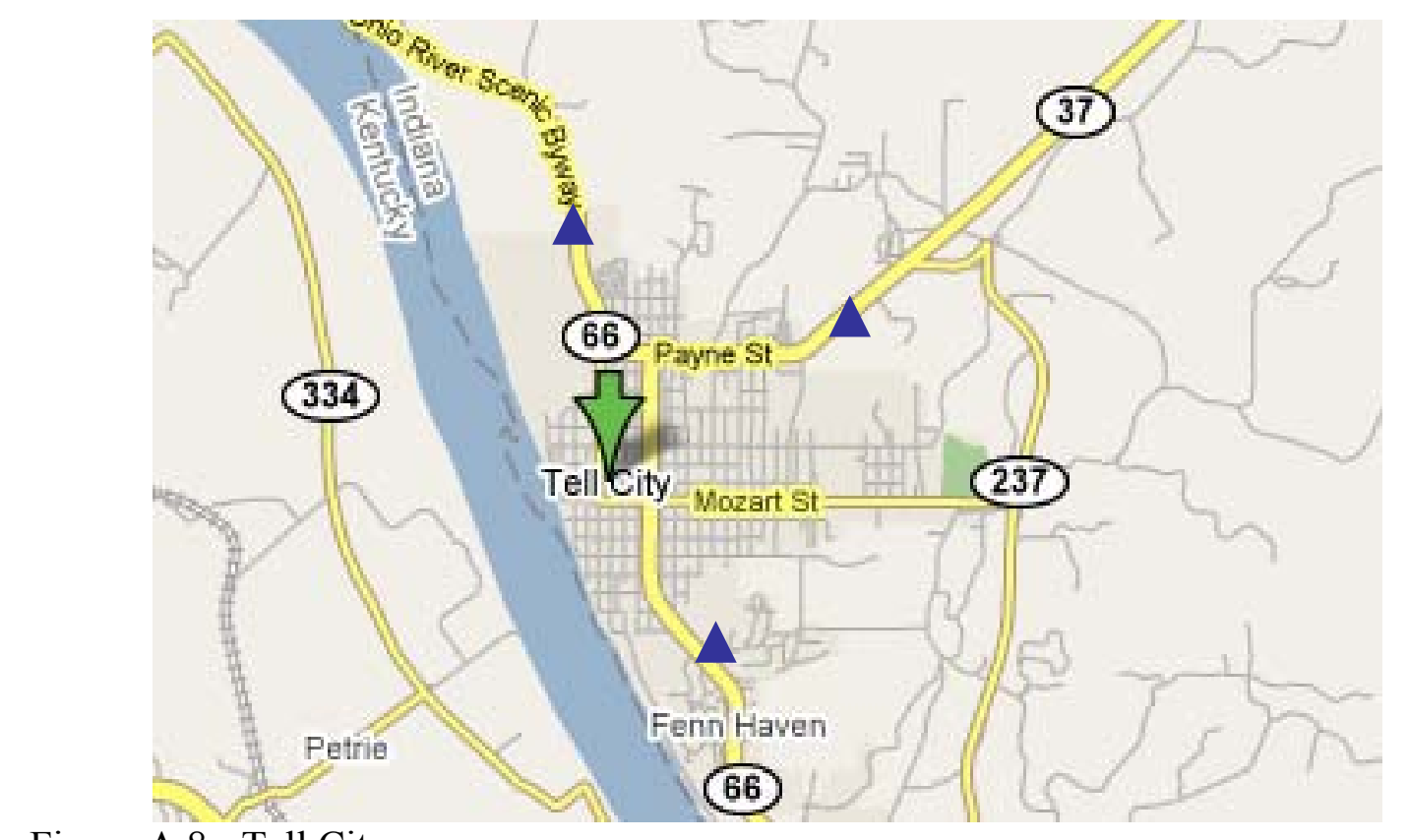

Figure A.8- Tell City

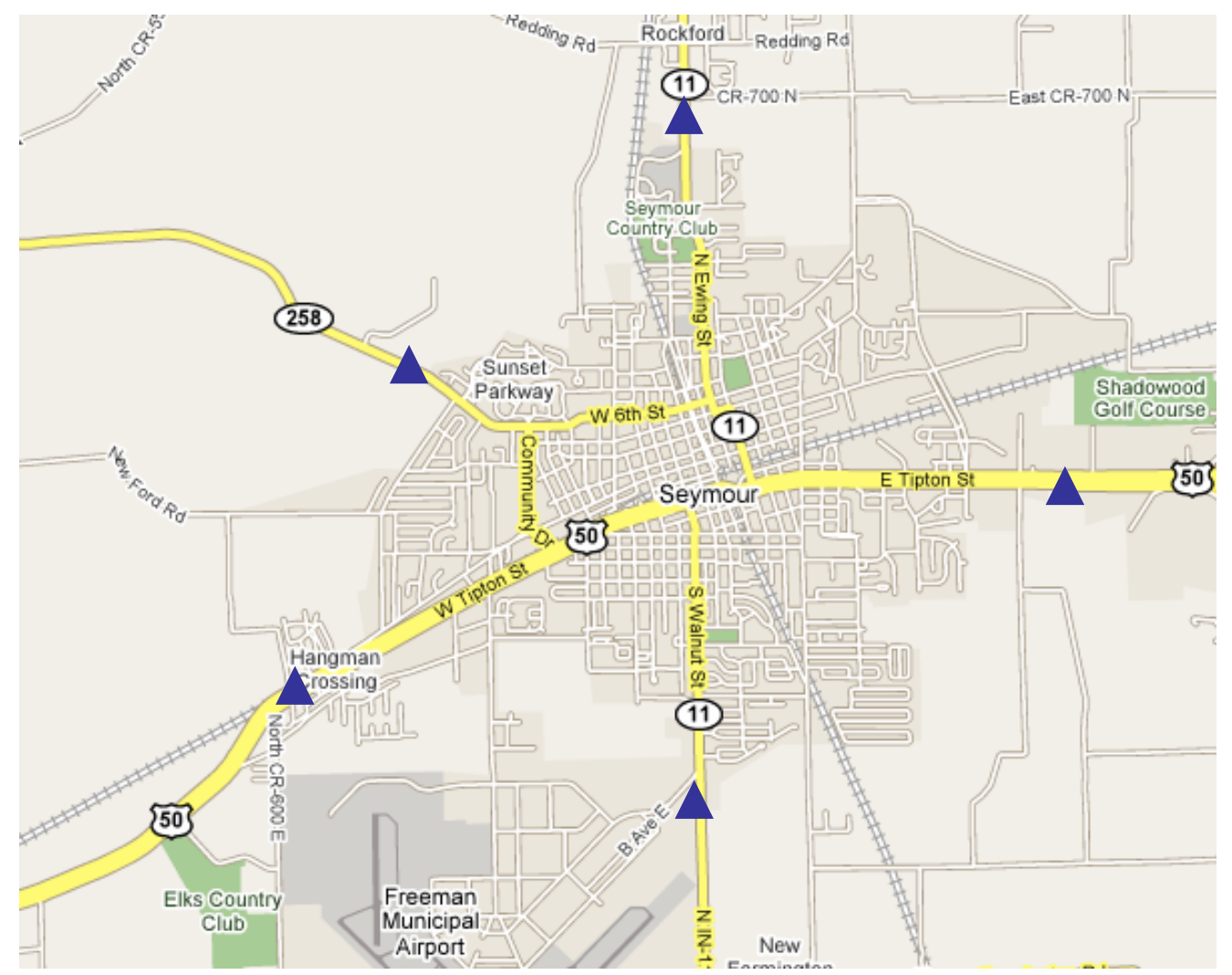

Figure A.9- Seymour 


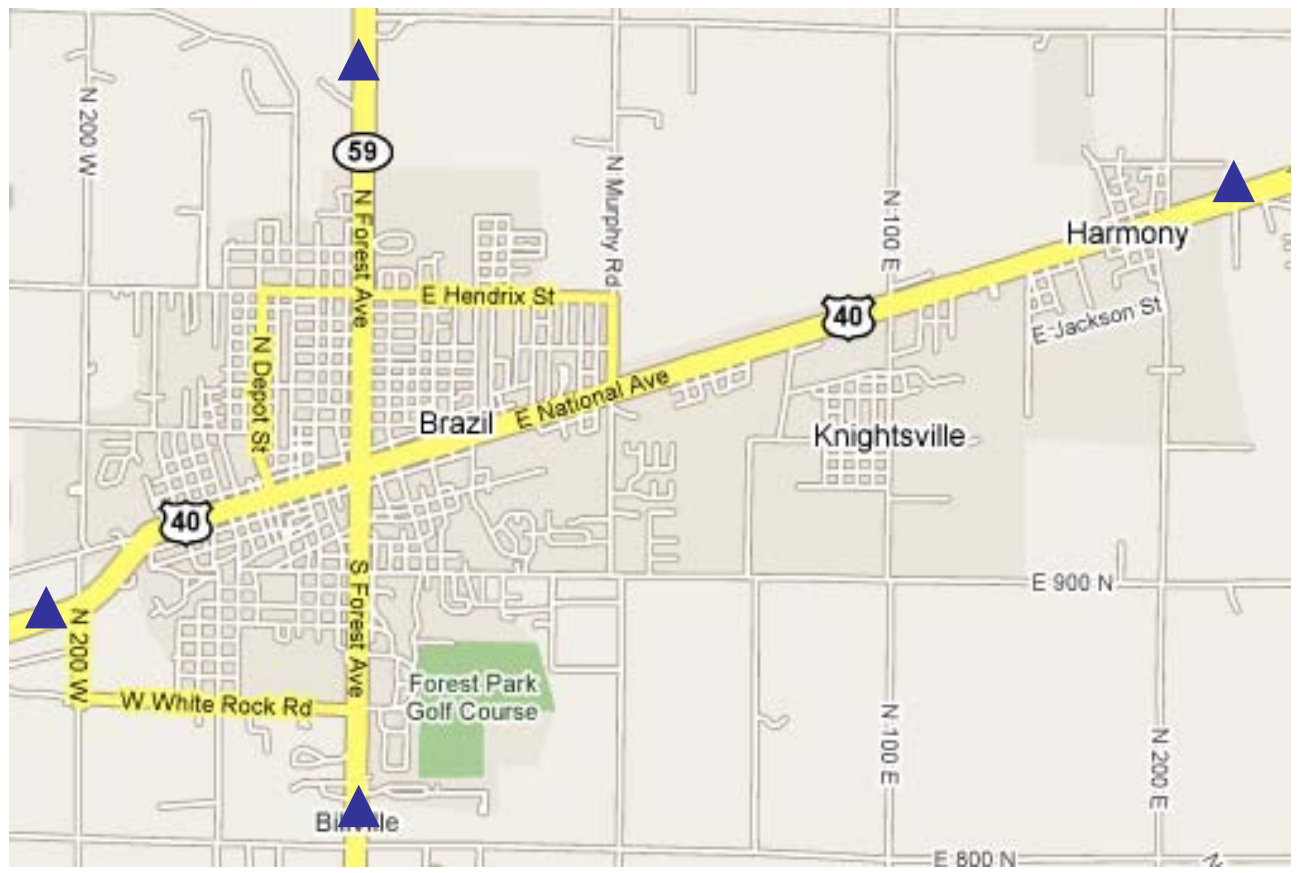

Figure A.10- Brazil

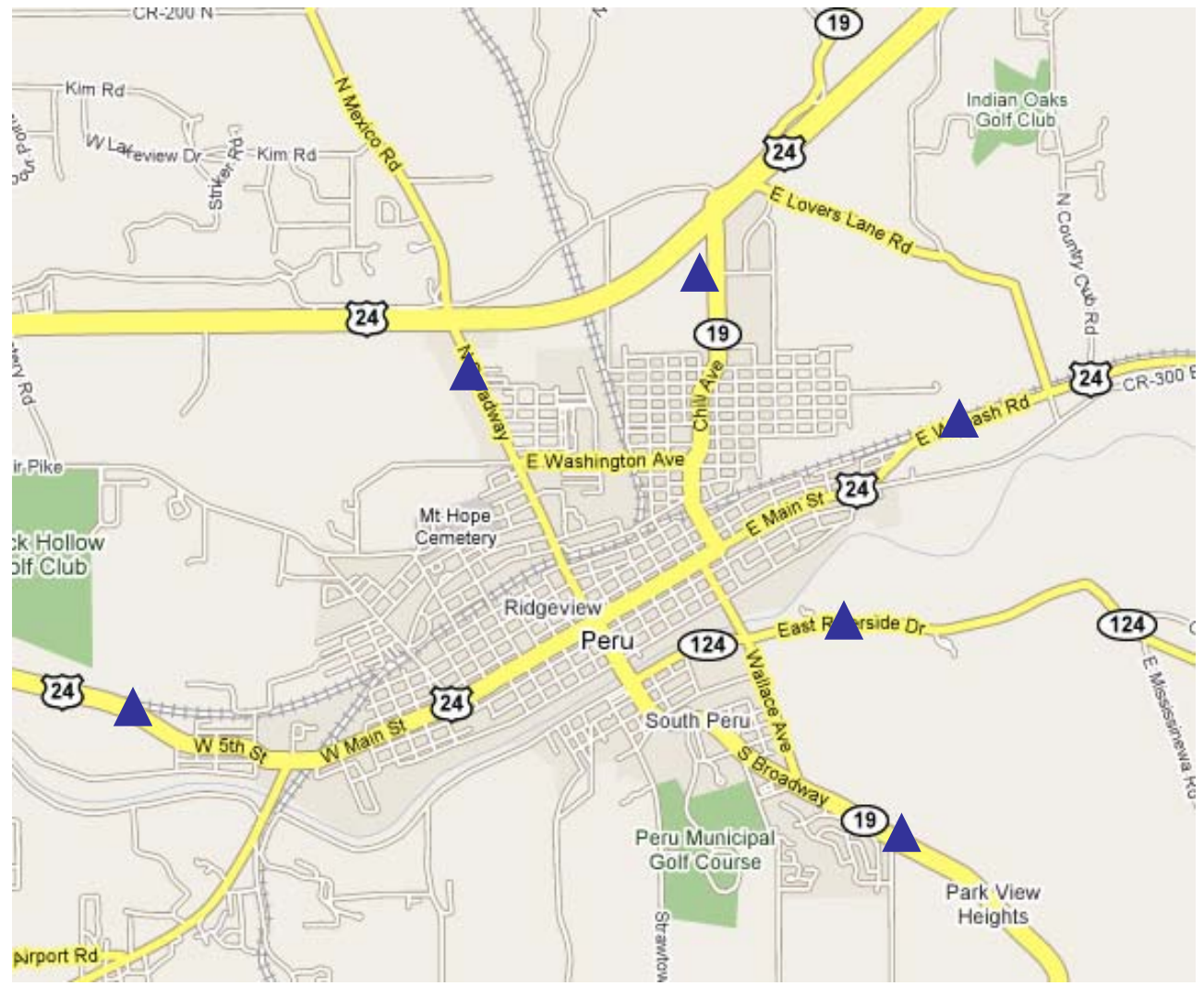

Figure A.11- Peru 


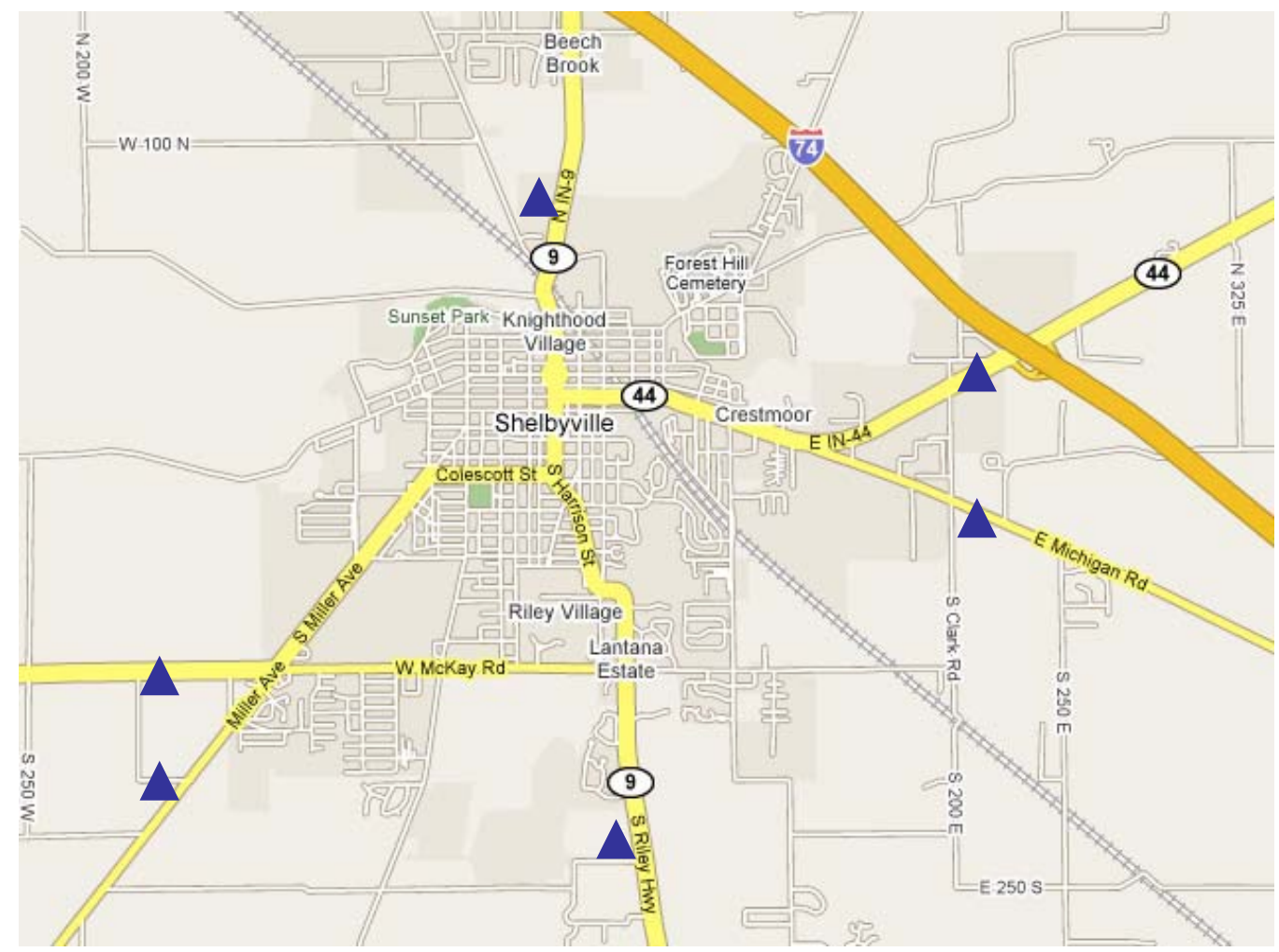

Figure A.12- Shelbyville

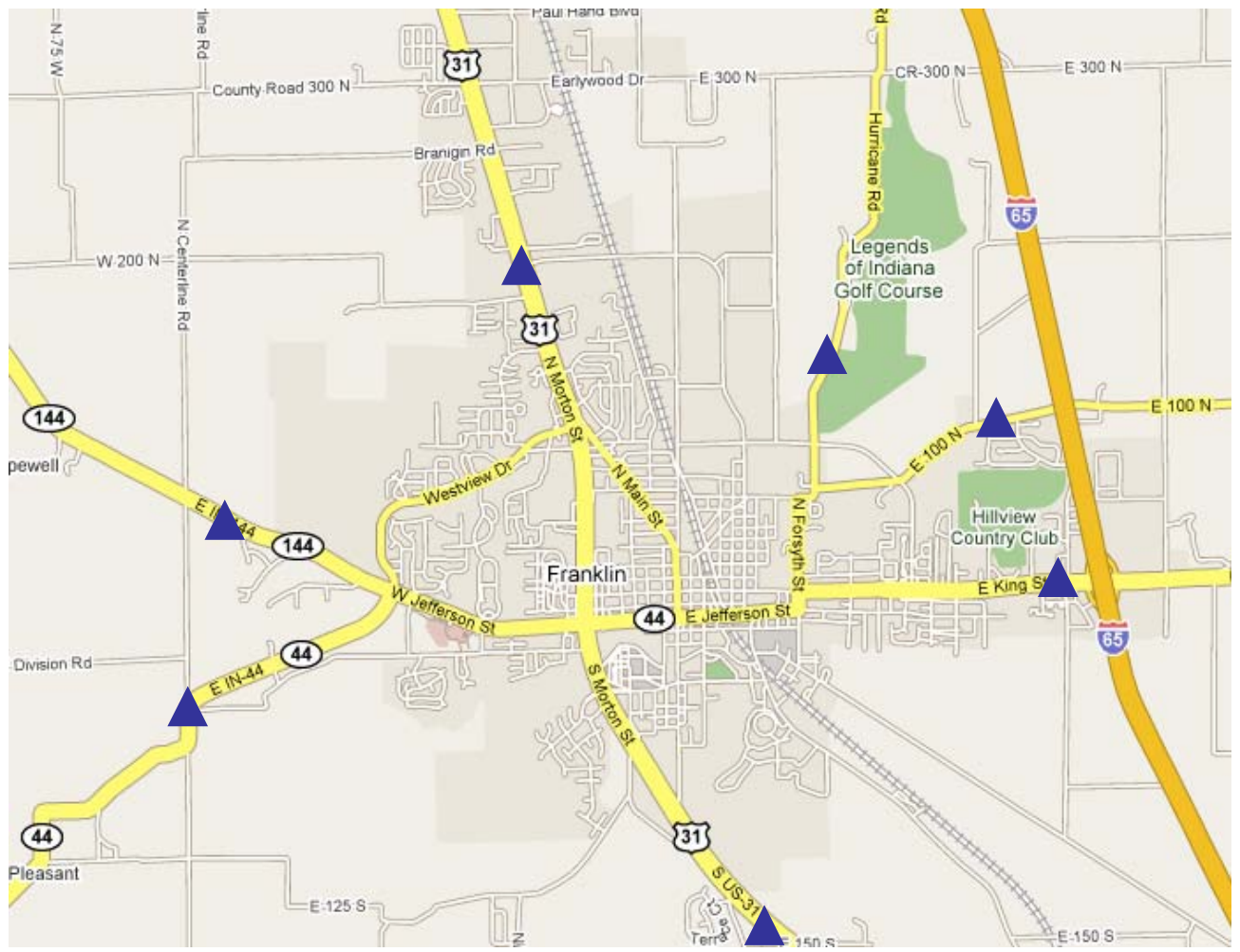

Figure A.13- Franklin 


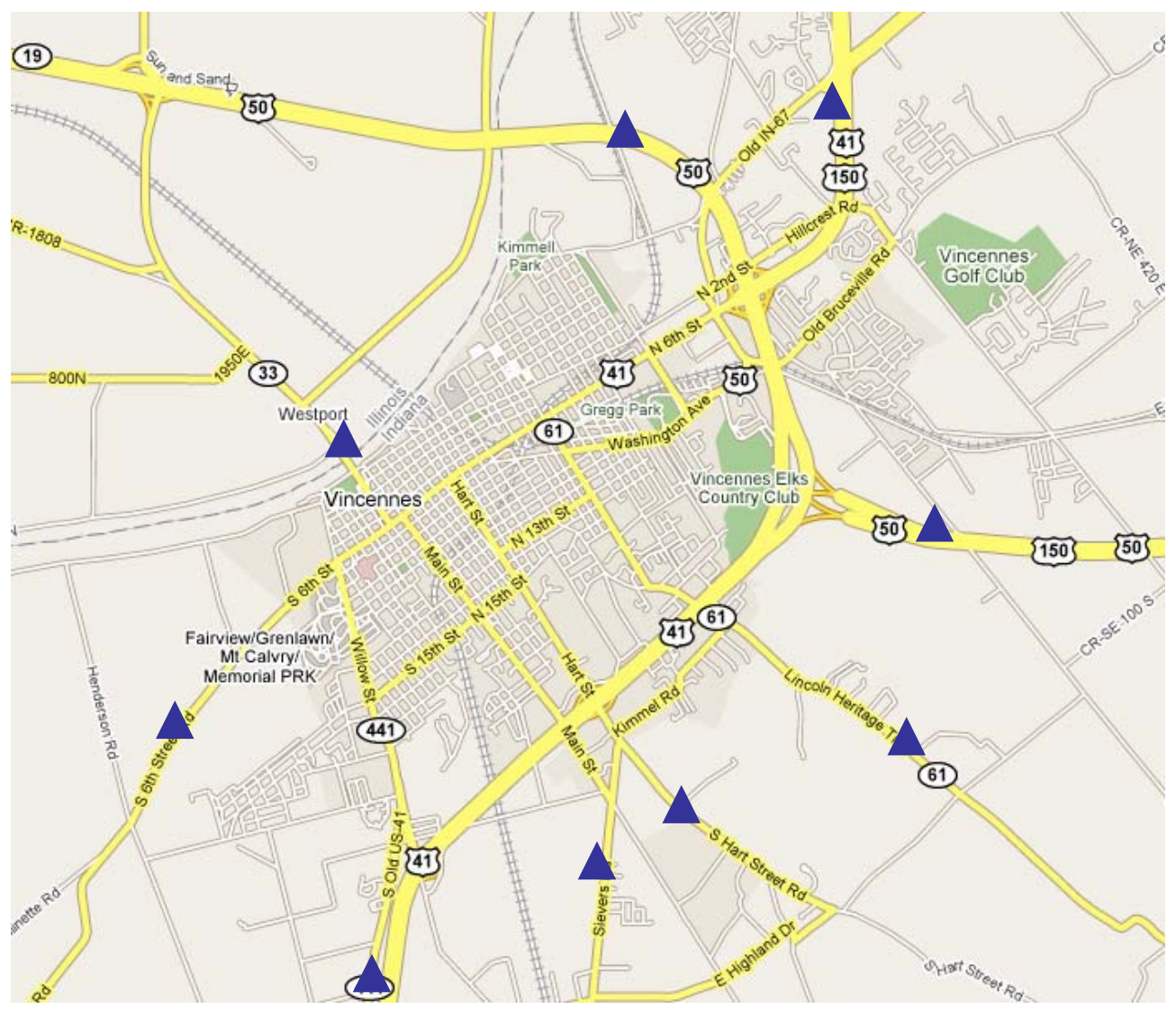

Figure A.14- Vincennes

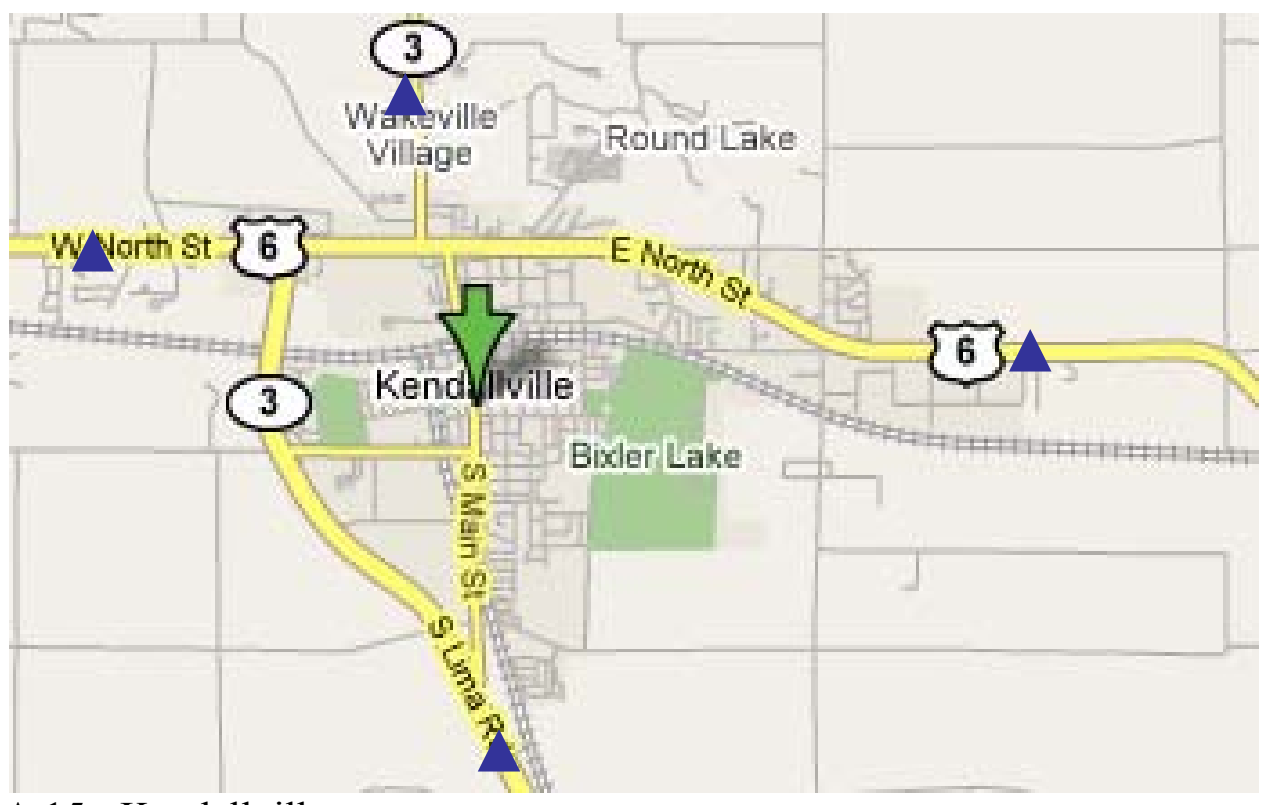

Figure A.15- Kendallville 


\section{$\underline{\text { Appendix B }}$}

Parameters Used in the Estimation of Logit Model are described in this section.

Table B.1- New Castle

\begin{tabular}{|c|c|c|c|c|c|c|c|c|c|}
\hline Origin & Destination & Yij & ADTj & $\mathrm{NLj}$ & $\mathrm{NMCj}$ & $\begin{array}{l}\text { RTEC } \\
\text { ONij }\end{array}$ & IEF & PA & $\begin{array}{l}\text { ADTj/ } \\
\text { sum }\end{array}$ \\
\hline \multirow[t]{8}{*}{ CR $100 \mathrm{~W}$} & CR $100 \mathrm{~W}$ & 0.782 & 1021 & 2 & 0 & 0 & 1 & 0 & 0.034 \\
\hline & Dublin Pike & 0.000 & 957.5 & 2 & 0 & 0 & 0 & 0 & 0.032 \\
\hline & SR-38 E & 0.018 & 2280 & 2 & 0 & 0 & 0 & 1 & 0.075 \\
\hline & SR-3 S & 0.085 & 9170 & 4 & 0 & 0 & 0 & 1 & 0.302 \\
\hline & SR-103 S & 0.000 & 2295 & 2 & 0 & 0 & 0 & 0 & 0.076 \\
\hline & SR-103 N & 0.020 & 1600 & 2 & 0 & 0 & 0 & 0 & 0.053 \\
\hline & SR-3 N & 0.095 & 7050 & 4 & 1 & 0 & 0 & 1 & 0.232 \\
\hline & SR-38 W & 0.000 & 5495 & 2 & 0 & 0 & 0 & 1 & 0.181 \\
\hline \multirow[t]{8}{*}{ Dublin Pike } & Dublin Pike & 0.880 & 957.5 & 2 & 0 & 0 & 1 & 0 & 0.032 \\
\hline & SR-38 E & 0.000 & 2280 & 2 & 0 & 0 & 0 & 1 & 0.075 \\
\hline & SR-3 S & 0.000 & 9170 & 4 & 0 & 0 & 0 & 1 & 0.302 \\
\hline & SR-103 S & 0.000 & 2295 & 2 & 0 & 0 & 0 & 0 & 0.076 \\
\hline & SR-103 N & 0.014 & 1600 & 2 & 0 & 1 & 0 & 0 & 0.053 \\
\hline & SR-3 N & 0.032 & 7050 & 4 & 1 & 0 & 0 & 1 & 0.232 \\
\hline & SR-38 W & 0.074 & 5495 & 2 & 0 & 0 & 0 & 1 & 0.181 \\
\hline & CR $100 \mathrm{~W}$ & 0.000 & 1021 & 2 & 0 & 0 & 0 & 0 & 0.034 \\
\hline \multirow[t]{8}{*}{ SR-38 E } & SR-38 E & 0.623 & 2280 & 2 & 0 & 0 & 1 & 1 & 0.075 \\
\hline & SR-3 S & 0.000 & 9170 & 4 & 0 & 0 & 0 & 1 & 0.302 \\
\hline & SR-103 S & 0.001 & 2295 & 2 & 0 & 0 & 0 & 0 & 0.076 \\
\hline & SR-103 N & 0.028 & 1600 & 2 & 0 & 0 & 0 & 0 & 0.053 \\
\hline & SR-3 N & 0.093 & 7050 & 4 & 1 & 0 & 0 & 1 & 0.232 \\
\hline & SR-38 W & 0.247 & 5495 & 2 & 0 & 1 & 0 & 1 & 0.181 \\
\hline & CR $100 \mathrm{~W}$ & 0.008 & 1021 & 2 & 0 & 0 & 0 & 0 & 0.034 \\
\hline & Dublin Pike & 0.000 & 957.5 & 2 & 0 & 0 & 0 & 0 & 0.032 \\
\hline \multirow[t]{8}{*}{ SR-3 S } & SR-3 S & 0.749 & 9170 & 4 & 0 & 0 & 1 & 1 & 0.302 \\
\hline & SR-103 S & 0.000 & 2295 & 2 & 0 & 0 & 0 & 0 & 0.076 \\
\hline & SR-103 N & 0.011 & 1600 & 2 & 0 & 0 & 0 & 0 & 0.053 \\
\hline & SR-3 N & 0.165 & 7050 & 4 & 1 & 1 & 0 & 1 & 0.232 \\
\hline & SR-38 W & 0.066 & 5495 & 2 & 0 & 0 & 0 & 1 & 0.181 \\
\hline & CR $100 \mathrm{~W}$ & 0.009 & 1021 & 2 & 0 & 0 & 0 & 0 & 0.034 \\
\hline & Dublin Pike & 0.000 & 957.5 & 2 & 0 & 0 & 0 & 0 & 0.032 \\
\hline & SR-38 E & 0.000 & 2280 & 2 & 0 & 0 & 0 & 1 & 0.075 \\
\hline \multirow[t]{4}{*}{ SR-103 S } & SR-103 S & 0.992 & 2295 & 2 & 0 & 0 & 1 & 0 & 0.076 \\
\hline & SR-103 N & 0.008 & 1600 & 2 & 0 & 1 & 0 & 0 & 0.053 \\
\hline & SR-3 N & 0.000 & 7050 & 4 & 1 & 0 & 0 & 1 & 0.232 \\
\hline & SR-38 W & 0.000 & 5495 & 2 & 0 & 0 & 0 & 1 & 0.181 \\
\hline
\end{tabular}




\begin{tabular}{|l|l|r|r|r|r|r|r|r|r|}
\hline & CR 100 W & 0.000 & 1021 & 2 & 0 & 0 & 0 & 0 & 0.034 \\
\hline & Dublin Pike & 0.000 & 957.5 & 2 & 0 & 0 & 0 & 0 & 0.032 \\
\hline & SR-38 E & 0.001 & 2280 & 2 & 0 & 0 & 0 & 1 & 0.075 \\
\hline & SR-3 S & 0.000 & 9170 & 4 & 0 & 0 & 0 & 1 & 0.302 \\
\hline SR-103 N & SR-103 N & 0.810 & 1600 & 2 & 0 & 0 & 1 & 0 & 0.053 \\
\hline & SR-3 N & 0.000 & 7050 & 4 & 1 & 0 & 0 & 1 & 0.232 \\
\hline & SR-38 W & 0.057 & 5495 & 2 & 0 & 0 & 0 & 1 & 0.181 \\
\hline & CR 100 W & 0.012 & 1021 & 2 & 0 & 0 & 0 & 0 & 0.034 \\
\hline & Dublin Pike & 0.008 & 957.5 & 2 & 0 & 0 & 0 & 0 & 0.032 \\
\hline & SR-38 E & 0.040 & 2280 & 2 & 0 & 0 & 0 & 1 & 0.075 \\
\hline & SR-3 S & 0.060 & 9170 & 4 & 0 & 0 & 0 & 1 & 0.302 \\
\hline & SR-103 S & 0.013 & 2295 & 2 & 0 & 1 & 0 & 0 & 0.076 \\
\hline & SR-3 N & 0.715 & 7050 & 4 & 1 & 0 & 1 & 1 & 0.232 \\
\hline & SR-38 W & 0.023 & 5495 & 2 & 0 & 0 & 0 & 1 & 0.181 \\
\hline & CR 100 W & 0.014 & 1021 & 2 & 0 & 0 & 0 & 0 & 0.034 \\
\hline & Dublin Pike & 0.004 & 957.5 & 2 & 0 & 0 & 0 & 0 & 0.032 \\
\hline & SR-38 E & 0.030 & 2280 & 2 & 0 & 0 & 0 & 1 & 0.075 \\
\hline & SR-3 S & 0.214 & 9170 & 4 & 0 & 1 & 0 & 1 & 0.302 \\
\hline & SR-103 S & 0.000 & 2295 & 2 & 0 & 0 & 0 & 0 & 0.076 \\
\hline & SR-103 N & 0.000 & 1600 & 2 & 0 & 0 & 0 & 0 & 0.053 \\
\hline & SR-38 W & 0.729 & 5495 & 2 & 0 & 0 & 1 & 1 & 0.181 \\
\hline & CR 100 W & 0.000 & 1021 & 2 & 0 & 0 & 0 & 0 & 0.034 \\
\hline & Dublin Pike & 0.013 & 957.5 & 2 & 0 & 0 & 0 & 0 & 0.032 \\
\hline & SR-38 E & 0.102 & 2280 & 2 & 0 & 1 & 0 & 1 & 0.075 \\
\hline & SR-3 S & 0.110 & 9170 & 4 & 0 & 0 & 0 & 1 & 0.302 \\
\hline & SR-103 S & 0.000 & 2295 & 2 & 0 & 0 & 0 & 0 & 0.076 \\
\hline & SR-103 N & 0.017 & 1600 & 2 & 0 & 0 & 0 & 0 & 0.053 \\
\hline & SR-3 N & 0.029 & 7050 & 4 & 1 & 0 & 0 & 1 & 0.232 \\
\hline
\end{tabular}


Table B.2- Martinsville

\begin{tabular}{|r|l|r|r|r|r|r|r|r|r|}
\hline Origin & Destination & \multicolumn{1}{|c|}{ Yij } & \multicolumn{1}{c|}{ ADTj } & NLj & NMCj & $\begin{array}{c}\text { RTE } \\
\text { CONij }\end{array}$ & IEF & PA & $\begin{array}{c}\text { ADTj/ } \\
\text { sum }\end{array}$ \\
\hline SR-37 S & SR-37 S & 0.305 & 23220 & 4 & 0 & 0 & 1 & 1 & 0.299 \\
\hline & SR-39 N & 0.270 & 21060 & 2 & 0 & 1 & 0 & 1 & 0.271 \\
\hline & SR-252 E & 0.031 & 5090 & 2 & 0 & 0 & 0 & 0 & 0.065 \\
\hline & SR-44 E & 0.029 & 3520 & 2 & 0 & 1 & 0 & 0 & 0.045 \\
\hline & SR-37 N & 0.365 & 24870 & 4 & 0 & 1 & 0 & 1 & 0.320 \\
\hline SR-39 N & SR-39 N & 0.598 & 21060 & 2 & 0 & 0 & 1 & 1 & 0.271 \\
\hline & SR-252 E & 0.036 & 5090 & 2 & 0 & 0 & 0 & 1 & 0.065 \\
\hline & SR-44 E & 0.015 & 3520 & 2 & 0 & 0 & 0 & 0 & 0.045 \\
\hline & SR-37 N & 0.054 & 24870 & 4 & 0 & 0 & 0 & 1 & 0.320 \\
\hline & SR-37 S & 0.297 & 23220 & 4 & 0 & 1 & 0 & 1 & 0.299 \\
\hline SR-252 E & SR-252 E & 0.344 & 5090 & 2 & 0 & 0 & 1 & 0 & 0.065 \\
\hline & SR-44 E & 0.026 & 3520 & 2 & 0 & 0 & 0 & 0 & 0.045 \\
\hline & SR-37 N & 0.342 & 24870 & 4 & 0 & 1 & 0 & 1 & 0.320 \\
\hline & SR-37 S & 0.141 & 23220 & 4 & 0 & 0 & 0 & 1 & 0.299 \\
\hline & SR-39 N & 0.147 & 21060 & 2 & 0 & 0 & 0 & 1 & 0.271 \\
\hline SR-44 E & SR-44 E & 0.576 & 3520 & 2 & 0 & 0 & 1 & 0 & 0.045 \\
\hline & SR-37 N & 0.104 & 24870 & 4 & 0 & 0 & 0 & 1 & 0.320 \\
\hline & SR-37 S & 0.193 & 23220 & 4 & 0 & 1 & 0 & 1 & 0.299 \\
\hline & SR-39 N & 0.090 & 21060 & 4 & 0 & 0 & 0 & 1 & 0.271 \\
\hline & SR-252 E & 0.037 & 5090 & 2 & 0 & 0 & 0 & 0 & 0.065 \\
\hline & SR-37 N & 0.529 & 24870 & 4 & 0 & 0 & 1 & 1 & 0.320 \\
\hline & SR-37 S & 0.341 & 23220 & 4 & 0 & 1 & 0 & 1 & 0.299 \\
\hline & SR-39 N & 0.045 & 21060 & 2 & 0 & 0 & 0 & 1 & 0.271 \\
\hline & SR-252 E & 0.070 & 5090 & 2 & 0 & 0 & 0 & 0 & 0.065 \\
\hline & SR-44 E & 0.015 & 3520 & 2 & 0 & 0 & 0 & 0 & 0.045 \\
\hline
\end{tabular}


Table B.3- Greensburg

\begin{tabular}{|l|l|l|r|r|r|r|r|r|r|}
\hline Origin & Destination & \multicolumn{1}{c|}{ Yij } & \multicolumn{1}{c|}{ ADTj } & NLj & NMCj & $\begin{array}{c}\text { RTE } \\
\text { CONij }\end{array}$ & IEF & PA & $\begin{array}{c}\text { ADTj/ } \\
\text { sum }\end{array}$ \\
\hline SR-3 W & SR-3 W & 0.431 & 10640 & 4 & 0 & 0 & 1 & 1 & 0.269 \\
\hline & IN-46 E & 0.006 & 4470 & 2 & 0 & 0 & 0 & 0 & 0.113 \\
\hline & SR-3 N & 0.506 & 14550 & 4 & 0 & 1 & 0 & 1 & 0.368 \\
\hline & US-421 S & 0.035 & 6440 & 2 & 0 & 0 & 0 & 1 & 0.163 \\
\hline & US-421 N & 0.022 & 3450 & 2 & 0 & 0 & 0 & 1 & 0.087 \\
\hline IN-46 E & IN-46 E & 0.969 & 4470 & 2 & 0 & 0 & 1 & 0 & 0.113 \\
\hline & SR-3 N & 0.004 & 14550 & 4 & 0 & 0 & 0 & 1 & 0.368 \\
\hline & US-421 S & 0.008 & 6440 & 2 & 0 & 0 & 0 & 1 & 0.163 \\
\hline & US-421 N & 0.005 & 3450 & 2 & 0 & 0 & 0 & 1 & 0.087 \\
\hline & SR-3 W & 0.014 & 10640 & 4 & 0 & 1 & 0 & 1 & 0.269 \\
\hline SR-3 N & SR-3 N & 0.594 & 14550 & 4 & 0 & 0 & 1 & 1 & 0.368 \\
\hline & US-421 S & 0.035 & 6440 & 2 & 0 & 0 & 0 & 1 & 0.163 \\
\hline & US-421 N & 0.000 & 3450 & 2 & 0 & 0 & 0 & 1 & 0.087 \\
\hline & SR-3 W & 0.370 & 10640 & 4 & 0 & 1 & 0 & 1 & 0.269 \\
\hline & IN-46 E & 0.001 & 4470 & 2 & 0 & 0 & 0 & 0 & 0.113 \\
\hline US-421 S & US-421 S & 0.721 & 6440 & 2 & 0 & 0 & 1 & 1 & 0.163 \\
\hline & US-421 N & 0.137 & 3450 & 2 & 0 & 1 & 0 & 1 & 0.087 \\
\hline & SR-3 W & 0.058 & 10640 & 4 & 0 & 0 & 0 & 1 & 0.269 \\
\hline & IN-46 E & 0.006 & 4470 & 2 & 0 & 0 & 0 & 0 & 0.113 \\
\hline & SR-3 N & 0.079 & 14550 & 4 & 0 & 0 & 0 & 1 & 0.368 \\
\hline & US-421 N & 0.669 & 3450 & 2 & 0 & 0 & 1 & 1 & 0.087 \\
\hline & SR-3 W & 0.069 & 10640 & 4 & 0 & 0 & 0 & 1 & 0.269 \\
\hline & IN-46 E & 0.007 & 4470 & 2 & 0 & 0 & 0 & 0 & 0.113 \\
\hline & SR-3 N & 0.000 & 14550 & 4 & 0 & 0 & 0 & 1 & 0.368 \\
\hline & US-421 S & 0.255 & 6440 & 2 & 0 & 1 & 0 & 1 & 0.163 \\
\hline
\end{tabular}


Table B.4- Bluffton

\begin{tabular}{|c|c|c|c|c|c|c|c|c|c|}
\hline Origin & Destination & Yij & ADTj & $\mathrm{NLj}$ & $\mathrm{NMCj}$ & $\begin{array}{l}\text { RTEC } \\
\text { ONij }\end{array}$ & IEF & PA & \begin{tabular}{|l} 
ADTj/ \\
sum
\end{tabular} \\
\hline \multirow[t]{7}{*}{ SR-1 S } & SR-1 S & 0.731 & 4420 & 2 & 0 & 0 & 1 & 1 & 0.168 \\
\hline & SR-116 N & 0.053 & 3810 & 2 & 0 & 0 & 0 & 1 & 0.145 \\
\hline & SR-1 N & 0.182 & 9090 & 2 & 1 & 1 & 0 & 1 & 0.346 \\
\hline & SR-124 W & 0.030 & 1760 & 2 & 0 & 0 & 0 & 1 & 0.067 \\
\hline & SR-116 S & 0.001 & 2420 & 2 & 0 & 0 & 0 & 1 & 0.092 \\
\hline & SR-124 E & 0.003 & 3360 & 2 & 0 & 0 & 0 & 1 & 0.128 \\
\hline & SR-201 E & 0.000 & 1430 & 2 & 0 & 0 & 0 & 0 & 0.054 \\
\hline \multirow[t]{7}{*}{ SR-116 N } & SR-116 N & 0.802 & 3810 & 2 & 0 & 0 & 1 & 1 & 0.145 \\
\hline & SR-1 N & 0.001 & 9090 & 2 & 1 & 0 & 0 & 1 & 0.346 \\
\hline & SR-124 W & 0.047 & 1760 & 2 & 0 & 0 & 0 & 1 & 0.067 \\
\hline & SR-116 S & 0.057 & 2420 & 2 & 0 & 1 & 0 & 1 & 0.092 \\
\hline & SR-124 E & 0.026 & 3360 & 2 & 0 & 0 & 0 & 1 & 0.128 \\
\hline & SR-201 E & 0.005 & 1430 & 2 & 0 & 0 & 0 & 0 & 0.054 \\
\hline & SR-1 S & 0.062 & 4420 & 2 & 0 & 0 & 0 & 1 & 0.168 \\
\hline \multirow[t]{7}{*}{ SR-1 N } & SR-1 N & 0.857 & 9090 & 2 & 1 & 0 & 1 & 1 & 0.346 \\
\hline & SR-124 W & 0.013 & 1760 & 2 & 0 & 0 & 0 & 1 & 0.067 \\
\hline & SR-116 S & 0.028 & 2420 & 2 & 0 & 0 & 0 & 1 & 0.092 \\
\hline & SR-124 E & 0.004 & 3360 & 2 & 0 & 0 & 0 & 1 & 0.128 \\
\hline & SR-201 E & 0.009 & 1430 & 2 & 0 & 0 & 0 & 0 & 0.054 \\
\hline & SR-1 S & 0.088 & 4420 & 2 & 0 & 1 & 0 & 1 & 0.168 \\
\hline & SR-116 N & 0.000 & 3810 & 2 & 0 & 0 & 0 & 1 & 0.145 \\
\hline \multirow[t]{7}{*}{ SR-124 W } & SR-124 W & 0.547 & 1760 & 2 & 0 & 0 & 1 & 1 & 0.067 \\
\hline & SR-116 S & 0.053 & 2420 & 2 & 0 & 0 & 0 & 1 & 0.092 \\
\hline & SR-124 E & 0.134 & 3360 & 2 & 0 & 1 & 0 & 1 & 0.128 \\
\hline & SR-201 E & 0.021 & 1430 & 2 & 0 & 0 & 0 & 0 & 0.054 \\
\hline & SR-1 S & 0.075 & 4420 & 2 & 0 & 0 & 0 & 1 & 0.168 \\
\hline & SR-116 N & 0.102 & 3810 & 2 & 0 & 0 & 0 & 1 & 0.145 \\
\hline & SR-1 N & 0.068 & 9090 & 2 & 1 & 0 & 0 & 1 & 0.346 \\
\hline \multirow[t]{7}{*}{ SR-116 S } & SR-116 S & 0.764 & 2420 & 2 & 0 & 0 & 1 & 1 & 0.092 \\
\hline & SR-124 E & 0.000 & 3360 & 2 & 0 & 0 & 0 & 1 & 0.128 \\
\hline & SR-201 E & 0.000 & 1430 & 2 & 0 & 0 & 0 & 0 & 0.054 \\
\hline & SR-1 S & 0.002 & 4420 & 2 & 0 & 0 & 0 & 1 & 0.168 \\
\hline & SR-116 N & 0.090 & 3810 & 2 & 0 & 1 & 0 & 1 & 0.145 \\
\hline & SR-1 N & 0.106 & 9090 & 2 & 1 & 1 & 0 & 1 & 0.346 \\
\hline & SR-124 W & 0.039 & 1760 & 2 & 0 & 1 & 0 & 1 & 0.067 \\
\hline \multirow[t]{7}{*}{ SR-124 E } & SR-124 E & 0.886 & 3360 & 2 & 0 & 0 & 1 & 1 & 0.128 \\
\hline & SR-201 E & 0.000 & 1430 & 2 & 0 & 0 & 0 & 0 & 0.054 \\
\hline & SR-1 S & 0.004 & 4420 & 2 & 0 & 0 & 0 & 1 & 0.168 \\
\hline & SR-116 N & 0.029 & 3810 & 2 & 0 & 0 & 0 & 1 & 0.145 \\
\hline & SR-1 N & 0.011 & 9090 & 2 & 1 & 0 & 0 & 1 & 0.346 \\
\hline & SR-124 W & 0.070 & 1760 & 2 & 0 & 1 & 0 & 1 & 0.067 \\
\hline & SR-116 S & 0.000 & 2420 & 2 & 0 & 0 & 0 & 1 & 0.092 \\
\hline SR-201 E & SR-201 E & 0.905 & 1430 & 2 & 0 & 0 & 1 & 0 & 0.054 \\
\hline
\end{tabular}




\begin{tabular}{|l|l|l|r|r|r|r|r|r|r|}
\hline & SR-1 S & 0.000 & 4420 & 2 & 0 & 0 & 0 & 1 & 0.168 \\
\hline & SR-116 N & 0.014 & 3810 & 2 & 0 & 0 & 0 & 1 & 0.145 \\
\hline & SR-1 N & 0.055 & 9090 & 2 & 1 & 1 & 0 & 1 & 0.346 \\
\hline & SR-124 W & 0.026 & 1760 & 2 & 0 & 1 & 0 & 1 & 0.067 \\
\hline & SR-116 S & 0.000 & 2420 & 2 & 0 & 0 & 0 & 1 & 0.092 \\
\hline & SR-124 E & 0.000 & 3360 & 2 & 0 & 0 & 0 & 1 & 0.128 \\
\hline
\end{tabular}

Table B.5- Jasper

\begin{tabular}{|l|l|r|r|r|r|r|r|r|l|}
\hline Origin & Destination & \multicolumn{1}{|c|}{ Yij } & \multicolumn{1}{c|}{ ADTj } & NLj & NMCj & $\begin{array}{l}\text { RTEC } \\
\text { ONij }\end{array}$ & IEF & PA & $\begin{array}{l}\text { ADTj/ } \\
\text { sum }\end{array}$ \\
\hline SR-56 W & SR-56 W & 0.878 & 11190 & 2 & 0 & 0 & 1 & 1 & 0.217 \\
\hline & US-231 N & 0.016 & 9560 & 2 & 0 & 0 & 0 & 0 & 0.185 \\
\hline & SR-162 S & 0.024 & 10670 & 2 & 0 & 0 & 0 & 0 & 0.207 \\
\hline & US-231 S & 0.043 & 14260 & 2 & 0 & 0 & 0 & 1 & 0.276 \\
\hline & SR-164 E & 0.039 & 5950 & 2 & 0 & 1 & 0 & 0 & 0.115 \\
\hline US-231 N & US-231 N & 0.845 & 9560 & 2 & 0 & 0 & 1 & 0 & 0.185 \\
\hline & SR-162 S & 0.000 & 10670 & 2 & 0 & 0 & 0 & 0 & 0.207 \\
\hline & US-231 S & 0.121 & 14260 & 2 & 0 & 1 & 0 & 1 & 0.276 \\
\hline & SR-164 E & 0.016 & 5950 & 2 & 0 & 0 & 0 & 0 & 0.115 \\
\hline & SR-56 W & 0.019 & 11190 & 2 & 0 & 0 & 0 & 1 & 0.217 \\
\hline SR-162 S & SR-162 S & 0.894 & 10670 & 2 & 0 & 0 & 1 & 0 & 0.207 \\
\hline & US-231 S & 0.059 & 14260 & 2 & 0 & 0 & 0 & 1 & 0.276 \\
\hline & SR-164 E & 0.022 & 5950 & 2 & 0 & 0 & 0 & 0 & 0.115 \\
\hline & SR-56 W & 0.025 & 11190 & 2 & 0 & 0 & 0 & 1 & 0.217 \\
\hline & US-231 N & 0.000 & 9560 & 2 & 0 & 1 & 0 & 0 & 0.185 \\
\hline & US-231 S & 0.841 & 14260 & 2 & 0 & 0 & 1 & 1 & 0.276 \\
\hline & SR-164 E & 0.000 & 5950 & 2 & 0 & 0 & 0 & 0 & 0.115 \\
\hline & SR-56 W & 0.034 & 11190 & 2 & 0 & 0 & 0 & 1 & 0.217 \\
\hline & US-231 N & 0.081 & 9560 & 2 & 0 & 1 & 0 & 0 & 0.185 \\
\hline & SR-162 S & 0.044 & 10670 & 2 & 0 & 0 & 0 & 0 & 0.207 \\
\hline & SR-164 E & 0.863 & 5950 & 2 & 0 & 0 & 1 & 0 & 0.115 \\
\hline & SR-56 W & 0.073 & 11190 & 2 & 0 & 1 & 0 & 1 & 0.217 \\
\hline & US-231 N & 0.025 & 9560 & 2 & 0 & 0 & 0 & 0 & 0.185 \\
\hline & SR-162 S & 0.039 & 10670 & 2 & 0 & 0 & 0 & 0 & 0.207 \\
\hline & US-231 S & 0.000 & 14260 & 2 & 0 & 0 & 0 & 1 & 0.276 \\
\hline
\end{tabular}


Table B.6- Bedford

\begin{tabular}{|c|c|c|c|c|c|c|c|c|c|}
\hline Origin & Destination & $Y_{i j}$ & ADTj & $\mathrm{NLj}$ & $\mathrm{NMCj}$ & $\begin{array}{l}\text { RTEC } \\
\text { ONij }\end{array}$ & IEF & PA & $\begin{array}{l}\text { ADTj/ } \\
\text { sum }\end{array}$ \\
\hline \multirow[t]{6}{*}{ US-37 S } & US-37 S & 0.573 & 22370 & 4 & 0 & 0 & 1 & 1 & 0.398 \\
\hline & SR-450 W & 0.001 & 2350 & 2 & 0 & 0 & 0 & 0 & 0.042 \\
\hline & US-50 E & 0.045 & 5610 & 2 & 0 & 0 & 0 & 1 & 0.100 \\
\hline & SR-58 E & 0.000 & 600 & 2 & 0 & 0 & 0 & 0 & 0.011 \\
\hline & SR-158 W & 0.021 & 3500 & 2 & 0 & 0 & 0 & 0 & 0.062 \\
\hline & US-37 N & 0.359 & 21740 & 4 & 1 & 1 & 0 & 1 & 0.387 \\
\hline \multirow[t]{6}{*}{ SR-450 W } & SR-450 W & 0.754 & 2350 & 2 & 0 & 0 & 1 & 0 & 0.042 \\
\hline & US-50 E & 0.018 & 5610 & 2 & 0 & 1 & 0 & 1 & 0.100 \\
\hline & SR-58 E & 0.001 & 600 & 2 & 0 & 0 & 0 & 0 & 0.011 \\
\hline & SR-158 W & 0.014 & 3500 & 2 & 0 & 0 & 0 & 0 & 0.062 \\
\hline & US-37 N & 0.202 & 21740 & 4 & 1 & 1 & 0 & 1 & 0.387 \\
\hline & US-37 S & 0.011 & 22370 & 4 & 0 & 0 & 0 & 1 & 0.398 \\
\hline \multirow[t]{6}{*}{ US-50 E } & US-50 E & 0.731 & 5610 & 2 & 0 & 0 & 1 & 1 & 0.100 \\
\hline & SR-58 E & 0.000 & 600 & 2 & 0 & 0 & 0 & 0 & 0.011 \\
\hline & SR-158 W & 0.019 & 3500 & 2 & 0 & 1 & 0 & 0 & 0.062 \\
\hline & US-37 N & 0.145 & 21740 & 4 & 1 & 0 & 0 & 1 & 0.387 \\
\hline & US-37 S & 0.100 & 22370 & 4 & 0 & 0 & 0 & 1 & 0.398 \\
\hline & SR-450 W & 0.004 & 2350 & 2 & 0 & 1 & 0 & 0 & 0.042 \\
\hline \multirow[t]{6}{*}{ SR-58 E } & SR-58 E & 0.870 & 600 & 2 & 0 & 0 & 1 & 0 & 0.011 \\
\hline & SR-158 W & 0.026 & 3500 & 2 & 0 & 1 & 0 & 0 & 0.062 \\
\hline & US-37 N & 0.101 & 21740 & 4 & 1 & 0 & 0 & 1 & 0.387 \\
\hline & US-37 S & 0.000 & 22370 & 4 & 0 & 0 & 0 & 1 & 0.398 \\
\hline & SR-450 W & 0.003 & 2350 & 2 & 0 & 0 & 0 & 0 & 0.042 \\
\hline & US-50 E & 0.000 & 5610 & 2 & 0 & 0 & 0 & 1 & 0.100 \\
\hline \multirow[t]{6}{*}{ SR-158 W } & SR-158 W & 0.486 & 3500 & 2 & 0 & 0 & 1 & 0 & 0.062 \\
\hline & US-37 N & 0.310 & 21740 & 4 & 1 & 0 & 0 & 1 & 0.387 \\
\hline & US-37 S & 0.136 & 22370 & 4 & 0 & 0 & 0 & 1 & 0.398 \\
\hline & SR-450 W & 0.009 & 2350 & 2 & 0 & 0 & 0 & 0 & 0.042 \\
\hline & US-50 E & 0.055 & 5610 & 2 & 0 & 0 & 0 & 1 & 0.100 \\
\hline & SR-58 E & 0.004 & 600 & 2 & 0 & 1 & 0 & 0 & 0.011 \\
\hline \multirow[t]{6}{*}{ US-37 N } & US-37 N & 0.488 & 21740 & 4 & 1 & 0 & 1 & 1 & 0.387 \\
\hline & US-37 S & 0.370 & 22370 & 4 & 0 & 1 & 0 & 1 & 0.398 \\
\hline & SR-450 W & 0.022 & 2350 & 2 & 0 & 0 & 0 & 0 & 0.042 \\
\hline & US-50 E & 0.068 & 5610 & 2 & 0 & 0 & 0 & 1 & 0.100 \\
\hline & SR-58 E & 0.003 & 600 & 2 & 0 & 0 & 0 & 0 & 0.011 \\
\hline & SR-158 W & 0.050 & 3500 & 2 & 0 & 0 & 0 & 0 & 0.062 \\
\hline
\end{tabular}


Table B.7- Elwood

\begin{tabular}{|l|l|l|r|r|r|r|r|r|l|}
\hline Origin & Destination & \multicolumn{1}{c|}{ Yij } & \multicolumn{1}{c|}{ ADTj } & NLj & NMCj & $\begin{array}{l}\text { RTEC } \\
\text { ONij }\end{array}$ & IEF & PA & $\begin{array}{l}\text { ADTjl } \\
\text { sum }\end{array}$ \\
\hline SR-13 N & SR-13 N & 0.441 & 3070 & 2 & 0 & 0 & 1 & 1 & 0.097 \\
\hline & SR-28 E & 0.023 & 6790 & 2 & 0 & 0 & 0 & 1 & 0.215 \\
\hline & SR-37 N & 0.000 & 3740 & 2 & 0 & 0 & 0 & 1 & 0.118 \\
\hline & SR-37 S & 0.502 & 13100 & 2 & 0 & 1 & 0 & 1 & 0.415 \\
\hline & SR-28 W & 0.034 & 4870 & 2 & 0 & 0 & 0 & 1 & 0.154 \\
\hline SR-28 E & SR-28 E & 0.492 & 6790 & 2 & 0 & 0 & 1 & 1 & 0.215 \\
\hline & SR-37 N & 0.115 & 3740 & 2 & 0 & 0 & 0 & 1 & 0.118 \\
\hline & SR-37 S & 0.179 & 13100 & 2 & 0 & 0 & 0 & 1 & 0.415 \\
\hline & SR-28 W & 0.204 & 4870 & 2 & 0 & 1 & 0 & 1 & 0.154 \\
\hline & SR-13 N & 0.011 & 3070 & 2 & 0 & 0 & 0 & 1 & 0.097 \\
\hline SR-37 N & SR-37 N & 0.200 & 3740 & 2 & 0 & 0 & 1 & 1 & 0.118 \\
\hline & SR-37 S & 0.547 & 13100 & 2 & 0 & 1 & 0 & 1 & 0.415 \\
\hline & SR-28 W & 0.043 & 4870 & 2 & 0 & 0 & 0 & 1 & 0.154 \\
\hline & SR-13 N & 0.000 & 3070 & 2 & 0 & 0 & 0 & 1 & 0.097 \\
\hline & SR-28 E & 0.210 & 6790 & 2 & 0 & 0 & 0 & 1 & 0.215 \\
\hline & SR-37 S & 0.621 & 13100 & 2 & 0 & 0 & 1 & 1 & 0.415 \\
\hline & SR-28 W & 0.013 & 4870 & 2 & 0 & 0 & 0 & 1 & 0.154 \\
\hline & SR-13 N & 0.118 & 3070 & 2 & 0 & 1 & 0 & 1 & 0.097 \\
\hline & SR-28 E & 0.092 & 6790 & 2 & 0 & 0 & 0 & 1 & 0.215 \\
\hline & SR-37 N & 0.156 & 3740 & 2 & 0 & 1 & 0 & 1 & 0.118 \\
\hline & SR-28 W & 0.627 & 4870 & 2 & 0 & 0 & 1 & 1 & 0.154 \\
\hline & SR-13 N & 0.021 & 3070 & 2 & 0 & 0 & 0 & 1 & 0.097 \\
\hline & SR-28 E & 0.284 & 6790 & 2 & 0 & 1 & 0 & 1 & 0.215 \\
\hline & SR-37 N & 0.033 & 3740 & 2 & 0 & 0 & 0 & 1 & 0.118 \\
\hline & SR-37 S & 0.034 & 13100 & 2 & 0 & 0 & 0 & 1 & 0.415 \\
\hline SR-28 W S
\end{tabular}

Table B.8- Tell City

\begin{tabular}{|l|l|c|r|r|r|r|r|r|l|}
\hline Origin & Destination & \multicolumn{1}{|c|}{ Yij } & \multicolumn{1}{c|}{ ADTj } & NLj & NMCj & $\begin{array}{l}\text { RTEC } \\
\text { ONij }\end{array}$ & IEF & PA & $\begin{array}{l}\text { ADTj/ } \\
\text { sum }\end{array}$ \\
\hline SR-66 N & SR-66 N & 0.698 & 11680 & 2 & 0 & 0 & 1 & 0 & 0.598 \\
\hline & SR-37 N & 0.114 & 6170 & 2 & 0 & 0 & 0 & 1 & 0.316 \\
\hline & SR-66 S & 0.189 & 1690 & 2 & 0 & 1 & 0 & 0 & 0.086 \\
\hline SR-37 N & SR-37 N & 0.783 & 6170 & 2 & 0 & 0 & 1 & 1 & 0.316 \\
\hline & SR-66 S & 0.000 & 1690 & 2 & 0 & 1 & 0 & 0 & 0.086 \\
\hline & SR-66 N & 0.217 & 11680 & 2 & 0 & 0 & 0 & 0 & 0.598 \\
\hline SR-66 S & SR-66 S & 0.827 & 1690 & 2 & 0 & 0 & 1 & 0 & 0.086 \\
\hline & SR-66 N & 0.173 & 11680 & 2 & 0 & 1 & 0 & 0 & 0.598 \\
\hline & SR-37 N & 0.000 & 6170 & 2 & 0 & 0 & 0 & 1 & 0.316 \\
\hline
\end{tabular}


Table B.9- Seymour

\begin{tabular}{|l|l|l|r|r|r|r|r|r|r|}
\hline Origin & Destination & \multicolumn{1}{c|}{ Yij } & \multicolumn{1}{c|}{ ADTj } & NLj & NMCj & $\begin{array}{l}\text { RTEC } \\
\text { ONij }\end{array}$ & IEF & PA & $\begin{array}{l}\text { ADTj/ } \\
\text { sum }\end{array}$ \\
\hline SR-11 S & SR-11 S & 0.976 & 4435 & 2 & 0 & 0 & 1 & 0 & 0.209 \\
\hline & US-50 W & 0.000 & 5775 & 4 & 0 & 0 & 0 & 1 & 0.272 \\
\hline & SR-258 W & 0.004 & 3840 & 2 & 0 & 0 & 0 & 0 & 0.181 \\
\hline & US-50 E & 0.012 & 5415 & 2 & 0 & 0 & 0 & 1 & 0.255 \\
\hline & SR-11 N & 0.008 & 1755 & 2 & 1 & 1 & 0 & 0 & 0.083 \\
\hline US-50 W & US-50 W & 0.654 & 5775 & 4 & 0 & 0 & 1 & 1 & 0.272 \\
\hline & SR-258 W & 0.053 & 3840 & 2 & 0 & 0 & 0 & 0 & 0.181 \\
\hline & US-50 E & 0.185 & 5415 & 2 & 0 & 1 & 0 & 1 & 0.255 \\
\hline & SR-11 N & 0.108 & 1755 & 2 & 1 & 0 & 0 & 0 & 0.083 \\
\hline & SR-11 S & 0.000 & 4435 & 2 & 0 & 0 & 0 & 0 & 0.209 \\
\hline SR-258 W & SR-258 W & 0.737 & 3840 & 2 & 0 & 0 & 1 & 0 & 0.181 \\
\hline & US-50 E & 0.082 & 5415 & 2 & 0 & 0 & 0 & 1 & 0.255 \\
\hline & SR-11 N & 0.097 & 1755 & 2 & 1 & 0 & 0 & 0 & 0.083 \\
\hline & SR-11 S & 0.005 & 4435 & 2 & 0 & 0 & 0 & 0 & 0.209 \\
\hline & US-50 W & 0.080 & 5775 & 4 & 0 & 0 & 0 & 1 & 0.272 \\
\hline & US-50 E & 0.735 & 5415 & 2 & 0 & 0 & 1 & 1 & 0.255 \\
\hline US-50 E & SR-11 N & 0.000 & 1755 & 2 & 1 & 0 & 0 & 0 & 0.083 \\
\hline & SR-11 S & 0.010 & 4435 & 2 & 0 & 0 & 0 & 0 & 0.209 \\
\hline & US-50 W & 0.197 & 5775 & 4 & 0 & 1 & 0 & 1 & 0.272 \\
\hline & SR-258 W & 0.058 & 3840 & 2 & 0 & 0 & 0 & 0 & 0.181 \\
\hline & SR-11 N & 0.413 & 1755 & 2 & 1 & 0 & 1 & 0 & 0.083 \\
\hline & SR-11 S & 0.021 & 4435 & 2 & 0 & 1 & 0 & 0 & 0.209 \\
\hline & US-50 W & 0.354 & 5775 & 4 & 0 & 0 & 0 & 1 & 0.272 \\
\hline SR-11 N & SR8 W & 0.211 & 3840 & 2 & 0 & 0 & 0 & 0 & 0.181 \\
\hline & US-50 E & 0.000 & 5415 & 2 & 0 & 0 & 0 & 1 & 0.255 \\
\hline
\end{tabular}


Table B.10- Brazil

\begin{tabular}{|l|l|r|r|r|r|r|r|r|r|}
\hline Origin & Destination & \multicolumn{1}{|c|}{ Yij $^{1}$} & \multicolumn{1}{c|}{ ADTj } & \multicolumn{1}{l|}{ NLj } & NMCj & $\begin{array}{l}\text { RTEC } \\
\text { ONij }\end{array}$ & \multicolumn{1}{l|}{ IEF } & PA & $\begin{array}{l}\text { ADTj/ } \\
\text { sum }\end{array}$ \\
\hline SR-340 W & SR-340 W & 0.812 & 9100 & 2 & 1 & 0 & 1 & 0 & 0.219 \\
\hline & SR-59 N & 0.019 & 5140 & 2 & 0 & 0 & 0 & 1 & 0.124 \\
\hline & US-40 E & 0.092 & 13640 & 4 & 0 & 1 & 0 & 1 & 0.328 \\
\hline & US-40 W & 0.000 & 5010 & 4 & 1 & 0 & 0 & 1 & 0.121 \\
\hline & SR-59 S & 0.076 & 8650 & 2 & 0 & 0 & 0 & 1 & 0.208 \\
\hline SR-59 N & SR-59 N & 0.659 & 5140 & 2 & 0 & 0 & 1 & 1 & 0.124 \\
\hline & US-40 E & 0.054 & 13640 & 4 & 0 & 0 & 0 & 1 & 0.328 \\
\hline & US-40 W & 0.108 & 5010 & 4 & 1 & 0 & 0 & 1 & 0.121 \\
\hline & SR-59 S & 0.160 & 8650 & 2 & 0 & 1 & 0 & 1 & 0.208 \\
\hline & SR-340 W & 0.019 & 9100 & 2 & 1 & 0 & 0 & 0 & 0.219 \\
\hline US-40 E & US-40 E & 0.803 & 13640 & 4 & 0 & 0 & 1 & 1 & 0.328 \\
\hline & US-40 W & 0.120 & 5010 & 4 & 1 & 1 & 0 & 1 & 0.121 \\
\hline & SR-59 S & 0.022 & 8650 & 2 & 0 & 0 & 0 & 1 & 0.208 \\
\hline & SR-340 W & 0.034 & 9100 & 2 & 1 & 0 & 0 & 0 & 0.219 \\
\hline & SR-59 N & 0.021 & 5140 & 2 & 0 & 0 & 0 & 1 & 0.124 \\
\hline US-40 W W & US-40 W & 0.547 & 5010 & 4 & 1 & 0 & 1 & 1 & 0.121 \\
\hline & SR-59 S & 0.015 & 8650 & 2 & 0 & 0 & 0 & 1 & 0.208 \\
\hline & SR-340 W & 0.000 & 9100 & 2 & 1 & 0 & 0 & 0 & 0.219 \\
\hline & SR-59 N & 0.111 & 5140 & 2 & 0 & 0 & 0 & 1 & 0.124 \\
\hline & US-40 E & 0.327 & 13640 & 4 & 0 & 1 & 0 & 1 & 0.328 \\
\hline & SR-59 S & 0.817 & 8650 & 2 & 0 & 0 & 1 & 1 & 0.208 \\
\hline SR-59 S & SR-340 W & 0.044 & 9100 & 2 & 1 & 0 & 0 & 0 & 0.219 \\
\hline & SR-59 N & 0.095 & 5140 & 2 & 0 & 1 & 0 & 1 & 0.124 \\
\hline & US-40 E & 0.035 & 13640 & 4 & 0 & 0 & 0 & 1 & 0.328 \\
\hline & US-40 W & 0.009 & 5010 & 4 & 1 & 0 & 0 & 1 & 0.121 \\
\hline
\end{tabular}

Table B.11- Peru

\begin{tabular}{|l|l|c|r|r|r|r|r|r|l|}
\hline Origin & Destination & \multicolumn{1}{|c|}{ Yij } & \multicolumn{1}{c|}{ ADTj } & NLj & NMCj & $\begin{array}{l}\text { RTEC } \\
\text { ONij }\end{array}$ & IEF & PA & $\begin{array}{l}\text { ADTj/ } \\
\text { sum }\end{array}$ \\
\hline SR-124 E & SR-124 E & 0.820 & 1680 & 2 & 0 & 0 & 1 & 0 & 0.223 \\
\hline & SR-19 N & 0.148 & 3060 & 2 & 0 & 0 & 0 & 0 & 0.406 \\
\hline & SR-19 S & 0.032 & 2800 & 2 & 0 & 0 & 0 & 0 & 0.371 \\
\hline SR-19 N & SR-19 N & 0.843 & 3060 & 2 & 0 & 0 & 1 & 0 & 0.406 \\
\hline & SR-19 S & 0.078 & 2800 & 2 & 0 & 1 & 0 & 0 & 0.371 \\
\hline & SR-124 E & 0.079 & 1680 & 2 & 0 & 0 & 0 & 0 & 0.223 \\
\hline SR-19 S & SR-19 S & 0.896 & 2800 & 2 & 0 & 0 & 1 & 0 & 0.371 \\
\hline & SR-124 E & 0.019 & 1680 & 2 & 0 & 0 & 0 & 0 & 0.223 \\
\hline & SR-19 N & 0.086 & 3060 & 2 & 0 & 1 & 0 & 0 & 0.406 \\
\hline
\end{tabular}


Table B.12- Shelbyville

\begin{tabular}{|l|l|c|r|r|r|r|r|r|l|}
\hline Origin & Destination & \multicolumn{1}{c|}{ Yij } & \multicolumn{1}{c|}{ ADTj } & NLj & NMCj & $\begin{array}{l}\text { RTEC } \\
\text { ONij }\end{array}$ & IEF & PA & $\begin{array}{l}\text { ADTj/ } \\
\text { sum }\end{array}$ \\
\hline SR-44 W & SR-44 W & 0.572 & 4090 & 2 & 0 & 0 & 1 & 1 & 0.180 \\
\hline & SR-9 S & 0.013 & 2625 & 2 & 0 & 0 & 0 & 1 & 0.116 \\
\hline & SR-44 E & 0.261 & 7350 & 2 & 0 & 1 & 0 & 1 & 0.324 \\
\hline & SR-9 N & 0.154 & 8610 & 4 & 0 & 0 & 0 & 1 & 0.380 \\
\hline SR-9 S & SR-9 S & 0.531 & 2625 & 2 & 0 & 0 & 1 & 1 & 0.116 \\
\hline & SR-44 E & 0.082 & 7350 & 2 & 0 & 0 & 0 & 1 & 0.324 \\
\hline & SR-9 N & 0.365 & 8610 & 4 & 0 & 1 & 0 & 1 & 0.380 \\
\hline & SR-44 W & 0.021 & 4090 & 2 & 0 & 0 & 0 & 1 & 0.180 \\
\hline SR-44 E & SR-44 E & 0.794 & 7350 & 2 & 0 & 0 & 1 & 1 & 0.324 \\
\hline & SR-9 N & 0.031 & 8610 & 4 & 0 & 0 & 0 & 1 & 0.380 \\
\hline & SR-44 W & 0.145 & 4090 & 2 & 0 & 1 & 0 & 1 & 0.180 \\
\hline & SR-9 S & 0.029 & 2625 & 2 & 0 & 0 & 0 & 1 & 0.116 \\
\hline SR-9 N & SR-9 N & 0.789 & 8610 & 4 & 0 & 0 & 1 & 1 & 0.380 \\
\hline & SR-44 W & 0.073 & 4090 & 2 & 0 & 0 & 0 & 1 & 0.180 \\
\hline & SR-9 S & 0.111 & 2625 & 2 & 0 & 1 & 0 & 1 & 0.116 \\
\hline & SR-44 E & 0.027 & 7350 & 2 & 0 & 0 & 0 & 1 & 0.324 \\
\hline
\end{tabular}

Table B.13- Franklin

\begin{tabular}{|l|l|l|r|r|r|r|r|r|c|}
\hline Origin & Destination & \multicolumn{1}{c|}{ Yij } & \multicolumn{1}{c|}{ ADTj } & NLj & NMCj & $\begin{array}{l}\text { RTEC } \\
\text { ONij }\end{array}$ & IEF & PA & $\begin{array}{l}\text { ADTj/ } \\
\text { sum }\end{array}$ \\
\hline SR-44 E & SR-44 E & 0.896 & 7965 & 2 & 0 & 0 & 1 & 1 & 0.231 \\
\hline & SR-44 W & 0.066 & 5760 & 2 & 0 & 1 & 0 & 1 & 0.167 \\
\hline & US-31 S & 0.038 & 5720 & 4 & 0 & 0 & 0 & 1 & 0.166 \\
\hline & US-31 N & 0.000 & 13900 & 4 & 1 & 0 & 0 & 1 & 0.404 \\
\hline SR-44 W & SR-44 W & 0.787 & 5760 & 2 & 0 & 0 & 1 & 1 & 0.167 \\
\hline & US-31 S & 0.108 & 5720 & 4 & 0 & 0 & 0 & 1 & 0.166 \\
\hline & US-31 N & 0.014 & 13900 & 4 & 1 & 0 & 0 & 1 & 0.404 \\
\hline & SR-44 E & 0.091 & 7965 & 2 & 0 & 1 & 0 & 1 & 0.231 \\
\hline US-31 S & US-31 S & 0.777 & 5720 & 4 & 0 & 0 & 1 & 1 & 0.166 \\
\hline & US-31 N & 0.062 & 13900 & 4 & 1 & 1 & 0 & 1 & 0.404 \\
\hline & SR-44 E & 0.053 & 7965 & 2 & 0 & 0 & 0 & 1 & 0.231 \\
\hline & SR-44 W & 0.108 & 5760 & 2 & 0 & 0 & 0 & 1 & 0.167 \\
\hline US-31 N & US-31 N & 0.969 & 13900 & 4 & 1 & 0 & 1 & 1 & 0.404 \\
\hline & SR-44 E & 0.000 & 7965 & 2 & 0 & 0 & 0 & 1 & 0.231 \\
\hline & SR-44 W & 0.006 & 5760 & 2 & 0 & 0 & 0 & 1 & 0.167 \\
\hline & US-31 S & 0.025 & 5720 & 4 & 0 & 1 & 0 & 1 & 0.166 \\
\hline
\end{tabular}


Table B.14- Vincennes

\begin{tabular}{|c|c|c|c|c|c|c|c|c|c|}
\hline Origin & Destination & $Y_{i j}$ & ADTj & $\mathrm{NLj}$ & $\mathrm{NMCj}$ & $\begin{array}{l}\text { RTEC } \\
\text { ONij }\end{array}$ & IEF & PA & $\begin{array}{l}\text { ADTj/ } \\
\text { sum }\end{array}$ \\
\hline \multirow[t]{6}{*}{ SR-67 N } & SR-67 N & 0.640 & 7280 & 2 & 0 & 0 & 1 & 0 & 0.129 \\
\hline & US-50 W & 0.290 & 5310 & 4 & 0 & 0 & 0 & 1 & 0.094 \\
\hline & US-50 E & 0.000 & 7360 & 4 & 0 & 0 & 0 & 1 & 0.130 \\
\hline & US-41 N & 0.002 & 14540 & 4 & 0 & 0 & 0 & 1 & 0.257 \\
\hline & US-41 S & 0.068 & 14590 & 4 & 0 & 0 & 0 & 1 & 0.258 \\
\hline & SR-33 W & 0.000 & 6600 & 2 & 0 & 0 & 0 & 0 & 0.117 \\
\hline \multirow[t]{6}{*}{ US-50 W } & US-50 W & 0.138 & 5310 & 4 & 0 & 0 & 1 & 1 & 0.094 \\
\hline & US-50 E & 0.148 & 7360 & 4 & 0 & 1 & 0 & 1 & 0.130 \\
\hline & US-41 N & 0.306 & 14540 & 4 & 0 & 0 & 0 & 1 & 0.257 \\
\hline & US-41 S & 0.010 & 14590 & 4 & 0 & 0 & 0 & 1 & 0.258 \\
\hline & SR-33 W & 0.000 & 6600 & 2 & 0 & 0 & 0 & 0 & 0.117 \\
\hline & SR-67 N & 0.398 & 7280 & 2 & 0 & 0 & 0 & 0 & 0.129 \\
\hline \multirow[t]{6}{*}{ US-50 E } & US-50 E & 0.878 & 7360 & 4 & 0 & 0 & 1 & 1 & 0.130 \\
\hline & US-41 N & 0.002 & 14540 & 4 & 0 & 0 & 0 & 1 & 0.257 \\
\hline & US-41 S & 0.002 & 14590 & 4 & 0 & 0 & 0 & 1 & 0.258 \\
\hline & SR-33 W & 0.000 & 6600 & 2 & 0 & 0 & 0 & 0 & 0.117 \\
\hline & SR-67 N & 0.000 & 7280 & 2 & 0 & 0 & 0 & 0 & 0.129 \\
\hline & US-50 W & 0.118 & 5310 & 4 & 1 & 0 & 0 & 1 & 0.094 \\
\hline \multirow[t]{6}{*}{ US-41 N } & US-41 N & 0.496 & 14540 & 4 & 0 & 0 & 1 & 1 & 0.257 \\
\hline & US-41 S & 0.391 & 14590 & 4 & 0 & 1 & 0 & 1 & 0.258 \\
\hline & SR-33 W & 0.000 & 6600 & 2 & 0 & 0 & 0 & 0 & 0.117 \\
\hline & SR-67 N & 0.001 & 7280 & 2 & 0 & 0 & 0 & 0 & 0.129 \\
\hline & US-50 W & 0.110 & 5310 & 4 & 0 & 0 & 0 & 1 & 0.094 \\
\hline & US-50 E & 0.001 & 7360 & 4 & 0 & 0 & 0 & 1 & 0.130 \\
\hline \multirow[t]{6}{*}{ US-41 S } & US-41 S & 0.541 & 14590 & 4 & 0 & 0 & 1 & 1 & 0.258 \\
\hline & SR-33 W & 0.030 & 6600 & 2 & 0 & 0 & 0 & 0 & 0.117 \\
\hline & SR-67 N & 0.034 & 7280 & 2 & 0 & 0 & 0 & 0 & 0.129 \\
\hline & US-50 W & 0.000 & 5310 & 4 & 0 & 0 & 0 & 1 & 0.094 \\
\hline & US-50 E & 0.006 & 7360 & 4 & 0 & 0 & 0 & 1 & 0.130 \\
\hline & US-41 N & 0.389 & 14540 & 4 & 0 & 1 & 0 & 1 & 0.257 \\
\hline \multirow[t]{6}{*}{ SR-33 W } & SR-33 W & 0.934 & 6600 & 2 & 0 & 0 & 1 & 0 & 0.117 \\
\hline & SR-67 N & 0.000 & 7280 & 2 & 0 & 0 & 0 & 0 & 0.129 \\
\hline & US-50 W & 0.000 & 5310 & 4 & 0 & 0 & 0 & 1 & 0.094 \\
\hline & US-50 E & 0.000 & 7360 & 4 & 0 & 0 & 0 & 1 & 0.130 \\
\hline & US-41 N & 0.000 & 14540 & 4 & 0 & 0 & 0 & 1 & 0.257 \\
\hline & US-41 S & 0.066 & 14590 & 4 & 0 & 0 & 0 & 1 & 0.258 \\
\hline
\end{tabular}


Table B.15- Kendallville

\begin{tabular}{|l|l|r|r|r|r|r|r|r|r|}
\hline Origin & Destination & \multicolumn{1}{c|}{ Yij } & \multicolumn{1}{c|}{ ADTj } & NLj & NMCj & $\begin{array}{l}\text { RTEC } \\
\text { ONij }\end{array}$ & IEF & \multicolumn{1}{l|}{ PA } & $\begin{array}{l}\text { ADTj/ } \\
\text { sum }\end{array}$ \\
\hline SR-3 S & SR-3 S & 0.585 & 15360 & 4 & 0 & 0 & 1 & 1 & 0.315 \\
\hline & Angling Rd & 0.025 & 4236 & 2 & 0 & 0 & 0 & 0 & 0.087 \\
\hline & US-6 W & 0.334 & 13760 & 2 & 0 & 0 & 0 & 1 & 0.282 \\
\hline & SR-3 N & 0.055 & 7040 & 2 & 0 & 1 & 0 & 0 & 0.144 \\
\hline & US-6 E & 0.000 & 8430 & 2 & 0 & 0 & 0 & 1 & 0.173 \\
\hline Angling Rd & Angling Rd & 0.869 & 4236 & 2 & 0 & 0 & 1 & 0 & 0.087 \\
\hline & US-6 W & 0.017 & 13760 & 2 & 0 & 0 & 0 & 1 & 0.282 \\
\hline & SR-3 N & 0.000 & 7040 & 2 & 0 & 0 & 0 & 0 & 0.144 \\
\hline & US-6 E & 0.072 & 8430 & 2 & 0 & 1 & 0 & 1 & 0.173 \\
\hline & SR-3 S & 0.042 & 15360 & 4 & 0 & 1 & 0 & 1 & 0.315 \\
\hline US-6 W & US-6 W & 0.770 & 13760 & 2 & 0 & 0 & 1 & 1 & 0.282 \\
\hline & SR-3 N & 0.022 & 7040 & 2 & 0 & 0 & 0 & 0 & 0.144 \\
\hline & US-6 E & 0.065 & 8430 & 2 & 0 & 1 & 0 & 1 & 0.173 \\
\hline & SR-3 S & 0.139 & 15360 & 4 & 0 & 0 & 0 & 1 & 0.315 \\
\hline & Angling Rd & 0.004 & 4236 & 2 & 0 & 0 & 0 & 0 & 0.087 \\
\hline & SR-3 N & 0.754 & 7040 & 2 & 0 & 0 & 1 & 0 & 0.144 \\
\hline SR-3 N & US-6 E & 0.000 & 8430 & 2 & 0 & 0 & 0 & 1 & 0.173 \\
\hline & SR-3 S & 0.121 & 15360 & 4 & 0 & 1 & 0 & 1 & 0.315 \\
\hline & Angling Rd & 0.000 & 4236 & 2 & 0 & 0 & 0 & 0 & 0.087 \\
\hline & US-6 W & 0.124 & 13760 & 2 & 0 & 0 & 0 & 1 & 0.282 \\
\hline & US-6 E & 0.900 & 8430 & 2 & 0 & 0 & 1 & 1 & 0.173 \\
\hline & SR-3 S & 0.000 & 15360 & 4 & 0 & 0 & 0 & 1 & 0.315 \\
\hline & Angling Rd & 0.020 & 4236 & 2 & 0 & 0 & 0 & 0 & 0.087 \\
\hline US-6 E & US-6 W & 0.080 & 13760 & 2 & 0 & 1 & 0 & 1 & 0.282 \\
\hline & SR-3 N & 0.000 & 7040 & 2 & 0 & 0 & 0 & 0 & 0.144 \\
\hline
\end{tabular}




\section{$\underline{\text { Appendix C }}$}

LIMDEP Input Code is presented in this section

\section{Logit Model with All Parameters}

read; nvar $=13 ;$ nobs $=262 ;$ file $=H: \backslash O D \backslash$ model $\backslash$ input 5. txt $\$$

nlogit;

lhs $=\mathrm{x} 1, \mathrm{x} 2$;

choices=option1, option2, option3, option4, option5, option6, option7, option8 ; rhs=one, $\mathrm{x} 4, \mathrm{x} 7, \mathrm{x} 10, \mathrm{x} 9, \mathrm{x} 11, \mathrm{x} 12 \$$

\section{Logit Model with Selected Parameters}

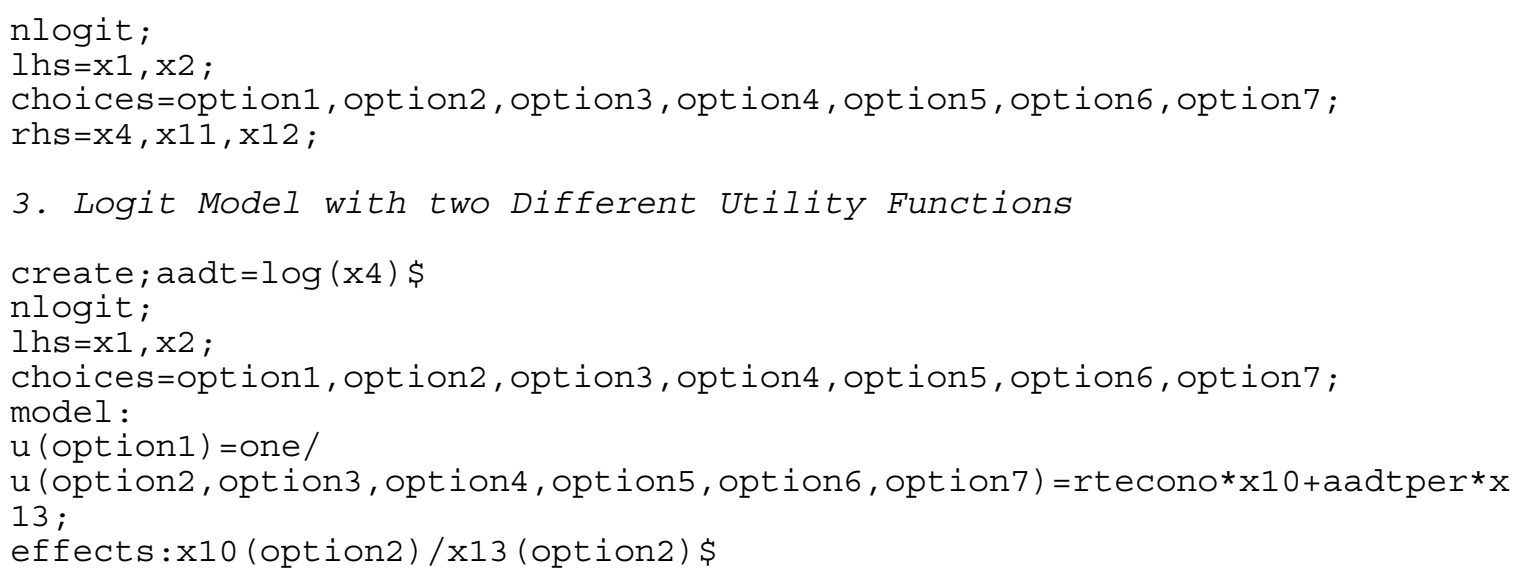




\section{$\underline{\text { Appendix D }}$}

Table D.1- Parameters used to estimate through trips for Greenfield

\begin{tabular}{|l|l|r|r|r|r|}
\hline Origin & Destination & ADTj & RTECONij & IEF & ADTj/sum \\
\hline SR-9 N & SR-9 N & 10007 & 0 & 1 & 0.1534 \\
\hline & I-70 W ramp & 16860 & 0 & 0 & 0.2584 \\
\hline & US-40 W & 14446 & 0 & 0 & 0.2214 \\
\hline & SR-9 S & 8336 & 1 & 0 & 0.1278 \\
\hline & US-40 E & 9843 & 0 & 0 & 0.1509 \\
\hline & I-70 E ramp & 5758 & 0 & 0 & 0.0882 \\
\hline I-70 W ramp & I-70 W ramp & 16860 & 0 & 1 & 0.2584 \\
\hline & US-40 W & 14446 & 0 & 0 & 0.2214 \\
\hline & SR-9 S & 8336 & 1 & 0 & 0.1278 \\
\hline & US-40 E & 9843 & 0 & 0 & 0.1509 \\
\hline & I-70 E ramp & 5758 & 0 & 0 & 0.0882 \\
\hline & SR-9 N & 10007 & 1 & 0 & 0.1534 \\
\hline & US-40 W & 14446 & 0 & 1 & 0.2214 \\
\hline & SR-9 S & 8336 & 0 & 0 & 0.1278 \\
\hline & US-40 E & 9843 & 1 & 0 & 0.1509 \\
\hline & I-70 E ramp & 5758 & 0 & 0 & 0.0882 \\
\hline & SR-9 N & 10007 & 0 & 0 & 0.1534 \\
\hline & I-70 W ramp & 16860 & 0 & 0 & 0.2584 \\
\hline & SR-9 S & 8336 & 0 & 1 & 0.1278 \\
\hline & US-40 E & 9843 & 0 & 0 & 0.1509 \\
\hline & I-70 E ramp & 5758 & 0 & 0 & 0.0882 \\
\hline & SR-9 N & 10007 & 1 & 0 & 0.1534 \\
\hline & I-70 W ramp & 16860 & 0 & 0 & 0.2584 \\
\hline SR-9 S & US-40 W & 14446 & 0 & 0 & 0.2214 \\
\hline & US-40 E & 9843 & 0 & 1 & 0.1509 \\
\hline & I-70 E ramp & 5758 & 0 & 0 & 0.0882 \\
\hline & SR-9 N & 10007 & 0 & 0 & 0.1534 \\
\hline & I-70 W ramp & 16860 & 0 & 0 & 0.2584 \\
\hline & US-40 W & 14446 & 1 & 0 & 0.2214 \\
\hline & SR-9 S & 8336 & 0 & 0 & 0.1278 \\
\hline & I-70 E ramp & 5758 & 1 & 1 & 0.0882 \\
\hline & SR-9 N & 10007 & 1 & 0 & 0.1534 \\
\hline & I-70 W ramp & 16860 & 0 & 0 & 0.2584 \\
\hline & US-40 W & 14446 & 0 & 0 & 0.2214 \\
\hline & SR-9 S & 8336 & 0 & 0 & 0.1278 \\
\hline & US-40 E & 9843 & 0 & 0 & 0.1509 \\
\hline & & & & \\
\hline & & & 0 & 0 & 0 \\
\hline
\end{tabular}




\section{$\underline{\text { Appendix E }}$}

Table E.1- Parameters used to estimate through trips for LaPorte

\begin{tabular}{|c|c|c|c|c|c|}
\hline Origin & Destination & ADTj & RTECONij & IEF & ADTj/sum \\
\hline \multirow{8}{*}{ Johnson } & Johnson & 8252 & 0 & 1 & 0.1255 \\
\hline & US35 N & 10376 & 0 & 0 & 0.1578 \\
\hline & SR39 N & 7030 & 0 & 0 & 0.1069 \\
\hline & SR2 W & 11826 & 0 & 0 & 0.1799 \\
\hline & SR4 E & 5898 & 0 & 0 & 0.0897 \\
\hline & US35 S & 10534 & 0 & 0 & 0.1602 \\
\hline & SR39 S & 3180 & 0 & 0 & 0.0484 \\
\hline & SR2E & 8646 & 0 & 0 & 0.1315 \\
\hline \multirow[t]{8}{*}{ US35 N } & US35 N & 10376 & 0 & 1 & 0.1578 \\
\hline & SR39 N & 7030 & 0 & 0 & 0.1069 \\
\hline & SR2 W & 11826 & 0 & 0 & 0.1799 \\
\hline & SR4 E & 5898 & 0 & 0 & 0.0897 \\
\hline & US35 S & 10534 & 1 & 0 & 0.1602 \\
\hline & SR39 S & 3180 & 0 & 0 & 0.0484 \\
\hline & SR2E & 8646 & 0 & 0 & 0.1315 \\
\hline & Johnson & 8252 & 0 & 0 & 0.1255 \\
\hline \multirow[t]{8}{*}{ SR39 N } & SR39 N & 7030 & 0 & 1 & 0.1069 \\
\hline & SR2 W & 11826 & 0 & 0 & 0.1799 \\
\hline & SR4 E & 5898 & 0 & 0 & 0.0897 \\
\hline & US35 S & 10534 & 0 & 0 & 0.1602 \\
\hline & SR39 S & 3180 & 1 & 0 & 0.0484 \\
\hline & SR2E & 8646 & 0 & 0 & 0.1315 \\
\hline & Johnson & 8252 & 0 & 0 & 0.1255 \\
\hline & US35 N & 10376 & 0 & 0 & 0.1578 \\
\hline \multirow[t]{8}{*}{ SR2 W } & SR2 W & 11826 & 0 & 1 & 0.1799 \\
\hline & SR4 E & 5898 & 0 & 0 & 0.0897 \\
\hline & US35 S & 10534 & 0 & 0 & 0.1602 \\
\hline & SR39 S & 3180 & 0 & 0 & 0.0484 \\
\hline & SR2E & 8646 & 1 & 0 & 0.1315 \\
\hline & Johnson & 8252 & 0 & 0 & 0.1255 \\
\hline & US35 N & 10376 & 0 & 0 & 0.1578 \\
\hline & SR39 N & 7030 & 0 & 0 & 0.1069 \\
\hline \multirow[t]{4}{*}{ SR4 E } & SR4 E & 5898 & 0 & 1 & 0.0897 \\
\hline & US35 S & 10534 & 0 & 0 & 0.1602 \\
\hline & SR39 S & 3180 & 0 & 0 & 0.0484 \\
\hline & SR2E & 8646 & 0 & 0 & 0.1315 \\
\hline
\end{tabular}




\begin{tabular}{|r|l|r|r|r|r|}
\hline & Johnson & 8252 & 0 & 0 & 0.1255 \\
\hline & US35 N & 10376 & 0 & 0 & 0.1578 \\
\hline & SR39 N & 7030 & 0 & 0 & 0.1069 \\
\hline & SR2 W & 11826 & 0 & 0 & 0.1799 \\
\hline US35 S & US35 S & 10534 & 0 & 1 & 0.1602 \\
\hline & SR39 S & 3180 & 0 & 0 & 0.0484 \\
\hline & SR2E & 8646 & 0 & 0 & 0.1315 \\
\hline & Johnson & 8252 & 0 & 0 & 0.1255 \\
\hline & US35 N & 10376 & 1 & 0 & 0.1578 \\
\hline & SR39 N & 7030 & 0 & 0 & 0.1069 \\
\hline & SR2 W & 11826 & 0 & 0 & 0.1799 \\
\hline & SR4 E & 5898 & 0 & 0 & 0.0897 \\
\hline SR39 S & SR39 S & 3180 & 0 & 1 & 0.0484 \\
\hline & SR2E & 8646 & 0 & 0 & 0.1315 \\
\hline & Johnson & 8252 & 0 & 0 & 0.1255 \\
\hline & US35 N & 10376 & 0 & 0 & 0.1578 \\
\hline & SR39 N & 7030 & 1 & 0 & 0.1069 \\
\hline & SR2 W & 11826 & 0 & 0 & 0.1799 \\
\hline & SR4 E & 5898 & 0 & 0 & 0.0897 \\
\hline & US35 S & 10534 & 0 & 0 & 0.1602 \\
\hline & SR2E & 8646 & 0 & 1 & 0.1315 \\
\hline & Johnson & 8252 & 0 & 0 & 0.1255 \\
\hline & US35 N & 10376 & 0 & 0 & 0.1578 \\
\hline & SR39 N & 7030 & 0 & 0 & 0.1069 \\
\hline & SR2 W & 11826 & 1 & 0 & 0.1799 \\
\hline & SR4 E & 5898 & 0 & 0 & 0.0897 \\
\hline & US35 S & 10534 & 0 & 0 & 0.1602 \\
\hline & SR39 S & 3180 & 0 & 0 & 0.0484 \\
\hline & & & & & \\
\hline & & 0 & 0 & 0 & 0 \\
\hline
\end{tabular}




\section{Through Route Estimation By Logit}

\section{(TREBL)}

Users Guide

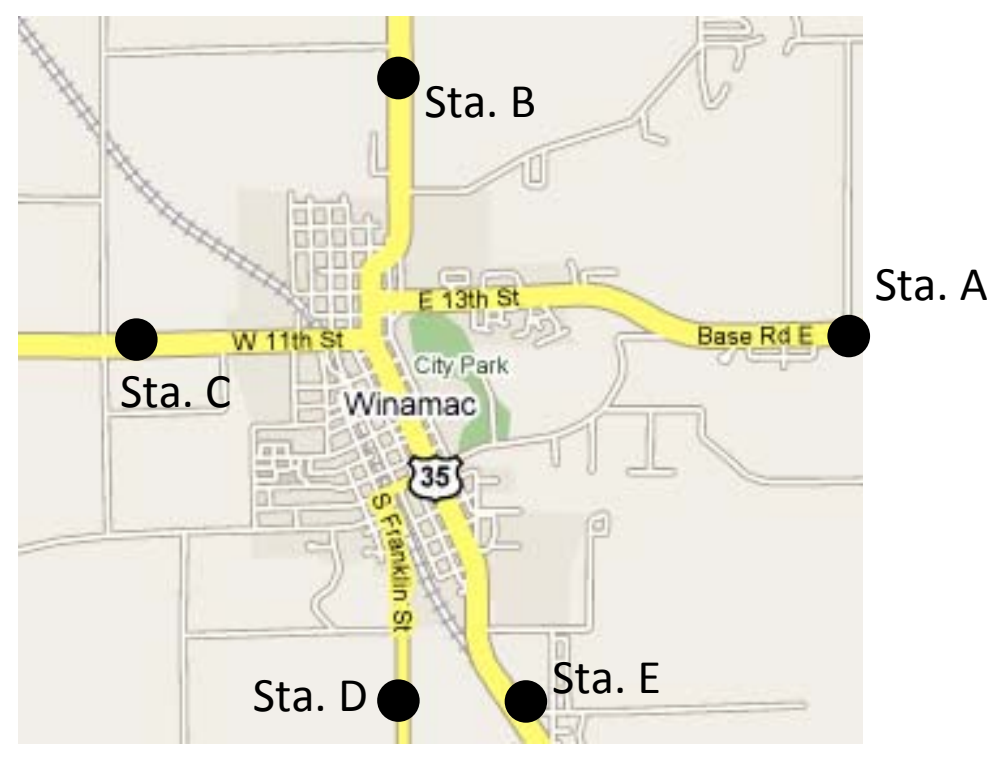

Figure 1. Five external stations at the boundary of a study area

A guide to using the worksheet-based TREBL method to estimate the number of through trips and internal-external trips for small and medium cities in Indiana

Jon D. Fricker and Mary Martchouk

Purdue University

June 2009 


\section{When to use TREBL}

When you need to know what happens to vehicles that enter a study area at any external station (such as points $A, B, C, D$, and $E$ in the map on the cover of this guide). How many of those entering vehicles leave the study area via another external station? How many of those entering vehicles have destinations within the study area? Likewise, how many vehicle trips starting within the study area cross the boundaries of the study area at any given external station?

These questions arise, for example, when a bypass highway is being considered for a city. Are there a sufficient number of through trips to justify the construction of a bypass route that takes those vehicles off city streets and permits them to go around the city?

License plate surveys have been used to attempt to match vehicle observations at two external stations. This method has the potential for good results, but it can be expensive, tedious, and susceptible to errors.

Normally, the best way to estimate patterns of trips through a city is to run the subarea focus feature of the Indiana State Travel Demand Model (ISTDM). This allows the analyst to capture a city's approximate through trips pattern in the context of the network that surrounds it. However, running the ISTDM requires knowledge of the software, access to the extensive statewide databases, and time - a single run of the ISTDM takes approximately 2 hours. In addition, the relatively coarse nature of the ISTDM network and O-D matrix sometimes fails to capture local trip patterns.

TREBL has been developed to act as a substitute for the subarea focus feature of the ISTDM. Tests have shown that TREBL produces good approximations to subarea focus results. TREBL can be used as a screening tool to determine whether more detailed methods to estimate an $\mathrm{O}$ D matrix for through trips are justified.

\section{What does TREBL give you?}

An estimate of through trip patterns can be summarized as an origin-destination (O-D) matrix, as shown in Table 1.

In Table 1, 100 vehicles entered at External Station A and left via Station B, 200 vehicles entered at Station $A$ and left via Station C, etc.

\begin{tabular}{|c|c|c|c|c|c|}
\hline \multicolumn{5}{|c|}{ Table 1. Example of a through trip table } \\
\hline & \multicolumn{5}{|c|}{ Destinations } \\
\hline Origin & A & B & C & D & E \\
\hline A & 1000 & 100 & 200 & 15 & 500 \\
\hline B & 100 & 1500 & 250 & 50 & 100 \\
\hline C & 200 & 250 & 900 & 70 & 0 \\
\hline D & 15 & 50 & 70 & 600 & 80 \\
\hline E & 500 & 100 & 0 & 80 & 1200 \\
\hline
\end{tabular}


Because a trip entering at Station A and leaving via Station A makes little sense, the highlighted diagonal cells in the O-D matrix are used to show how many vehicles were making trips that had one end within the study area and one end outside the study area. These are called internal-external (IE) trips when the trips start within the study area and external-internal (EI) trips when the trip starts outside the study area. In Table 1, 1000 of the vehicles observed at External Station A had one trip end within the study area. On a daily basis, this means $500 \mathrm{EI}$ trips and 500 IE trips. Likewise, 1500 of the vehicles observed at Station B had one trip end within the study area. The entries in the diagonal cells are two-way volumes. The other (offthe-diagonal) entries are directed from origin (entry point) station to destination (exit point) station.

\section{How to use TREBL}

Open the Excel file TREBL.xls. The workbook has ten worksheets, each with a tab. (See Figure 3.) The first two worksheet tabs are "INPUT" and "OUTPUT". The other eight worksheets (" 3 stations", ..., "10 stations") are workspaces that the user can look at, if he/she wishes, but should not modify. The INPUT worksheet contains the steps listed below. In our example, we will use LaPorte (Figure 2) as our study area.

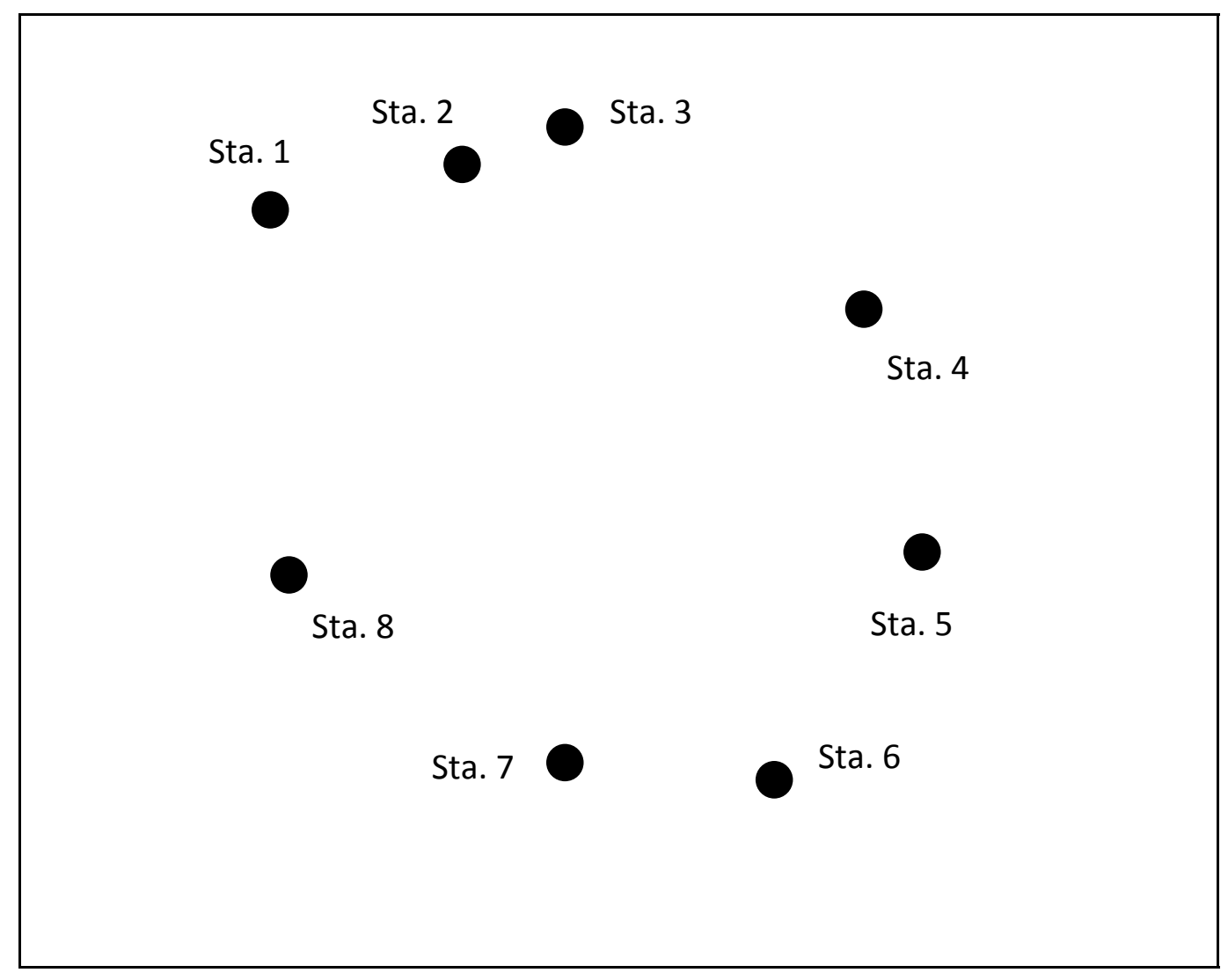

Figure 2. La Porte Study Area 


\section{Step 1: Enter the number of external stations in Cell A3.}

TREBL is designed to handle study areas with 3-10 external stations. LaPorte has 8 external stations. See Table 2.

Table 2. External Stations for LaPorte

\begin{tabular}{|c|l|}
\hline Station number & Location \\
\hline 1 & Johnson Rd. west of Toll Rd. \\
\hline 2 & US-35N south of Toll Rd. \\
\hline 3 & SR-39N south of Toll Rd. \\
\hline 4 & SR-2E west of Lofgren Rd. \\
\hline 5 & SR-4E west of CR-200 E \\
\hline 6 & US-35S south of CR-300 S \\
\hline 7 & SR-39S south of CR-250 S \\
\hline 8 & SR-2W west of CR-500 W \\
\hline
\end{tabular}

Step 2: Enter the names of all external stations and the corresponding 2-way annual average daily traffic.

Cells A7 to A16 can accept numbers or short names for the external stations, such as "SR26W". Cells B7 to B16 need the ADT values for the corresponding external station. (See Table 3 below.)

Table 3. La Porte External Station Daily Counts

\begin{tabular}{|l|r|r|r|r|r|r|r|r|}
\hline & Johnson & US35 N & SR39 N & SR2 E & SR4 E & US35 S & SR39 S & SR2 W \\
\hline AADT & 8252 & 10376 & 7030 & 11826 & 5898 & 10534 & 3180 & 8646 \\
\hline
\end{tabular}

The number of rows you use beginning with worksheet Row 7 must match the numerical value you entered in Cell A3. For LaPorte, 8 rows (Rows 7-14) are used. Any entries in Rows 15-16 will be ignored. See the screen capture in Figure 3. 


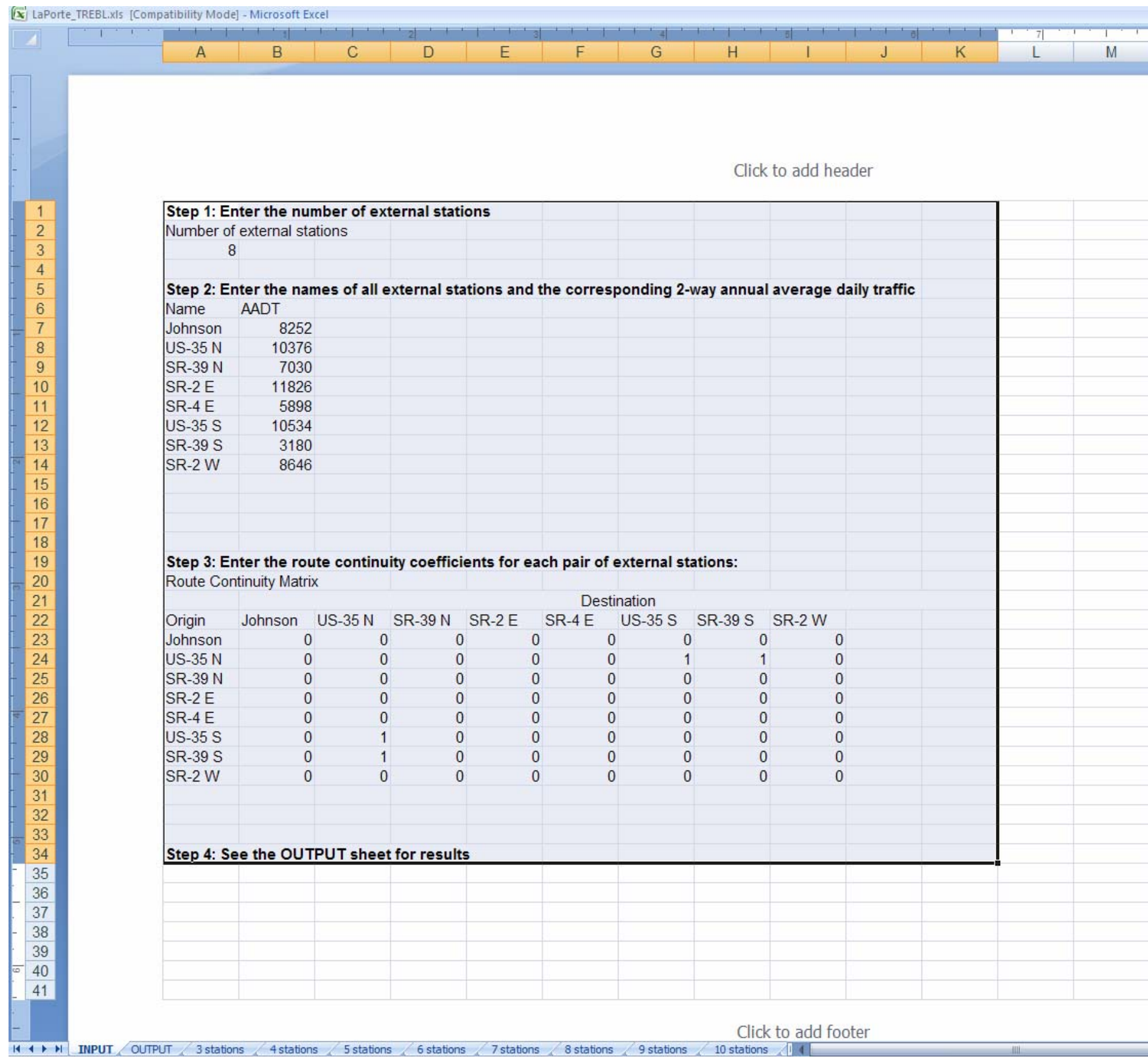

Figure 3. TREBL screen capture for LaPorte example

Step 3: Enter the route continuity coefficients for each pair of external stations.

The external station names entered in Cells A7 to A14 for LaPorte are repeated in Cells A23 to A30 and Cells B22 to I22 automatically. All the entries in the matrix bounded by these row and column headings should be zero, except for those entries that indicate a strong connection between pairs of external stations. For example, if the analyst thinks that more than "a fair share" of the vehicles that enter the study area at US35S (Sta. 6) and US39S (Sta. 7) will exit via 
US35N (Sta. 2), "1" should be entered as shown in Table 4. Note that the "1" entries should probably be symmetric for a day-long analysis. The analyst may want to experiment with this step. Hint: If a bypass is proposed to connect two external stations in particular, try using a pair of " 1 " entries to connect that O-D pair in both directions. This is likely to provide an upper bound on the estimated traffic between the two stations.

Table 4. Route Continuity Matrix for LaPorte Study Area

Destination

$\begin{array}{lrrrrrrrr}\text { Origin } & \text { Johnson } & \text { US-35 N } & \text { SR-39 N } & \text { SR-2 E } & \text { SR-4 E } & \text { US-35 S } & \text { SR-39 S } & \text { SR-2 W } \\ \text { Johnson } & 0 & 0 & 0 & 0 & 0 & 0 & 0 & 0 \\ \text { US-35 N } & 0 & 0 & 0 & 0 & 0 & 1 & 1 & 0 \\ \text { SR-39 N } & 0 & 0 & 0 & 0 & 0 & 0 & 0 & 0 \\ \text { SR-2 E } & 0 & 0 & 0 & 0 & 0 & 0 & 0 & 0 \\ \text { SR-4 E } & 0 & 0 & 0 & 0 & 0 & 0 & 0 & 0 \\ \text { US-35 S } & 0 & 1 & 0 & 0 & 0 & 0 & 0 & 0 \\ \text { SR-39 S } & 0 & 1 & 0 & 0 & 0 & 0 & 0 & 0 \\ \text { SR-2 W } & 0 & 0 & 0 & 0 & 0 & 0 & 0 & 0\end{array}$

\section{Step 4: See the OUTPUT sheet for results.}

As soon as Step 3 is completed, the output appears on the OUTPUT worksheet. See Table 5.

Table 5. La Porte EE and EI/IE Trip Distribution using TREBL

Destination

$\begin{array}{lrrrrrrrr}\text { Origins } & \text { Johnson } & \text { US-35 N } & \text { SR-39 N } & \text { SR-2 E } & \text { SR-4 E } & \text { US-35 S } & \text { SR-39 S } & \text { SR-2 W } \\ \text { Johnson } & 3239 & 147 & 114 & 177 & 100 & 152 & 63 & 134 \\ \text { US-35 N } & 147 & 3647 & 130 & 202 & 113 & 564 & 232 & 153 \\ \text { SR-39 N } & 114 & 130 & 2721 & 156 & 87 & 134 & 55 & 118 \\ \text { SR-2 E } & 177 & 202 & 156 & 4759 & 137 & 209 & 88 & 184 \\ \text { SR-4 E } & 100 & 113 & 87 & 137 & 2243 & 118 & 47 & 104 \\ \text { US-35 S } & 152 & 564 & 134 & 209 & 118 & 3858 & 75 & 158 \\ \text { SR-39 S } & 63 & 232 & 55 & 88 & 47 & 75 & 965 & 66 \\ \text { SR-2 W } & 134 & 153 & 118 & 184 & 104 & 158 & 66 & 3406\end{array}$

In Table 5, the diagonal entries for external-internal (EI) and internal-external (IE) trips have the largest values. This is typical for all but very small cities or towns. Off the diagonal, the largest EE (external-external or through) trip values are 564 for US35S to US35N and 564 for US35N to US35S. The analyst should check the O-D matrix for reasonableness.

\section{Reference}

Martchouk, Maria and Jon D. Fricker, “Origin-Destination Tools for District Offices”, Draft Final Report, Publication No. FHWA/IN/JTRP-2008/1, SPR-3095, October 2008 